Министерство сельского хозяйства Российской Федерации Федеральное государственное образовательное учреждение высшего образования «РОССИЙСКИЙ ГОСУДАРСТВЕННЫЙ АГРАРНЫЙ УНИВЕРСИТЕТ МСХА имени К. А.ТИМИРЯЗЕВА»

\title{
ЛАБОРАТОРНЫЙ ПРАКТИКУМ: \\ топливо и смазочные материалы
}

\section{Учебное пособие}

Рекомендовано УМО по образованию в области агроинженерии в качестве учебного пособия для студентов высших учебных заведений, обучаюшихся по направлению подготовки 35.03.06 «Агроинженерия»

2-е издание, переработанное и дополненное

Москва 2016 
УДК 662.75(075)

ББК 35.51

T 581

Рецензенты:

Варнаков В. В., д.т.н., ФГБОУ ВПО «Ульяновский государственный университет»

Орешенков А. В., д.т.н., ФАУ «25 ГосНИИ химмотологии Минобороны России»

Дидманидзе О. Н., Улюкина Е. А., Пильщиков В. Л., Пуляев Н. Н., Приваленко А. Н.

Лабораторный практикум: топливо и смазочные материалы: практикум / О. Н. Дидманидзе, Е. А. Улюкина, В. Л. Пильщиков, Н. Н. Пуляев, А. Н. Приваленко. - 2-е изд-е, перераб. и доп. - М.: ООО «УМЦ «Триада», 2016. - 154 с.

\section{ISBN 978-5-9546-0110-0}

Практикум содержит описание лабораторных работ по курсу «Топливносмазочные материалы». Настоящий практикум предназначен для студентов, осваивающих программу бакалавриата по направлению «Агроинженерия», может быть также использован студентами, обучающимися по направлениям: «Эксплуатация транспортно-технологических машин и комплексов», «Стандартизация и метрология», «Техносферная безопасность» и др. Практикум разработан в соответствии с государственными образовательными стандартами высшего профессионального образования.

ISBN 978-5-9546-0110-0

УДК 546 (076)

ББК 35.51

(C) ООО «УМЦ «Триада», 2016 


\section{ВВЕДЕНИЕ}

Подъем экономики страны связан с развитием топливно-энергетический базы, с наращиванием объема добычи нефти и повышением качества продукции, выпускаемой нефтеперерабатывающими заводами.

Для современных сельскохозяйственных тракторов, высокопроизводительных комбайнов, автомобилей повышенной грузоподъемности, самоходных машин, оснащенных высокофорсированными двигателями внутреннего сгорания, требуются высококачественное топливо, моторные, гидравлические и трансмиссионные масла, различные технические жидкости, пластичные смазки и т. п.

При эксплуатации сельскохозяйственной техники ежегодно расходуются десятки миллионов тонн нефтепродуктов, около 50 \% производимых в стране смазочных материалов. Повышение эффективности использования машиннотракторного парка и рациональное экономное применение топливно-смазочных материалов взаимосвязаны и имеют важное народнохозяйственное значение.

Эффективная эксплуатация сельскохозяйственной техники в течение установленного для нее ресурса, правильный выбор марок при использовании горючесмазочных (ГСМ) материалов с сохранением требуемых показателей их качества невозможен без знания химмотологических процессов как совокупности взаимосвязанных и упорядоченных по времени физикохимических превращений ГСМ, протекающих под воздействием различных внутренних и внешних факторов, процессов износа узлов и агрегатов, снижения надежности машин, а также методов оценки и приборов для исследования, без разработки и совершенствования технологии повышения качества топлива и смазочных материалов.

Знание теории и эксплуатационных свойств нефтепродуктов, приемов их рационального использования - важная составная часть общей подготовки инженерно-технических работников, призванных обеспечивать надежную, безотказную и долговечную работу сельскохозяйственной техники и снижать издержки на эксплуатацию огромного машинно-тракторного парка. 
С этой целью в учебных программах по специальности 190600 предусмотрено выполнение лабораторных работ, непосредственно знакомящих студентов с ассортиментом нефтепродуктов, помогающих овладеть практическими навыками определения их свойств и качественных характеристик, а также узнать особенности применения. Лабораторный практикум способствует закреплению теоретических знаний, полученных при изучении данной дисциплины, и обеспечивает получение определенных навыков в проведении самостоятельных исследований.

Предлагаемое учебное пособие служит кратким практическим руководством для самостоятельного выполнения лабораторных работ по испытанию топлив, смазочных материалов и технических жидкостей.

Авторы данного пособия выражают искреннюю благодарность А. В. Кузнецову и М. А. Кульчеву, являющихся авторами предыдущего пособия «Практикум по топливу и смазочным материалам», изданному в 1987 году. 


\section{Лабораторная работа № 1 \\ ОПРЕДЕЛЕНИЕ ТЕПЛОТЫ СГОРАНИЯ ДИЗЕЛЬНОГО ТОПЛИВА}

1.1. Цель работы: закрепить знания по оценке химического состава топлива и его горючей способности, приобрести навыки по измерению и расчету удельной теплоты сгорания дизельного топлива.

\section{2. Задачи работы:}

ознакомиться с методикой определения параметров, с измерительным оборудованием и приборами;

провести подготовку дизельного топлива и оборудования к лабораторным испытаниям;

провести измерения температур среды при сгорании дизельного топлива;

вычислить теплоту сгорания дизельного топлива по результатам измерения.

1.3. Оборудование и приборы: калориметрическая установка, калориметрическая бомба.

1.4. Объект испытания: дизельное топливо летнее и зимнее.

\section{5. Порядок выполнения работы}

Определение теплоты сгорания дизельного топлива следует проводить в соответствии с ГОСТ 21261-91 «Нефтепродукты. Метод определения высшей теплоты сгорания и вычисление низшей теплоты сгорания».

\section{Общие сведения}

В состав каждого топлива входит горючая и негорючая часть. Горючая часть представляет собой различные углеводороды и другие соединения, в которые входят углерод, водород, кислород, азот, сера. 
Негорючая часть (балласт) в жидком топливе - это вода и зола. Зола представляет собой негорючий остаток, образующийся после сгорания топлива. В основном золу составляют минеральные механические примеси, попадающие в топливо извне: частицы пыли, песка и т. д.

Топливо, которое подается в двигатель внутреннего сгорания в естественном состоянии и содержит горючую часть $(\mathrm{C}, \mathrm{H}, \mathrm{O}, \mathrm{N}, \mathrm{S})$, влагу $\mathrm{W}$ и золу А, называется рабочим топливом. Элементный состав рабочего топлива определяется уравнением

$$
\mathrm{C}^{\mathrm{p}}+\mathrm{H}^{\mathrm{p}}+\mathrm{O}^{\mathrm{p}}+\mathrm{N}^{\mathrm{p}}+\mathrm{S}^{\mathrm{p}}+\mathrm{A}^{\mathrm{p}}+\mathrm{W}^{\mathrm{p}}=100 \% .
$$

Иногда теплоту сгорания топлива пересчитывают на горючую массу, которая не содержит влаги и золы. Горючая масса топлива выражается уравнением

$$
\mathrm{C}_{\mathrm{r}}+\mathrm{H}_{\mathrm{\Gamma}}+\mathrm{O}_{\mathrm{r}}+\mathrm{N}_{\mathrm{r}}+\mathrm{S}_{\mathrm{r}}=100 \% .
$$

Тепловая ценность топлива характеризуется его удельной теплотой сгорания.

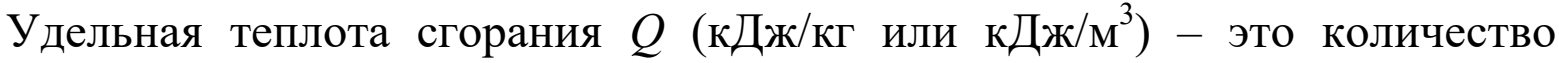
теплоты, выделяемой при полном сгорании 1 кг жидкого или твердого топлива, или $1 \mathrm{~m}^{3}$ газообразного. Показатель характеризует потенциальный запас энергии топлива и влияет на мощность двигателя. Этот показатель можно определить двумя методами: расчетным и опытным.

При расчетном методе надо знать элементный состав топлива. Согласно закону Г. И. Гесса, теплота сгорания топлива зависит только от начальных и конечных продуктов сгорания и не зависит от характера промежуточных реакций. Поэтому теплота сгорания топлива равна суммарной теплоте сгорания составляющих его элементов.

В связи с тем что топливо представляет собой не механическую смесь различных элементов, а сложное химическое соединение, при его сгорании выделяется несколько меньше теплоты. Часть ее идет на разрушение связей между молекулами. Вода, образующаяся от сгорания водорода топлива, превращается в пар, и на этот процесс затрачивается определенное количество 
теплоты. При сгорании 1 кг водорода топлива образуется 9 кг воды. Поэтому различают высшую $Q_{\text {в }}$ (с учетом тепла, выделяемого при конденсации паров воды) и низшую $Q_{\text {н }}$ (без учета тепла, выделяемого при конденсации водяных паров) удельную теплоту сгорания.

Высшая удельная теплота сгорания топлива выделяется при полном сгорании 1 кг жидкого или твердого, или 1 м $^{3}$ газообразного топлива, если образующиеся водяные пары конденсируются.

Низшая удельная теплота сгорания топлива выделяется при полном сгорании 1 кг или 1 м³ топлива без учета теплоты, затраченной на испарение влаги, образующейся при сгорании водорода, и влаги, содержащейся в топливе.

Таким образом, если в продуктах сгорания топлива вода находится в виде жидкости, то выделяется высшая теплота сгорания, если в виде пара - то низшая.

Связь между низшей и высшей теплотой выражается уравнением

$$
Q_{\mathrm{H}}=Q_{\mathrm{B}}-25 \times(9 \times \mathrm{H}+\mathrm{W}),
$$

где $25 \times(9 \times \mathrm{H}+\mathrm{W})-$ количество теплоты, которое затрачивается на парообразование воды топлива и выбрасывается с продуктами сгорания в атмосферу; 9×H - масса воды, образующаяся при сгорании единицы массы водорода; H и W - содержание в топливе водорода и воды, \%.

Коэффициент 25 указывает, что при выносе в атмосферу 1 кг пара забирает 2512 кДж, если вода находится в парообразном состоянии при охлаждении выпускных газов до $20^{\circ} \mathrm{C}$. В формуле количество теплоты 2512 разделено на 100, так как Н и W подставлены в процентах.

При определении по элементному составу пользуются формулами, предложенными Д. И. Менделеевым. Они показывают, что теплота сгорания топлива равна суммарной теплоте, выделяемой при сгорании его отдельных элементов.

Высшая удельная теплота сгорания жидкого или твердого топлива:

$Q_{\text {в }}=339 \times \mathrm{C}+\mathrm{I} 256 \times \mathrm{H}-109 \times(\mathrm{O}-\mathrm{S})$.

Низшая теплота сгорания жидкого или твердого топлива 


$$
Q_{\mathrm{H}}=339 \times \mathrm{C}+1030 \times \mathrm{H}-109 \times(\mathrm{O}-\mathrm{S})-25 \times \mathrm{W} \text {, }
$$

где коэффициенты выражают теплоту сгорания отдельных элементов, деленную на 100; C, Н, О и S - содержание различных элементов в топливе, \%.

Теплота сгорания нефтяных топлив зависит от углеводородного состава. Она снижается при увеличении соотношения С:Н в топливе.

\section{Проведение испытаний}

Для определения теплоты сгорания топлива опытным путем используют калориметрическую установку (рисунок 1).
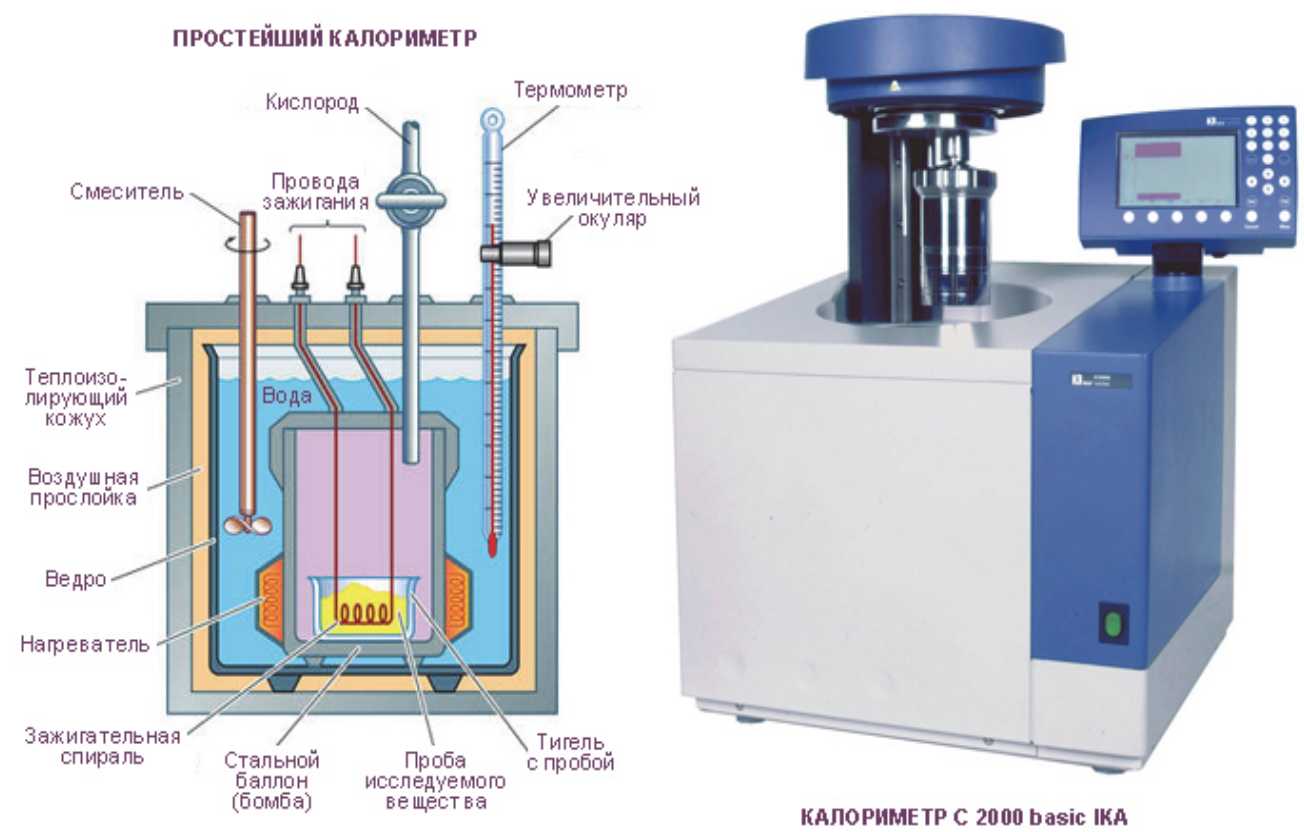

Рисунок 1 - Калориметрическая установка

Сущность метода заключается в сжигании навески испытуемого жидкого топлива в калориметрической бомбе (при постоянном объеме) в среде сжатого кислорода и определении количества теплоты, выделившейся при сгорании. Теплота сгорания стехиометрической топливовоздушной смеси (для двигателей с искровым зажиганием) всех сжиженных, газообразных и жидких топлив находится в пределах $3500 \ldots 3700$ кДЖ/м³ .

Калориметрическая бомба, изготовленная из нержавеющей стали, представляет собой толстостенный цилиндрический сосуд, закрытый крышкой 5 (рисунок 2). 


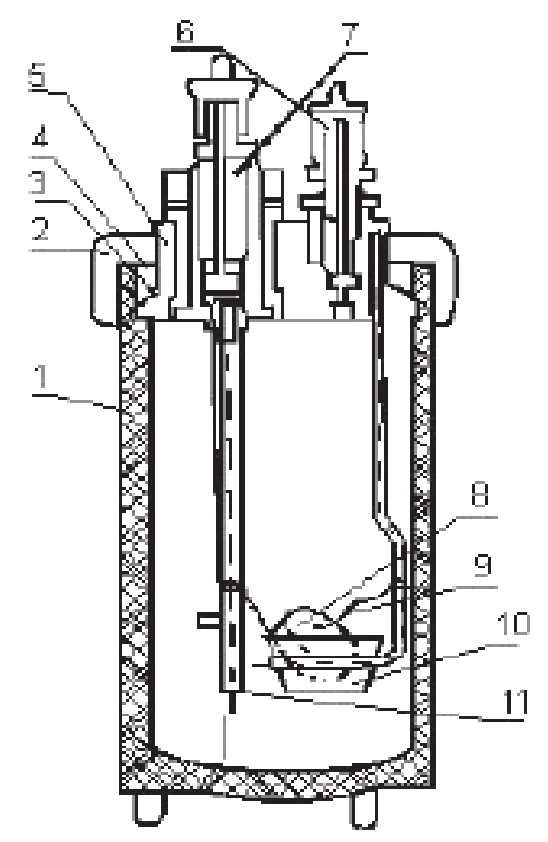

Рисунок 2 - Калориметрическая бомба: 1 - цилиндрический корпус;

2 - накидная гайка; 3 - прокладка; 4 - нажимная шайба; 5 - крышка;

6 - выходной вентиль и электрическая клемма корпуса; 7 - входной клапан и электрическая клемма изолированного электрода; 8 - таблетка для сжигания; 9 - проволока; 10 - чашка; 11 - трубка для заполнения бомбы кислородом, служащая одновременно электродом

Трубка крепится к корпусу накидной гайкой 2. В ее каналы для впуска и выпуска газов ввернуты штуцера 6,7 с колпачками. Трубка 11 предназначена для заполнения бомбы кислородом, одновременно она служит электродом. Выпускной штуцер 6 снабжен игольчатым вентилем. В крышку 5 ввернут токоведущий стержень 6 с кольцом для удержания чашки 10. Бомба самоуплотняется давлением наполняющего ее газа. При гидравлическом испытании она должна выдерживать давление 10 МПа.

Бомбу помещают в калориметр, который состоит из калориметрического сосуда и термостатирующей оболочки. Калориметрический сосуд цилиндрической формы выполнен из тонкого тщательно отполированного металлического листа. Оболочка представляет собой двустенный 
металлический кожух, защищающий калориметрический сосуд от воздушных потоков и колебаний температуры окружающей среды.

\section{6. Подготовка объекта}

В чашечку 10 наливают 0,5...0,6 г испытуемого нефтепродукта. Между электродами 11 и 6 прикрепляют запальную проволоку 9 (железную, никелиновую, константановую или медную) диаметром 0,1...0,2 мм. Ее изгибают в виде петли, в которую укрепляют полоску запальной пленки. В бомбу наливают 1 мл дистиллированной воды.

Бомбу наполняют кислородом до требуемого давления (2,9 МПа для жидкого топлива).

Бомбу устанавливают на дно калориметрического сосуда, который заливают дистиллированной водой до полного погружения бомбы. Колпачки клапанов должны выступать над водой. Температуру воды в калориметре замеряют специальным термометром (рисунок 1) с ценой деления $0,01{ }^{\circ} \mathrm{C}$. Мешалка, приводимая в действие с помощью электромотора, быстро и полностью перемешивает воду в сосуде.

\subsection{1. Методика определения}

Испытание разделяется на три периода:

начальный, который предшествует сжиганию топлива и служит для учета теплообмена калориметрической системы с окружающей средой в условиях начальной температуры испытания;

главный, в котором происходит сгорание топлива, передача выделившейся теплоты калориметрической системе и выравнивание температуры всех ее частей;

конечный, который служит для учета теплообмена калориметрической системы с окружающей средой в условиях конечной температуры испытания.

Температуру во время испытаний по термометру отсчитывают в целых и дольных частях деления шкалы. В начальном периоде после нулевого отсчета 
температуры делают пять отсчетов по шкале термометра с интервалом в 1 мин. При отсчете температур используют секундомер. При последнем отсчете замыкают цепь электрического тока, подсоединенную к клеммам бомбы. Происходит запал топлива. После этого начинается главный период, в котором отсчеты температуры проводят через каждые 0,5 мин. Интервал между последним отсчетом в начальном периоде и первым отсчетом в главном периоде является первым интервалом главного периода.

Главный период заканчивается с наступлением равномерного изменения температуры воды в калориметрическом сосуде. Интервал с равномерным изменением температуры относят к конечному периоду. За последним отсчетом главного периода следует первый полуминутный интервал конечного периода. Всего в конечном периоде проводят десять отсчетов температуры через каждые 0,5 мин.

По окончании испытания выключают электромотор, приподнимают термометр, снимают крышку калориметра, отключают провода от бомбы, вынимают бомбу из воды и вытирают ее снаружи. Затем отвинчивают колпачок с выпускного штуцера и выпускают газы, отвинчивают накидную гайку и снимают крышку. Жидкость из бомбы выливают, внутренние части бомбы промывают дистиллированной водой и тщательно вытирают.

\subsection{2. Обработка результатов измерений}

Пример записи результатов испытания дизельного топлива с ртутным термометром переменного наполнения приведен в таблице 1.

\section{Обработка результатов}

Удельную теплоту сгорания $Q_{б}$ (кДж/кг) испытуемого нефтепродукта в бомбе вычисляют по формуле

$$
Q_{\text {б }}=\frac{C \times\left(t_{2}-t_{1}+\Delta t\right)-\left(q m_{1}+Q_{\text {пл }} m_{2}\right)}{m},
$$

где $C$ - теплоемкость калориметрической системы (находятся для каждой установки опытным путем), кДж/ ${ }^{\circ}$; $t_{1}$ и $t_{2}-$ конечная и начальная температура главного 
периода, град по шкале термометра; $\Delta \mathrm{t}$ - поправка к показаниям термометра, учитывающая теплообмен калориметра с окружающей средой; $q$ - удельная теплота сгорания запальной проволоки, кДж/кг; $m_{1}$ - масса проволоки для запала, кг; $Q_{\text {пл }}$ удельная теплота сгорания пленки, кДж/кг; $m_{2}-$ масса пленки, кг; $m$ - навеска испытуемого нефтепродукта, кг.

Таблица 1 - Запись результатов испытания (пример)

\begin{tabular}{|l|c|l|c|c|c|}
\hline $\begin{array}{c}\text { Номер } \\
\text { отсчета }\end{array}$ & $\begin{array}{c}\text { Показания } \\
\text { термометра, } \\
\text { деления шкалы }\end{array}$ & Период & $\begin{array}{c}\text { Номер } \\
\text { отсчета }\end{array}$ & $\begin{array}{c}\text { Показания } \\
\text { термометра, } \\
\text { деления шкалы }\end{array}$ & Период \\
\hline 0 & 1,225 & Начальный & 16 & 2,757 & \\
\hline 1 & - & & 17 & 2,765 & \\
\hline 2 & 1,226 & & 18 & 2,771 & \\
\hline 3 & - & & 19 & 2,776 & Конечный \\
\hline 4 & 1,227 & & 20 & 2,780 & \\
\hline 5 & - & & 21 & 2,781 & \\
\hline 6 & 1,228 & & 22 & 2,782 & \\
\hline 8 & - & & 23 & 2,783 & \\
\hline 9 & 1,229 & & 25 & 2,784 & \\
\hline 10 Запал & 1,230 & Главный & 26 & 2,786 & \\
\hline 11 & 1,236 & & 27 & 2,787 & \\
\hline 12 & 2,350 & & 28 & 2,788 & \\
\hline 13 & 2,710 & & 29 & 2,789 & \\
\hline 14 & 2,730 & & 30 & 2,790 & \\
\hline 15 & 2,742 & & & & \\
\hline
\end{tabular}

Поправку $\Delta t_{\mathrm{\kappa}}$ показаниям термометра вычисляют по формуле

$$
\Delta t=\frac{v_{1}+v_{2}}{2} z_{1}+v_{2} z_{2}
$$

где $v_{1}$ и $v_{2}$ - средние скорости изменения показания термометра за один интервал в начальном и конечном периодах; $z_{1}$ - число интервалов главного периода с быстрым подъемом температуры $\left(0,3{ }^{\circ} \mathrm{C}\right.$ и более за 0,5 мин). $\mathrm{K} z_{1}$ относят первый интервал главного периода независимо от подъема температуры за этот интервал; $z_{2}$ - число интервалов главного периода, не отнесенных к $z_{1}$.

Если общее число интервалов главного периода составляет $z$, то

$$
z_{2}=z-z_{1}
$$

Удельная теплота сгорания проволоки $q$ : железной - 6690, никелиновой 3240, константановой - 3240, медной - 2510 кДж/кг. 
При подсчете высшей удельной теплоты сгорания $Q_{\text {в }}$ в найденное значение $Q_{\sigma}$ вносят поправки на теплоту образования и растворения серной и азотной кислот, получающихся из продуктов сгорания.

Высшая удельная теплота сгорания испытуемого дизельного топлива

$$
Q_{\mathrm{B}}=Q_{\sigma}-(\beta S+\alpha),
$$

где $\beta$ - коэффициент, учитывающий удельную теплоту образования серной кислоты из двуокиси серы и растворения этой кислоты в воде. Он составляет 94 кДж/кг на $1 \%$ серы, перешедшей в серную кислоту; $S$ - содержание серы в топливе, \%; $\alpha-$ коэффициент, учитывающий теплоту образования и растворения в воде азотной кислоты. Для топлива, используемого в высокооборотных дизелях, он составляет 50 кДж/кг.

Низшая удельная теплота сгорания:

$Q_{\mathrm{H}}=Q_{\mathrm{B}}-25 \times(9 \times \mathrm{H}+\mathrm{W})$.

Окончательные результаты испытания округляют с погрешностью до 40 кДж/кг.

\section{Пример расчета}

Данные для расчета: $C=14,5$ кДж ${ }^{\circ} \mathrm{C} ; t_{1}=1,230$ деления; $t_{2}=2,780$ деления; $m_{1}=0,01 \times 10^{-3}$ кг; $q=6690$ кДж/кг; $m=0,5 \times 10^{-3}$ кг; $z_{1}=3 ; z_{2}=7 ; Q_{\text {пл }}=$ 1600 кДж/кг; $m_{2}=0,03 \times 10^{-3}$ кг.

Средние скорости изменения показания термометра:

$$
\begin{aligned}
& v_{1}=\frac{(1,225-1,230)}{10}=-0,0005 ; \\
& v_{1}=\frac{(2,780-2,790)}{10}=-0,0001 .
\end{aligned}
$$

Поправка к показаниям термометра, учитывающая теплообмен с окружающей средой:

$$
\Delta t=\frac{-0,0005-0,001}{2} \times 3-0,001 \times 7=-0,0093 .
$$

Удельная теплота сгорания топлива:

$$
Q_{\sigma}=\frac{14,5 \times(2,780-1,230-0,0093)-\left(6690 \times 0,01 \times 10^{-3}+1600 \times 0,03 \times 10^{-3}\right)}{0,5 \times 10^{-3}}=44450 \text { кДж } / \text { кг. }
$$

Содержание серы в дизельном топливе равно $0,2 \%$. 
Высшая удельная теплота сгорания дизельного топлива:

$Q_{\text {в }}=44450-(94 \times 0,2+50)=44380$ кДж/кг.

Содержание водорода в дизельном топливе составляет $13 \%$, содержание воды равно нулю.

Низшая удельная теплота сгорания:

$Q_{\mathrm{H}}=44380-25 \times(9 \times 13+0)=41460$ кДж/кг.

Таблица 2 - Теплота сгорания горючих

\begin{tabular}{|l|r|}
\hline \multicolumn{1}{|c|}{ Горючее } & Теплота сгорания, Дж/кг \\
\hline Бурый уголь & $14,7 \times 10^{6} \ldots 15 \times 10^{6}$ \\
\hline Бытовой газ & $13,25 \times 10^{6}$ \\
\hline Каменный уголь & $22 \times 10^{6} \ldots 29,3 \times 10^{6}$ \\
\hline Условное топливо & $29,3 \times 10^{6}(7000 \mathrm{\kappa кал/кг)}$ \\
\hline Древесный уголь & $31 \times 10^{6}$ \\
\hline Мазут & $39,2 \times 10^{6}$ \\
\hline Нефть & $41 \times 10^{6}$ \\
\hline Керосин & $40,8 \times 10^{6}$ \\
\hline Дизельное топливо & $42,7 \times 10^{6}$ \\
\hline Бензин & $44 \times 10^{6} \ldots 42 \times 10^{6}$ \\
\hline Пропан & $47,54 \times 10^{6}$ \\
\hline Этилен & $48,0 \times 10^{6}$ \\
\hline Метан & $50,1 \times 10^{6}$ \\
\hline Водород & $120,9 \times 10^{6}$ \\
\hline
\end{tabular}

\section{Контрольные вопросы и задания}

1. Что называют теплотой сгорания топлива?

2. Как определяют теплоту сгорания топлива по элементному составу?

3. Что называют низшей и высшей удельной теплотой сгорания?

4. Как определяют теплоту сгорания жидкого топлива опытным путем? 


\section{Лабораторная работа №2 \\ ИССЛЕДОВАНИЕ СОСТАВА ПРОДУКТОВ СГОРАНИЯ АВТОМОБИЛЬНОГО БЕНЗИНА}

1.1. Цель работы: закрепить знания по оценке состава продуктов сгорания автомобильного бензина, приобрести навыки по измерению и расчету состава продуктов сгорания, коэффициента избытка воздуха.

\section{2. Задачи работы:}

ознакомиться с методикой определения состава продуктов сгорания автомобильного бензина, с измерительным оборудованием и приборами;

провести подготовку дизельного топлива и оборудования к лабораторным испытаниям;

провести измерение состава продуктов сгорания автомобильного бензина; вычислить коэффициент избытка воздуха по результатам измерения.

1.3. Оборудование и приборы: химический газоанализатор, двигатель внутреннего сгорания, спектрометрический блок.

1.4. Объект испытания: продукты сгорания автомобильного бензина.

\section{5. Порядок выполнения работы}

Определение состава продуктов сгорания автомобильного бензина следует проводить в соответствии с ГОСТ Р 52033-2003 «Автомобили с бензиновыми двигателями. Выбросы загрязняющих веществ с отработавшими газами. Нормы и методы контроля при оценке технического состояния». 


\section{Общие сведения}

По составу продуктов сгорания топлива можно судить о протекании процесса его горения.

Горение топлива - это физико-химический процесс окисления, который сопровождается выделением теплоты и повышением температуры топлива и продуктов сгорания. В основе процесса горения топлив лежат химические реакции, развивающиеся в условиях прогрессивного самоускорения, связанного с накоплением тепла, и катализирующих процесс промежуточных продуктов окисления. Процесс воспламенения и горения определяется условиями передачи тепла и вещества из зоны реакции в свежую горючую смесь, для осуществления процесса горения требуется топливо и окислитель. В двигателях внутреннего сгорания окислителем служит атмосферный воздух, содержащий 21 \% кислорода по объему. Важную роль в процессе горения играет количество подаваемого воздуха. Если воздуха подается меньше, чем требуется для полного сгорания, то образуются продукты неполного сгорания, снижаются температура и скорость горения, наблюдается дымление и уменьшается количество выделяемой теплоты.

Чрезмерное увеличение количества подаваемого воздуха также отрицательно сказывается на процессе горения, потому что оставшийся свободным кислород и значительное количество инертного азота нагреваются и уносят с собой некоторую часть теплоты. Это приводит к снижению скорости и температуры горения, перерасходу топлива. Процесс горения должен протекать так, чтобы происходило полное сгорание топлива с минимальным избытком воздуха.

К продуктам полного сгорания относятся углекислый газ $\mathrm{CO}_{2}$, водяной пар $\mathrm{H}_{2} \mathrm{O}$, сернистый газ $\mathrm{SO}_{2}$; к продуктам неполного сгорания оксид углерода СО, водород $\mathrm{H}_{2}$ и метан $\mathrm{CH}_{4}$.

Основные факторы, влияющие на скорость процесса горения: 
Соотношение топлива и окислителя, интенсивность удаления продуктов сгорания, оптимальная температура процесса и поверхность реагирования молекул.

Горение происходит во фронте пламени, имеющем определенную поверхность и ширину. Горение может происходить в ламинарном и турбулентном режиме однородных смесей.

Различают диффузионное и кинетическое горение, нормальное и детонационное горение.

Диффузионное горение имеет место, когда скорость смешения горючего и окислителя значительно ниже скорости химического превращения топлива. В этом случае скорость горения зависит от скорости физических факторов подготовки горючей смеси. При диффузионном горении скорость процесса определяется преимущественно гидродинамическими факторами и не зависит от свойств топлива.

Кинетическое горение имеет место, когда скорость процесса горения в основном зависит от химических превращений в зоне горения. При кинетическом горении скорость процесса определяется свойствами топлива, а гидродинамические факторы подготовки топлива играют меньшую роль.

Способ смесеобразования оказывает существенное влияние на процесс горения. Различают горение кинетическое, когда смесеобразование предшествует процессу горения, и диффузионное, когда оба процесса происходят одновременно. В первом случае горение не зависит от смесеобразования и определяется лишь кинетикой химических реакций, во втором случае - в основном определяется смесеобразованием.

В двигателях внутреннего сгорания с внешним смесеобразованием горение жидкого топлива кинетическое, с внутренним смесеобразованием диффузионное.

Теоретически необходимое количество воздуха для сгорания зависит от элементного состава топлива. Реакция полного горения для углекислого газа:

$$
\mathrm{C}+\mathrm{O}_{2}=\mathrm{CO}_{2}
$$


или 12 кг С +32 кг $\mathrm{O}_{2}=44$ кг $\mathrm{CO}_{2}$, тогда 1 кг $\mathrm{C}+32 / 12$ кг $\mathrm{O}_{2}=44 / 12$ кг $\mathrm{CO}_{2}$, или 1 кг $\mathrm{C}+2,67 \mathrm{O}_{2}=3,67$ кг $\mathrm{CO}_{2}$.

Для сернистого ангидрида:

$\mathrm{S}+\mathrm{O}_{2}=\mathrm{SO}_{2}$

или 32 кг $\mathrm{S}+32$ кг $0_{2}=64$ кг $\mathrm{SO}_{2}$, тогда 1 кг $\mathrm{S}+1$ кг $\mathrm{O}_{2}=2$ кг $\mathrm{SO}_{2}$.

Для водяных паров:

$2 \mathrm{H}_{2}+\mathrm{O}_{2}=2 \mathrm{H}_{2} \mathrm{O}$,

тогда 4 кг $\mathrm{H}_{2}+32$ кг $\mathrm{O}_{2}=36$ кг $\mathrm{H}_{2} \mathrm{O}$, или 1 кг $\mathrm{H}_{2}+8$ кг $\mathrm{O}_{2}=9$ кг $\mathrm{H}_{2} \mathrm{O}$.

Следовательно, для сжигания 1 кг углерода в $\mathrm{CO}_{2}$ необходимо 2,67 кг кислорода; для сжигания 1 кг серы в $\mathrm{SO}_{2}-1$ кг кислорода и для сжигания 1 кг водорода в $\mathrm{H}_{2} \mathrm{O}-8$ кг кислорода.

Таким образом, теоретически необходимое количество кислорода $L_{\text {т.к }}$ (кг) для сжигания 1 кг топлива:

$$
L_{\mathrm{T} . \mathrm{K}}=\frac{(2,67 \mathrm{C}+8 \mathrm{H}+\mathrm{S}-\mathrm{O})}{100},
$$

где $\mathrm{C}, \mathrm{H}, \mathrm{S}$ и $\mathrm{O}$ - содержание элементов в топливе, \% по массе.

Кислород входит в формулу с отрицательным знаком, потому что он входит в состав топлива и используется для горения, следовательно, на это количество его надо меньше подать с воздухом.

Количество воздуха $L_{\text {т.в }}$ (кг), теоретически необходимое для сжигания 1 кг топлива:

$$
L_{\mathrm{r} . \mathrm{B}}=\frac{(2,67 \mathrm{C}+8 \mathrm{H}+\mathrm{S}-\mathrm{O})}{23,2},
$$

Теоретически необходимое количество воздуха $L_{\mathrm{r} . \mathrm{B}}^{\prime}\left(\mathrm{M}^{3}\right)$ при его плотности $\rho=1,293$ кг $/ \mathrm{M}^{3}$ :

$$
L_{\mathrm{r} . \mathrm{B}}^{\prime}=\frac{(2,67 \mathrm{C}+8 \mathrm{H}+\mathrm{S}-\mathrm{O})}{23,2 \times 1,293}=\left(\frac{2,67 \times \mathrm{C}+8 \times \mathrm{H}+\mathrm{S}-0}{30}\right) .
$$

Действительное количество воздуха в реальных условиях сгорания топлива обычно несколько больше теоретического. 
Коэффициент избытка воздуха $\alpha$ - это отношение действительно израсходованного количества воздуха к теоретически необходимому количеству, то есть

$$
\alpha=\frac{L_{\text {д.: }}}{L_{\text {т. }}},
$$

отсюда $L_{\text {д.в }}=\alpha L_{\text {т.в. }}$.

В карбюраторных двигателях топливо сгорает при небольшом коэффициенте избытка воздуха $(\alpha=1,05 \ldots 1,15)$. В отдельные моменты работы двигателя прибегают к переобогащению $(\alpha=0,9 \ldots 0,95)$. У высокооборотных дизелей коэффициент избытка воздуха значительно выше $(\alpha=1,2 \ldots 1,4)$ и еще выше у низкооборотных $(\alpha=1,5 \ldots 1,7)$. Газовые двигатели работают $\mathrm{c}$ коэффициентом избытка воздуха $\alpha=1,03 \ldots 1,08$. Для двигателей на твердом топливе $\alpha=1,4 \ldots 2,0$.

\section{Проведение испытания}

Для определения коэффициента избытка воздуха исследуют состав продуктов сгорания. Делают это на химических газоанализаторах, которые позволяют раздельно определить в отработанных газах содержание его компонентов: углекислого газа $\mathrm{CO}_{2}$, кислорода $\mathrm{O}_{2}$ и оксида углерода $\mathrm{CO}$. Схема простейшего газоанализатора показана на рисунке 3.

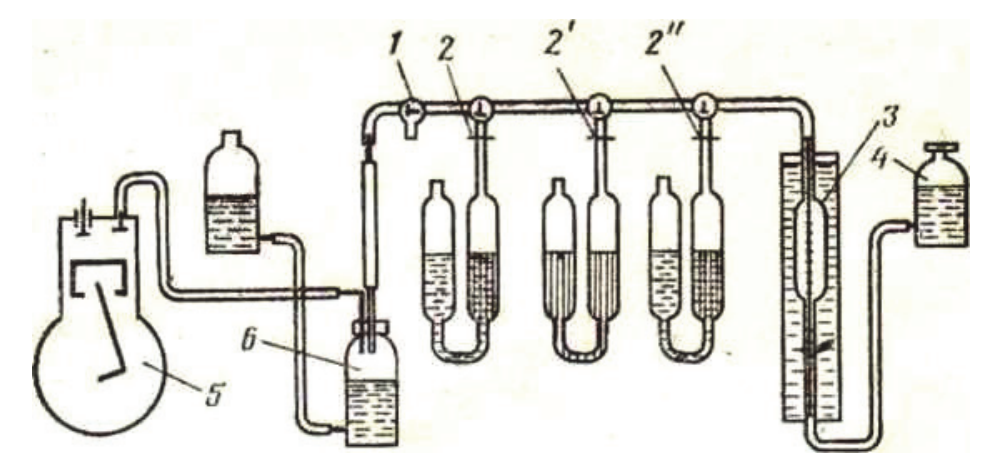

Рисунок 3 - Химический газоанализатор: 1 - запорные краны;

2, 2' и 2" - поглотительные сосуды; 3 - заборная бюретка для исследования газа; 4 - уравнительный сосуд; 5 - двигатель внутреннего сгорания;

$$
6 \text { - аспиратор }
$$


В сосуде 2" находится раствор едкого кали КОН, который активно поглощает углекислый газ; сосуд 2' заполнен щелочным раствором пирогаллола $\mathrm{C}_{6} \mathrm{H}_{3}(\mathrm{OH})_{3}$, поглощающим кислород; в сосуде 2 находится аммиачный раствор однохлористой меди для поглощения оксида углерода. Принцип действия газоанализатора заключается в избирательном поглощении растворами компонентов анализируемого газа.

\section{6. Подготовка объекта}

Двигатель внутреннего сгорания 5 устанавливают на заданный режим работы.

\subsection{1. Методика определения}

Выпускные газы по трубопроводу поступают в аспиратор 6 с насыщенным раствором поваренной соли. Нижняя бутыль аспиратора заполняется продуктами сгорания, а раствор вытесняется ими в верхнюю. Затем из аспиратора забирают газ в бюретку 3, опуская уравнительный сосуд 4 . Уровни воды в сосуде и бюретке должны быть установлены на одной высоте, соответствующей нулевому делению бюретки. Таким образом, отбирают 100 мл исследуемого газа для анализа. После этого открывают запорный кран 1 , медленно поднимают уравнительный сосуд 4 и пробу газа переводят в поглотительный сосуд с раствором едкого кали; затем, опуская уравнительный сосуд, газ снова переводят в бюретку 3. Так делают до тех пор, пока весь углекислый газ не будет поглощен щелочью. Объем газа при этом в бюретке больше не уменьшается.

\subsection{2. Обработка результатов измерений}

Аналогично определяют содержание кислорода в газе по его поглощению пирогаллолом и содержание оксида углерода по его поглощению аммиачным раствором однохлористой меди. Таким образом, в продуктах сгорания на газоанализаторе определяют содержание $\mathrm{CO}_{2}, \mathrm{O}_{2}$ и $\mathrm{CO}$ в процентах. Азот, 
содержащийся в продуктах сгорания, не поглощается ни одним из указанных растворов. Поэтому оставшийся по окончании опыта в бюретке газ является азотом, и его содержание (\%) находят аналитически:

$$
\mathrm{N}_{2}=100-\left(\mathrm{CO}_{2}+\mathrm{O}_{2}+\mathrm{CO}\right) \text {. }
$$

Если в продуктах сгорания обнаружен оксид углерода СO, то коэффициент избытка воздуха подсчитывают по формуле

$$
\alpha=\frac{1}{\left[1-\frac{3,76 \times\left(\mathrm{O}_{2}-0,5 \times \mathrm{CO}\right)}{N_{2}}\right]} .
$$

При отсутствии в продуктах сгорания оксида углерода коэффициент избытка воздуха подсчитывают по формуле

$$
\alpha=\frac{1}{\left[1-\frac{3,76 \times \mathrm{O}_{2}}{N_{2}}\right]} .
$$

В формулах (17) и (18) $\mathrm{O}_{2}, \mathrm{CO}, \mathrm{N}_{2}-$ содержание в продуктах сгорания кислорода, оксида углерода и азота, \%.

Теплоту сгорания $Q_{\text {гс }}$ горючей смеси подсчитывают по формуле

$$
Q_{\text {гс }}=\frac{Q_{\mathrm{H}}}{\left[1+\alpha L_{\text {т.в }}\right]},
$$

где $Q_{\text {н }}-$ низшая теплота сгорания топлива, кДж/кг; $\alpha$ - коэффициент избытка воздуха; $L_{\text {т.в }}$ - теоретически необходимое количество воздуха для сжигания 1 кг топлива, кг.

После обработки результатов опыта делают заключение о качестве сгорания топлива в двигателе. Представленный метод определения состава отработанных газов на химических газоанализаторах является устаревшим, он имеет высокую погрешность измерения.

Как же работают современные автомобильные газоанализаторы? В настоящее время для измерения концентрации $\mathrm{CO}, \mathrm{CH}$ и $\mathrm{CO}_{2}$ используется принцип спектрометрии. Спектрометрический блок современного газоанализатора работает по принципу частичного поглощения энергии светового потока, который проходит через газ. Молекулы любого газа представляют собой колебательную систему, которая способна поглощать 
инфракрасное излучение только в строго определенном диапазоне волн. Таким образом, если через колбу с газом пропускать стабильный инфракрасный поток, то часть его будет поглощена газом. Более того, в таком случае поглощена будет только та небольшая часть всего спектра светового потока, которую называют абсорбционным максимумом данного газа. При этом чем концентрация газа в колбе выше, тем большее будет наблюдаться поглощение.

Измерить концентрацию того или иного газа в газовой смеси путем измерения поглощения соответствующей длины волны позволяет тот факт, что разным газам соответствуют разные абсорбционные максимумы. Таким образом, определить концентрацию каждого из газов в выхлопе двигателя можно, измеряя снижение интенсивности светового потока в той части спектра, которая соответствует абсорбционному максимуму определенного газа.

Схема работы спектрометрического блока прибора изображена на рисунке 4.

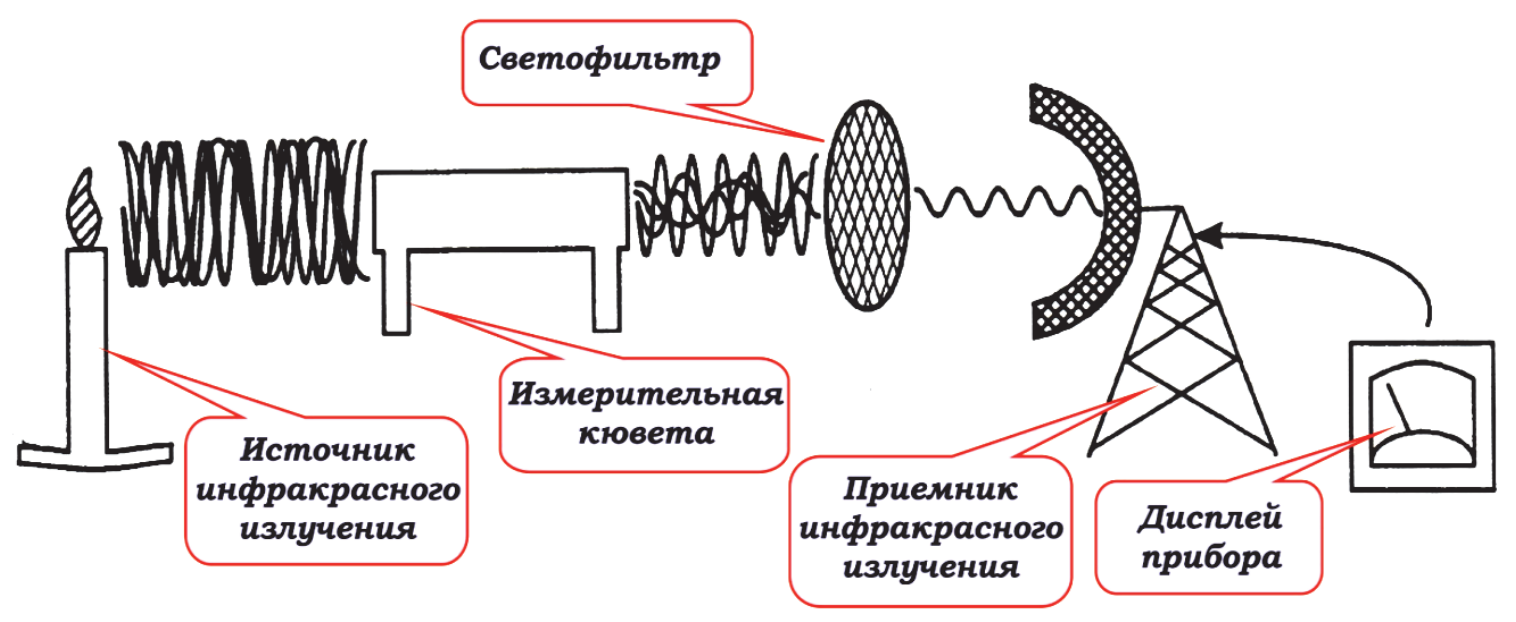

Рисунок 4 - Схема работы автомобильного газоанализатора

Через измерительную кювету, которая представляет собой трубку с закрытыми оптическим стеклом концами, прокачивают отработанные газы, предварительно отфильтрованные и очищенные от сажи и влаги. С одной стороны трубки устанавливается излучатель, который представляет собой спираль, нагреваемую электрическим током, температура которой строго 
стабилизируется на одной отметке. Такой излучатель генерирует стабильный поток инфракрасного излучения.

С другой стороны измерительной кюветы устанавливают светофильтры, которые из всего потока излучения выделяют те длины волн, которые соответствуют абсорбционным максимумам исследуемых газов. Поток после прохождения светофильтров попадает в приемник ИК-излучения, который измеряет интенсивность этого потока и преобразует ее в информацию о концентрации газов в выхлопе автомобиля.

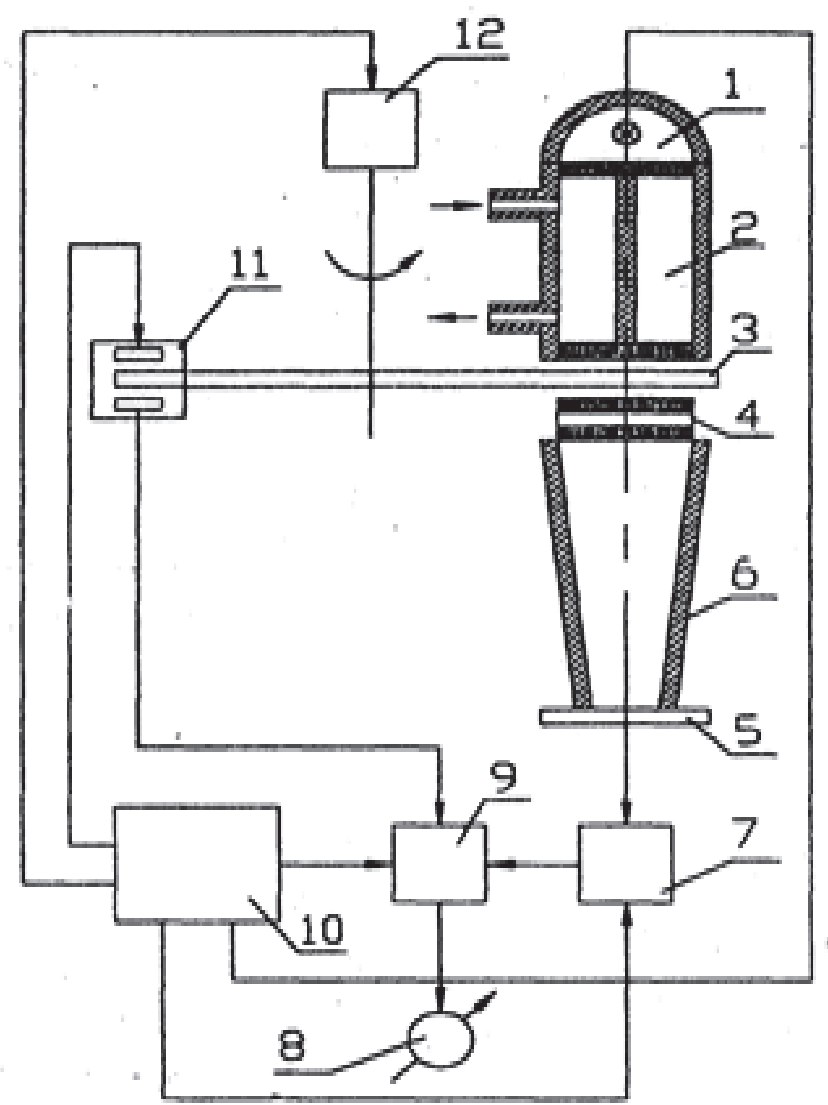

Рисунок 5 - Блок-схема газоанализатора: 1 - излучатель; 2 - измерительная кювета; 3 - обтюратор; 4 - интерференционный фильтр; 5 - фланец; 6 - приемник излучения; 7 - предварительный усилитель; 8 - показывающий прибор; 9 - блок вторичной обработки информации; 10 - блок питания с преобразователем напряжения; 11 - оптоэлектронные пары;

$$
12 \text { - электродвигатель }
$$

Поскольку данный метод применим только для измерения концентрации $\mathrm{CO}_{2}, \mathrm{CO}$ и $\mathrm{CH}$, то на следующем этапе смесь выхлопных газов из 
измерительной кюветы поступает последовательно на датчики электрохимического типа для измерения кислорода $\mathrm{O}_{2}$ и оксидов азота $\mathrm{NO}_{\mathrm{x}}$. При этом электрохимические датчики вырабатывают электрический сигнал с напряжением, пропорциональным концентрации кислорода и оксидов азота.

Таким образом, выполняется замер концентрации всех значимых газов: $\mathrm{CO}, \mathrm{CH}$ и $\mathrm{CO}_{2}$ - психрометрическим методом, $\mathrm{O}_{2}$ и $\mathrm{NO}_{\mathrm{x}}$ - электрохимическими датчиками. Обработка сигналов со спектрометрического блока и электрохимических датчиков в современном газоанализаторе выполняется при помощи микропроцессорной электронной схемы.

После обработки сигналов информация о содержании газов выводится на экран прибора: $\mathrm{CO}, \mathrm{CO}_{2}$ и $\mathrm{O}_{2}-$ в процентах, а $\mathrm{CH}$ и $\mathrm{NO}_{\mathrm{x}}-$ в ppm (partspermillion), «частей на миллион». Обозначение в ррm связано с тем, что концентрация таких газов в выхлопе крайне мала, и поэтому неудобно использовать проценты для обозначения их количества.

Соотношение между процентами и ppm можно описать следующим равенством: $1 \%=10000$ ppm.

Так, например, в отработанных газах обычного двигателя внутреннего сгорания легкового автомобиля содержание СН составляет около 0,001...0,01 \%. Сложность использования в работе таких значений и предопределило массовое распространение pрm в качестве единицы обозначения концентрации.

На сегодняшний день неплохо зарекомендовал себя в работе четырехканальный газоанализатор Инфракар М российского производства. Газоанализатор Инфракар М (рисунок 6) имеет каналы для измерения частоты вращения коленчатого вала и температуры масла (исполнение Т) двигателей автомобилей. На основании измеренных значений $\mathrm{CO}, \mathrm{CH}, \mathrm{CO}_{2}$ и $\mathrm{O}_{2}$ газоанализатор осуществляет расчет коэффициента избытка воздуха Лямбда. 


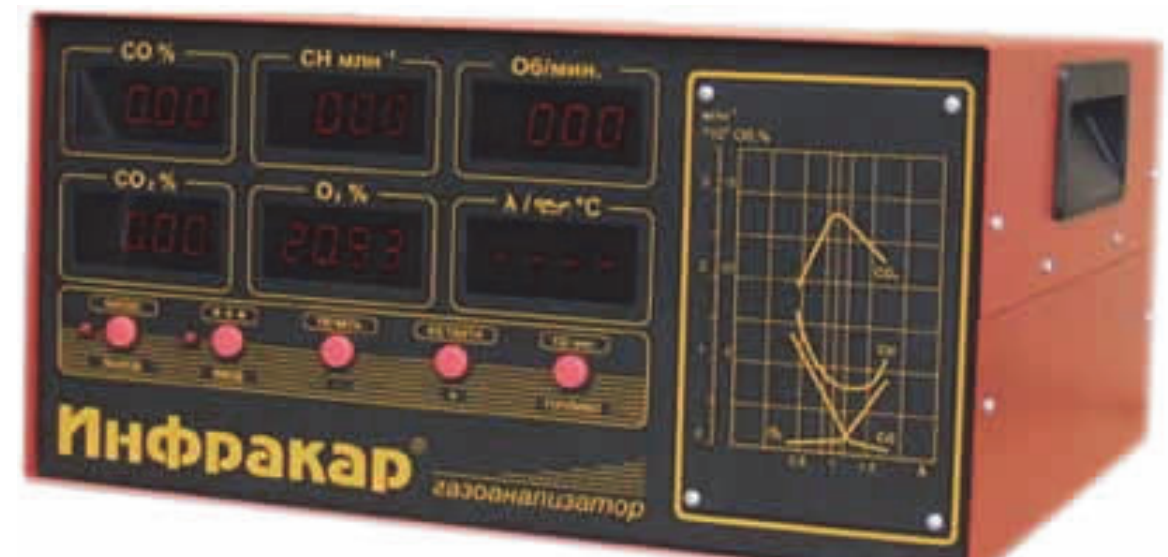

Рисунок 6 - Четырех канальный газоанализатор Инфракар М

В соответствии с требованиями ГОСТ Р 52033-2003, газоанализаторы Инфракар М делятся на приборы I и II классов точности.

Газоанализатор Инфракар М1 - прибор II класса.

Газоанализатор Инфракар M2 - прибор I класса (повышенной точности).

Газоанализатор Инфракар М, имеющий канал измерения температуры масла, обозначается буквой T.

Диапазоны измерений газоанализатора Инфракар M1:

CO: $0 \ldots 7 \%$, СН: $0 \ldots 3000$ млн $^{-1}, \mathrm{CO}_{2}: 0 \ldots 16 \%, \mathrm{O}_{2}: 0 \ldots 21 \%$, Лямбда: $0 \ldots 2$. Тахометр: 0...6000 об./мин.

Температура масла $-20 \ldots 100^{\circ} \mathrm{C}$.

Основная относительная погрешность измерений газовых каналов $\pm 6 \%$.

Приведенная погрешность измерений тахометра $\pm 2,5 \%$.

Диапазоны измерений газоанализатора Инфракар M2:

CO: $0 \ldots 5 \%, \mathrm{CH}: 0 \ldots 2000$ млн $^{-1}, \mathrm{CO}_{2}: 0 \ldots 16 \%, \mathrm{O}_{2}: 0 \ldots 21 \%$, Лямбда: $0 \ldots 2$. Тахометр: 0..6000 об./мин.

Температура масла $-20 \ldots 100^{\circ} \mathrm{C}$

Основная относительная погрешность измерений каналов $\mathrm{CO}, \mathrm{CO}_{2}, \mathrm{O}_{2}$ $\pm 4 \%$.

Основная относительная погрешность измерений канала $\mathrm{CH} \pm 5 \%$.

Приведенная погрешность измерений тахометра $\pm 2,5 \%$. 
Время прогрева - не более 30 мин при $20^{\circ} \mathrm{C}$.

Время установления показаний газоанализатора - не более $30 \mathrm{c}$.

Время установления показаний канала $\mathrm{O}_{2}-$ не более 60 c.

Питание газоанализатора - 12 / 220 В.

Потребляемая мощность - не более 30 ВА.

Средняя наработка на отказ - 10000 ч.

Срок службы - 10 лет.

Индикация показаний - светодиодная, высота цифр - 14 мм.

Масса - не более 10 кг.

Габаритные размеры $-355 \times 330 \times 180$ мм (Ш×Д×В).

Достоинства газоанализаторов Инфракар:

высокая надежность;

стабильность показаний;

малая инерционность;

автоматический слив конденсата;

автоматическая продувка нуля;

встроенный принтер с часами реального времени (исполнение 02);

связь с персональным компьютером по rs-232;

возможность подстройки чувствительности тахометра;

вычисление параметра лямбда для различных видов топлива: бензин, пропан или природный газ;

вычисление параметра СО - корректированное;

все приборы комплектуются программой для графического отображения и обработки показаний газоанализатора на персональном компьютере.

При анализе данных состава выхлопных газов можно пользоваться графиком (рисунок 7).

График представляет зависимость содержания $\mathrm{CH}, \mathrm{CO}, \mathrm{O}_{2}, \mathrm{CO}_{2}$ в выхлопных газах от соотношения воздух /топливо в смеси. Заметим, что при обогащении смеси растет содержание $\mathrm{CO}$, поэтому этот газ называется иногда 
индикатором обогащения. По аналогичным соображениям повышенное содержание кислорода - это индикатор обеднения.

Таблица 3 - Содержание вредных веществ в отработавших газах, г/км

\begin{tabular}{|l|c|c|c|r|r|r|r|}
\hline & \multicolumn{4}{|c|}{ Бензиновые двигатели } & \multicolumn{3}{|c|}{ Дизельные двигатели } \\
\cline { 2 - 8 } & $\mathrm{CO}$ & $\mathrm{CH}$ & $\mathrm{NO}_{\mathbf{x}}$ & $\begin{array}{r}\text { Tвердые } \\
\text { частицы }\end{array}$ & $\mathrm{CO}$ & $\begin{array}{r}\mathrm{CH}+ \\
\mathrm{NO}_{\mathbf{x}}\end{array}$ & $\begin{array}{r}\text { Твердые } \\
\text { частицы }\end{array}$ \\
\hline Евро II (1996) & 2,2 & 0,5 (суммарно) & - & 1 & $0,9 / 0,7^{*}$ & $0,1 / 0,08^{*}$ \\
\hline Евро III (2000) & 2,3 & 0,2 & 0,15 & - & 0,64 & 0,56 & 0,05 \\
\hline Eвро IV (2005) & 1 & 0,1 & 0,08 & - & 0,5 & 0,3 & 0,025 \\
\hline Eвро V (2010) & 1 & 0,075 & 0,06 & 0,005 & 0,5 & 0,25 & 0,005 \\
\hline
\end{tabular}

"Двигатели с непосредственным впрыском/с разделенными камерами

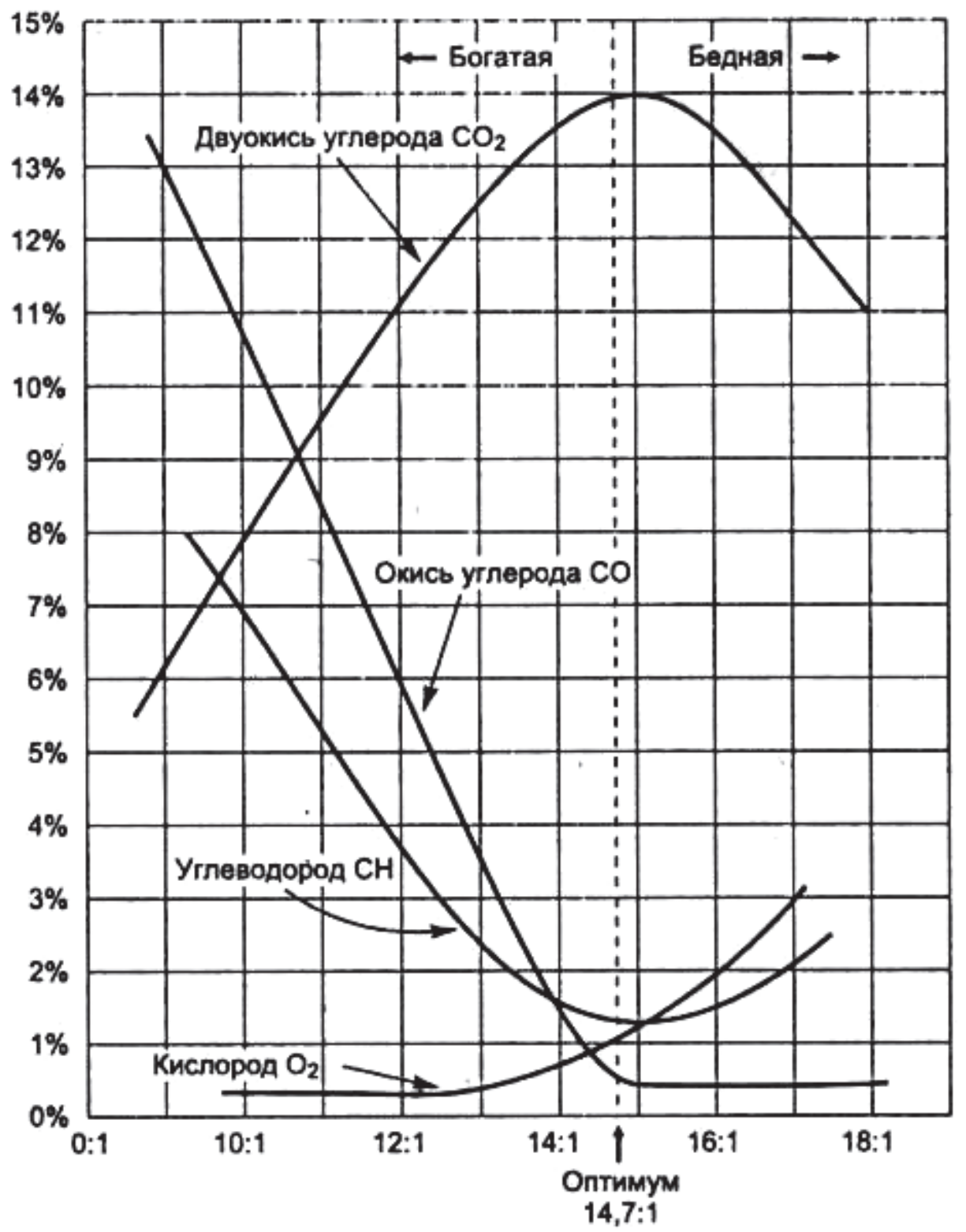

Рисунок 7 - Содержания $\mathrm{CH}, \mathrm{CO}, \mathrm{O}_{2}, \mathrm{CO}_{2}$ в выхлопных газах от соотношения воздух /топливо в смеси 


\section{Контрольные вопросы и задания}

1. Расскажите о составе отработавших газов.

2. Как подразделяются компоненты отработавших газов по воздействию на человека?

3. Какие вы знаете количественные показатели допустимого воздействия вредных веществ на окружающую среду?

4. Какие приборы используют для анализа отработавших газов?

5. В чем разница работы химического и спектрометрического газоанализаторов?

6. Какой анализ можно провести по графику состава продуктов сгорания?

7. Что называется горением топлива, какие его виды знаете? 


\section{Лабораторная работа № 3 \\ ИССЛЕДОВАНИЕ ФРАКЦИОННОГО СОСТАВА АВТОМОБИЛЬНОГО \\ БЕНЗИНА}

1.1. Цель работы: закрепить знания по качеству бензина, приобрести навыки по измерению показателей фракционного состава автомобильного бензина.

\section{2. Задачи работы:}

ознакомиться с методикой определения параметров, с измерительным оборудованием и приборами;

провести подготовку бензина и оборудования к лабораторным испытаниям;

провести измерения фракционного состава автомобильного бензина;

построить график зависимости объема и температуры при разгонке бензина;

сравнить экспериментальные данные бензина с нормативными показателями, оценить качество бензина по фракциям.

1.3. Оборудование и приборы: аппарат для определения фракционного состава, колбы для перегонки, термометр, фильтровальная бумага, мерный цилиндр, горелка, асбестовая прокладка.

1.4. Объект испытания: автомобильный бензин.

\section{5. Порядок выполнения работы}

Фракционный состав горючего определяют по ГОСТ 2177-99 «Нефтепродукты. Методы определения фракционного состава». 


\section{Общие сведения}

Бензины представляют собой смесь углеводородов, обладающих различной испаряемостью

Испаряемость - эксплуатационное свойство, характеризующее особенности и результат процесса перехода топлива из жидкого состояния в парообразное.

Испаряемость оказывает влияние на процессы образования горючей смеси в двигателе, воспламенение и горение, полноту сгорания, степень разжижения моторного масла, величину естественных потерь топлива при хранении, изменение качества топлива и экологию окружающей среды.

Испаряемость характеризует скорость и полноту перехода бензина из жидкого в парообразное состояние и определяется его химическим составом. Бензины как сложная смесь различных углеводородов выкипают не при одной постоянной температуре, а в широком диапазоне температур $\left(30 \ldots 205{ }^{\circ} \mathrm{C}\right)$. Испаряемость бензина оценивают показателями фракционного состава и летучести.

Фракционный состав показывает содержание в топливе отдельных фракций, выкипающих при перегонке топлива в заданном интервале температур в стандартных условиях испытаний.

Выражают фракционный состав в объемных и массовых процентах вскипания при нагревании до определенной температуры, либо температурой вскипания определенной фракции.

Летучесть характеризует способность бензина переходить в паровое состояние - «улетучиваться».

Фракционный состав бензина оценивают по стандартным показателям перегонки:

температура начала перегонки;

температура 10, 50, 90 \% об. вскипания;

температура конца перегонки;

объем остатка в колбе; 
объем потерь при перегонке.

Наряду с этими показателями в последнее время в стандартах на автомобильные бензины введены показатели фракционного состава.

Объем испарившегося бензина (\%) при температуре: 70, 100 и $180{ }^{\circ} \mathrm{C}$.

Для оценки влияния фракционного состава на работу двигателя фракции бензина условно делят на три части: пусковая, рабочая и концевая.

На рисунке 8 приведена кривая разгонки бензина и указаны его основные фракции.

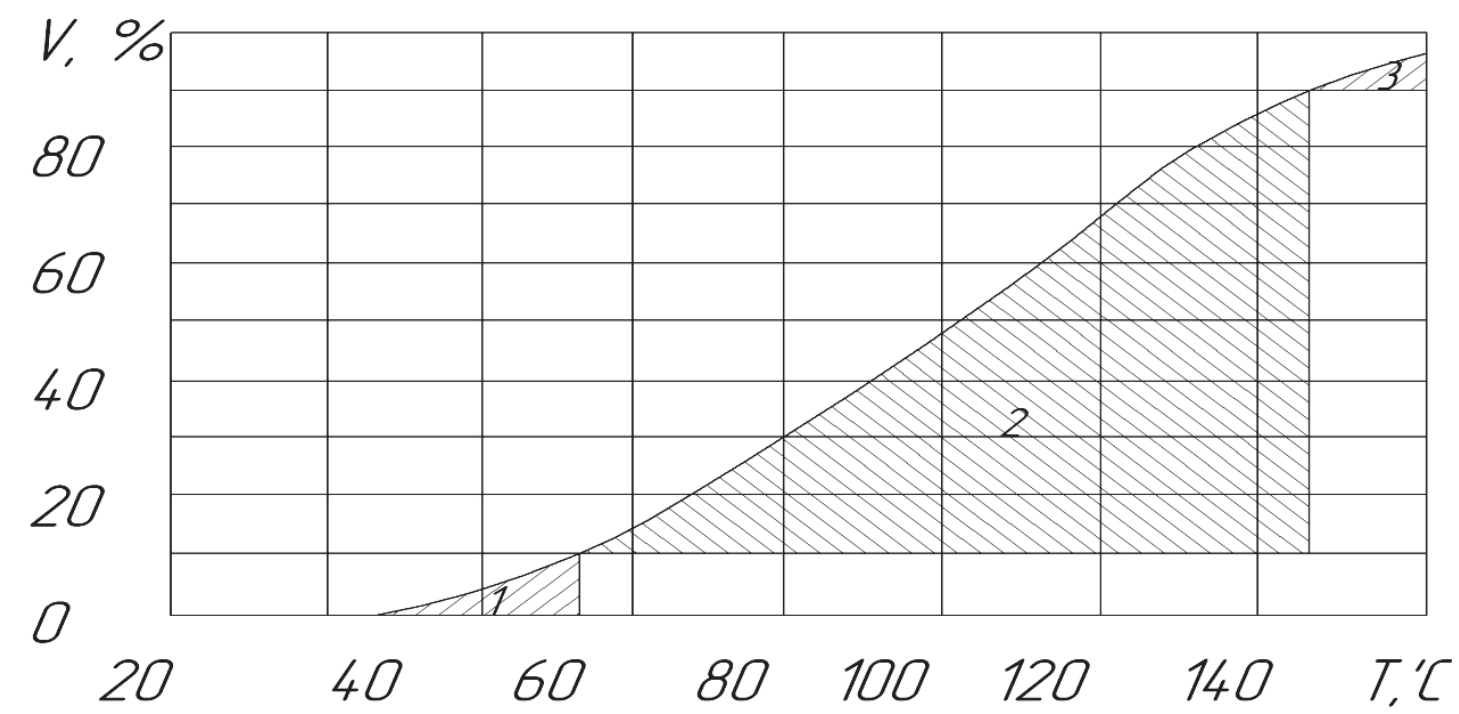

Рисунок 8 - Кривая разгонки автомобильного бензина, фракции:

1 - пусковая, 2 - рабочая, 3 - концевая

Пусковую фракцию бензина составляют самые низкокипящие углеводороды (первые 10 \% объема дистиллята). В рабочую фракцию входят дистилляты от 10 до 90 \% объема и в концевую - от 90 \% объема до конца кипения бензина. Фракционный состав бензина должен быть таким, чтобы обеспечились хороший пуск двигателя и быстрый разгон автомобиля, низкий удельный расход топлива, равномерное качественное и количественное распределение горючей смеси по цилиндрам двигателя, минимальный износ поршней и цилиндров. 
Температура начала перегонки и перегонки 10 \% (об.) характеризуют пусковые свойства бензина и его способность к образованию паровых пробок.

При пуске холодного двигателя в системе смесеобразования испаряется лишь небольшая часть бензина, его самые легкие фракции. Остальная часть бензина попадает в цилиндры двигателя при пуске в виде жидкой пленки, в которой отсутствуют легкие фракции.

Если в бензине недостаточно легких фракций, то бензиновоздушная смесь может оказаться вне пределов воспламенения и двигатель не заведется. Чем ниже температура окружающего воздуха, тем больше требуется легких фракций.

Пусковые свойства автомобильных бензинов характеризуют также температурой вскипания более тяжелой фракции - $20 \%$ и количеством бензина, выкипающим до $70{ }^{\circ} \mathrm{C}$.

Зависимость предельной температуры воздуха, при которой возможен запуска холодного двигателя $t_{\mathrm{B}}{ }^{\circ} \mathrm{C}$ ниже нуля, от температуры перегонки $20 \%$-го бензина $t_{20 \%}$ описывается формулой

$$
t_{\mathrm{B}}=\frac{1}{2} t_{20 \%}-55,0 .
$$

Если в бензине недостаточно низкокипящих фракций, то при пуске холодного двигателя часть бензина не успевает испариться и попадает в цилиндры в жидком состоянии. Горючая смесь оказывается переобедненной, она не воспламеняется от электрической искры и пуск двигателя становится невозможен. Жидкий бензин в цилиндрах смывает смазку, а в картере двигателя разжижает моторное масло. Поэтому в момент пуска и при последующем прогревании наблюдается трение деталей цилиндропоршневой группы без достаточного количества смазочного материала. Смазочного масла оказывается недостаточно для образования на поверхностях деталей прочной пленки. В этом случае создаются износы трущихся деталей двигателя, так называемые пусковые, степень которых зависит от количества неиспарившегося бензина, продолжительности пуска и прогрева двигателя и 
скорости восстановления масляной пленки на цилиндрах. Чем меньше испаряется бензина во впускной системе двигателя, продолжительнее пуск и хуже подача смазочного масла к трущимся деталям, тем значительнее пусковые износы.

Содержание низкокипящих углеводородов в современных автомобильных бензинах контролируется тремя показателями: температурой начала перегонки, температурой перегонки 10 \%-ого бензина и давлением насыщенных паров.

В соответствии с действующими стандартами, температура начала перегонки летних автомобильных бензинов должна быть не ниже $35^{\circ} \mathrm{C}$, а 10 \%го бензина должны перегоняться при температуре не выше $70{ }^{\circ} \mathrm{C}$. Температура начала перегонки зимних бензинов не нормируется, а 10 \%-го бензина должно перегоняться при температуре не выше 55 $\mathrm{C}$. Благодаря этому на летних бензинах обеспечивается пуск холодного двигателя при температуре окружающего воздуха выше $-10{ }^{\circ} \mathrm{C}$, в летний период не образуется паровых пробок. Применяя зимние бензины, можно пустить холодный двигатель при температуре воздуха $-26 . . .-28{ }^{\circ} \mathrm{C}$. Появление паровых пробок при этих условиях практически исключено.

Температура перегонки 50 \%-ной фракции бензина (рабочая фракция) характеризует скорость прогрева, устойчивость его работы на малых оборотах и приемистость. Если температура перегонки 50 \%-ной фракции высока, то испарение происходит неполно и с небольшой скоростью; горючая смесь получается обедненной, прогрев двигателя затягивается, двигатель на малых оборотах работает неустойчиво, а приемистость его ухудшается.

Приемистость двигателя предопределяет динамические качества машины, ее способность преодолевать подъемы без переключения передачи и небольшую длину разгона. За 100 \% динамичности условно принята динамичность автомобиля при работе двигателя на бензине с $t_{50 \%}=90{ }^{\circ} \mathrm{C}$. По мере повышения этой температуры динамичность автомобиля падает и при применении бензина с $t_{50 \%}=150 \stackrel{\circ}{\mathrm{C}}$ составляет всего $50 \%$. Увеличение 
температур вскипания 50 \% (об.) и конца кипения снижает скорость набора оборотов двигателя и, соответственно, мощности.

Чем легче фракционный состав и ниже температура перегонки 50 \%-го бензина, тем скорее прогревается двигатель. Бензин с низкой температурой перегонки 50 \%-го быстрее испаряется во впускном трубопроводе, наполнение цилиндра горючей смесью улучшается, мощность двигателя возрастает. При низкой температуре окружающего воздуха необходимо применять бензины с низкой температурой перегонки 50 \%-го топлива.

Приемистость - это свойство двигателя в прогретом состоянии под нагрузкой быстро переходить с малой частоты вращения к большей при резком открытии дроссельной заслонки. Для обеспечения хорошей приемистости двигателя нужно, чтобы цилиндры двигателя в момент дросселирования наполнялись богатой горючей смесью. При резком открытии дроссельной заслонки во впускной трубопровод поступает большая порция холодного воздуха и жидкого бензина, что приводит к резкому ухудшению условий парообразования из-за недостатка теплоты для полного испарения топлива.

Если бензин обладает высокой температурой перегонки 50 \%-го топлива, то некоторая часть высококипящих углеводородов, составляющих рабочую фракцию топлива, в системе питания не испаряется. В этом случае горючая смесь обеднена и двигатель не развивает более высокой частоты вращения коленчатого вала и даже может остановиться.

Для восстановления теплового режима системы питания двигателя требуется некоторое время. Тепловое равновесие устанавливается тем быстрее, чем лучше идет процесс испарения и смесеобразования, чем больше в бензине низкокипящих углеводородов. Следовательно, приемистость двигателя во многом зависит от температуры перегонки 50 \%-го бензина. С понижением этой температуры приемистость улучшается и время разгона автомобиля сокращается. Оптимальный разгон автомобиля наблюдается при такой испаряемости бензина, при которой создается горючая смесь из воздуха и паров топлива в соотношении 12:1. 
Если испаряемость бензина хуже, а значит выше температура перегонки 50 \%-го топлива, то образуется бедная смесь и время разгона автомобиля увеличивается. Температура перегонки 50 \%-го летнего бензина должна быть не более $115{ }^{\circ} \mathrm{C}$, зимнего - не более $100{ }^{\circ} \mathrm{C}$. При таких температурах обеспечиваются быстрый прогрев и хорошая приемистость двигателя во время эксплуатации автомобиля.

Температуры перегонки 90 \%-ной фракции (концевая фракция) и температура конца кипения характеризуют наличие в бензине тяжелых фракций, которые не успевают испариться во впускном трубопроводе и испаряются в цилиндрах двигателя. Если тяжелых фракций много и температура их кипения высока, то они останутся в жидком состоянии. В результате этого мощность двигателя упадет, повысится удельный расход топлива и увеличатся рабочие износы двигателя вследствие смывания масла и разжижения его топливом.

При использовании бензинов с высокой температурой конца кипения повышаются износ двигателя, количество отложений на деталях двигателя и увеличивается расход топлива.

Температура перегонки 90 \%-го топлива для летнего автомобильного бензина должна быть не выше $180{ }^{\circ} \mathrm{C}$, зимнего - не выше $160{ }^{\circ} \mathrm{C}$. Конец кипения летнего бензина должен быть не выше $195^{\circ} \mathrm{C}$, зимнего - не выше $185^{\circ} \mathrm{C}$.

Объем остатка в колбе (количество не испарившегося при перегонке бензина) характеризует наличие в бензине тяжелых, трудно испаряемых углеводородов и примесей, которые оказывают вредное влияние на работу двигателя. Как правило, эти остатки, попадая в двигатель, полностью не сгорают и увеличивают удельный расход топлива и рабочие износы двигателя.

Объем потерь при перегонке характеризует склонность бензина к испарению при транспортировании и хранении. Повышенные потери при перегонке свидетельствуют о наличии особо легких фракций в бензине, которые будут интенсивно испаряться при транспортировании и хранении, особенно в жаркое время года. 


\section{Проведение испытаний}

Фракционный состав горючего определяют по ГОСТ 2177-99 «Нефтепродукты. Методы определения фракционного состава». Данный стандарт представляет собой полный аутентичный текст международного стандарта ИСО 3405-88 «Нефтепродукты. Определение фракционного состава» с дополнительными требованиями, отражающими потребности экономики страны.

Определение фракционного состава автомобильных бензинов, авиационных бензинов, авиационных топлив для турбореактивных двигателей, растворителей с установленной точкой кипения, нафты, уайт-спирита, керосина, газойлей, дистиллятных жидких топлив и аналогичных нефтепродуктов проводится по методу А ГОСТ 2177-99.

Сущность метода заключается в перегонке (постепенном испарении) 100 $\mathrm{cm}^{3}$ испытуемого топлива и проведении постоянных наблюдений за показаниями термометра и объемами конденсата.

При определении фракционного состава топлив определяются различные характерные точки.

При определении фракционного состава могут использоваться стандартные приборы с нагревом газовой горелкой или с использованием электрического нагревателя (рисунки 9, 10).

Помимо стандартных аппаратов 1-го и 2-го типов допускается использовать и другие типы аппаратов, в том числе автоматические, обеспечивающие получение результатов в соответствии с заданной ГОСТ 217799 точностью метода. 


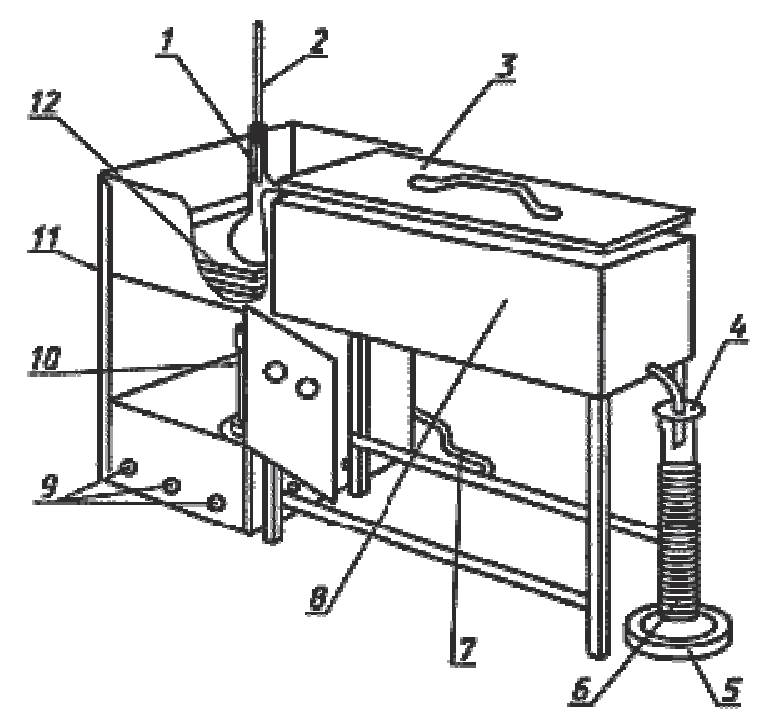

Рисунок 9 - Аппарат 1-го типа (ЛРН) (с применением газовой горелки): 1 - колба для перегонки; 2 - термометр; 3 - крышка бани;

4 - фильтровальная бумага; 5 - подставка; 6 - мерный цилиндр; 7 - газопровод; 8 - охлаждающая баня; 9 - вентиляционные отверстия; 10 - горелка; 11 - кожух; 12 - асбестовая прокладка

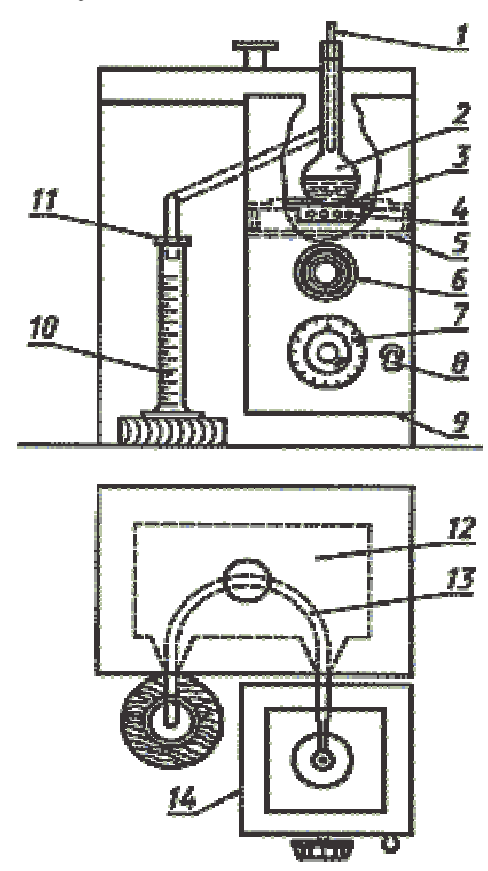

Рисунок 10 - Аппарат 2-го типа (АРНС) (с применением электрического нагревателя): 1 - термометр; 2 - колба для перегонки;

3 - асбестовая прокладка; 4 - электрический нагревательный элемент;

5 - подставка; 6 - ручка для регулирования положения колбы; 7 - диск для регулирования нагрева; 8 - выключатель; 9 - открытое дно кожуха;

10 - мерный цилиндр; 11 - фильтровальная бумага; 12 - охлаждающая баня; 13 - трубка холодильника; 14 - кожух 
В настоящее время производителями предлагаются разнообразные модели аппаратов для определения фракционного состава. Наиболее распространены аппараты ЛРН с нагревом газовой горелкой и аппараты АРНС с электрическим нагревателем (рисунок 11-14). Аппараты ЛРН являются устаревшей моделью и в настоящее время не выпускаются.

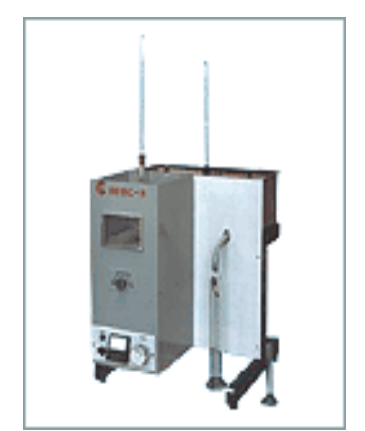

\section{Технические данные:}

Бесступенчатый регулятор мощности нагрева

Регулятор высоты стола для размещения колбы с пробой

Регулируемые опоры

Объем охлаждающей бани -8 л

Габаритные размеры $-400 \times 490 \times 400$ мм

Электробезопасная система нагрева

Мощность нагревательного элемента - 1000 Вт

Питание - переменный однофазный ток напряжением 220 В

Потребляемая мощность - не более 1,5 кВт

Рисунок 11 - Аппарат для определения фракционного состава АРНС-1э

\section{Технические данные:}

Бесступенчатый регулятор мощности нагрева

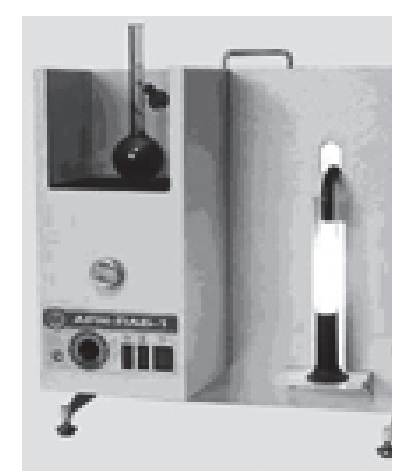

Регулятор высоты стола для размещения колбы с пробой

Регулируемые опоры

Цанговый зажим для перегонной колбы, исключающий потери на испарение и поломку колбы при установке-снятии из аппарата

Подсветка приемного (мерного) цилиндра

Перемещающаяся по высоте подставка для приемного цилиндра

Габаритные размеры $-480 \times 380 \times 530$ мм

Электробезопасная система нагрева

Мощность нагревательного элемента - 700 Вт

Питание - переменный однофазный ток напряжением 220 В

Потребляемая мощность - не более 800 Вт

Рисунок 12 - Аппарат для определения фракционного состава АРН-ЛАБ- 1 


\section{Технические данные:}

Ступенчатая ручная и автоматическая регулировка мощности нагрева Электронный цифровой измеритель температуры с погрешностью \pm $0,4{ }^{\circ} \mathrm{C}$

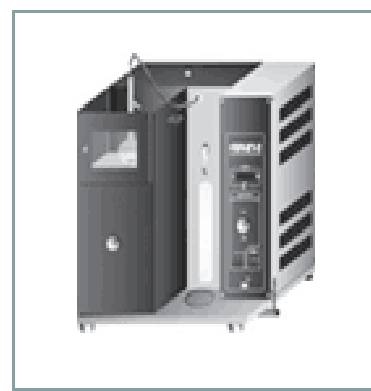

Охлаждающая баня на основе элементов Пельтье, обеспечивает поддержание температуры в пределах от 0 до $60{ }^{\circ} \mathrm{C}$, с погрешностью $\pm 0,5^{\circ} \mathrm{C}$

Регулятор высоты стола для размещения колбы с пробой. Цанговый зажим для перегонной колбы, исключающий потери на испарение и поломку колбы при установке-снятии из аппарата

Подсветка приемного (мерного) цилиндра

Цифровой интерфейс RS-485 или RS-232

Габаритные размеры - 525×525×400 мм

Электробезопасная система нагрева

Мощность нагревательного элемента - 1000 ВТ

Питание - переменный однофазный ток напряжением 220 В

Потребляемая мощность - не более 1200 Вт

Рисунок 13 - Аппарат для определения фракционного состава АРНП-2

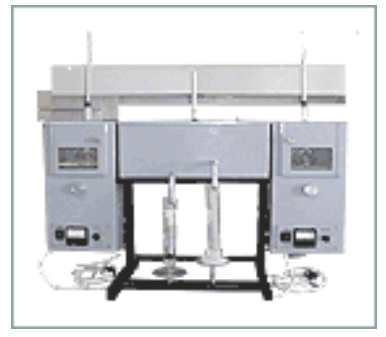

Технические данные:

Бесступенчатый регулятор мощности нагрева

Регулятор высоты стола для размещения колбы с пробой

Два нагревательных блока от аппарата АРНС-1э

Одновременный анализ двух проб топлива

Габаритные размеры $-825 \times 375 \times 580$ мм

Электробезопасная система нагрева

Рисунок 14 - Аппарат для определения фракционного состава АРНПС-2

Автоматический аппарат для определения фракционного состава АРНС20, выпускаемый отечественной промышленностью, представлен на рисунке 15. 


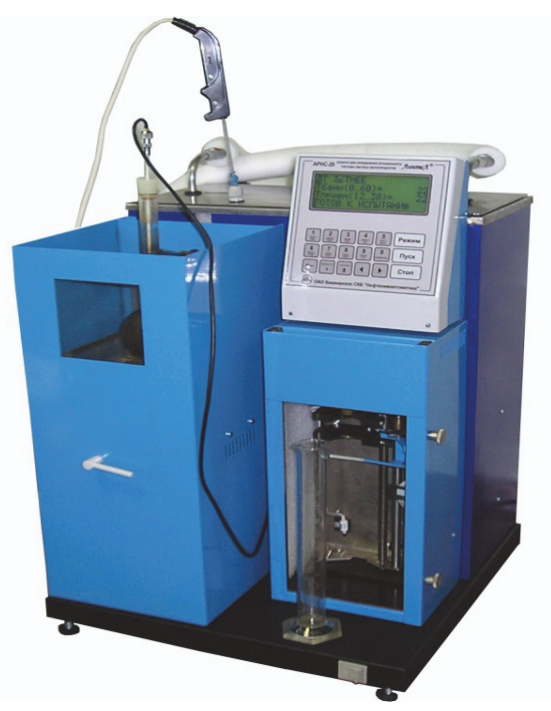

\section{Технические данные:}

Фиксируемые температуры начала и конца кипения нефтепродукта от 18 до $370^{\circ} \mathrm{C}$

Погрешность измерения температуры:

в диапазоне от 18 до $150^{\circ} \mathrm{C} \pm 0,5^{\circ} \mathrm{C}$;

в диапазоне от 150 до $300^{\circ} \mathrm{C} \pm 1,0^{\circ} \mathrm{C}$;

в диапазоне от 300 до $370{ }^{\circ} \mathrm{C} \pm 1,5^{\circ} \mathrm{C}$.

Погрешность измерения процента отгона $\pm 0,5 \%$

Пределы повторяемости и воспроизводимости соответствуют требованиям ГОСТ 2177-99

Параметры питания:

напряжение - 220 B;

потребляемая мощность - не более 1500 Вт

Габаритные размеры аппарата не более $450 \times 550 \times 600$ мм Масса - не более 20 кг

Рисунок 15 - Автоматический аппарат для определения фракционного состава АРНС-20

Перегонка топлива осуществляется в колбах для перегонки (колбы Вюрца) типа КРН по ГОСТ 25336-82. Для определения фракционного состава светлых нефтепродуктов используют колбы КРН-125 вместимостью 125 мл (рисунок 16). Для определения фракционного состава темных нефтепродуктов используют колбы КРН-250 вместимостью 250 мл.

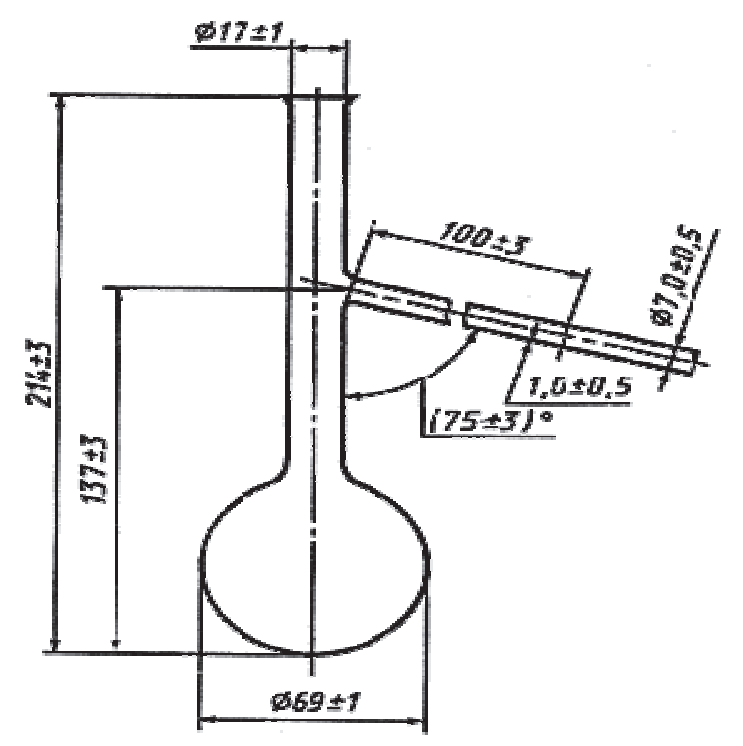

Рисунок 16 - Колба для перегонки КРН-125 


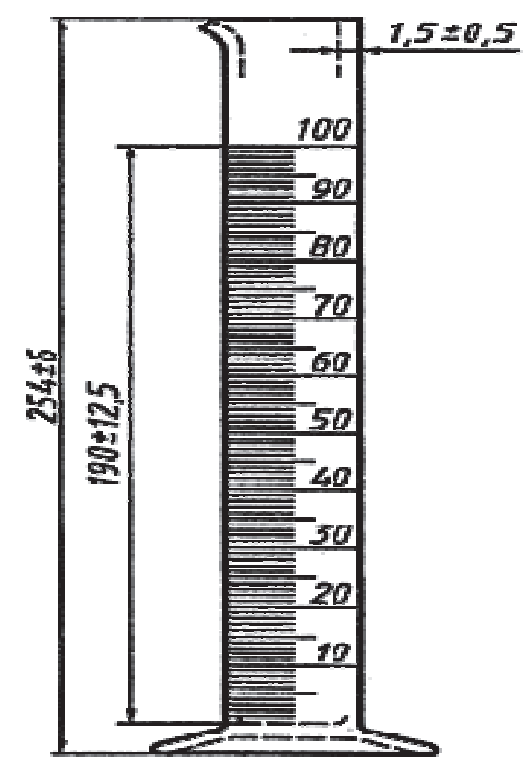

Рисунок 17 - Мерный цилиндр емкостью $100 \mathrm{~cm}^{3}$, с ценой деления $1 \mathrm{~cm}^{3}$

Для сбора конденсата используется мерный цилиндр с носиком и оплавленными краями вместимостью $100 \mathrm{~cm}^{3}$ с ценой деления $1 \mathrm{~cm}^{3}$ и градуировкой от 0 до $100 \mathrm{~cm}^{3}$ (рисунок 17). Необходимо отметить, что для определения фракционного состава не подходят мерные цилиндры вместимостью $100 \mathrm{~cm}^{3}$ изготовленные по ГОСТ 1770-74, так как эти цилиндры имеют градуировку от 10 до $100 \mathrm{~cm}^{3}$.

Для определения температуры требуется наличие двух термометров.

Низкотемпературные термометры АСТМ 7С, ТИН 4-2 имеют диапазон измерений от -2 до $+300{ }^{\circ} \mathrm{C}$ и обеспечивают анализ автомобильных, авиационных бензинов и топлива для реактивных двигателей.

Высокотемпературные термометры АСТМ 8С, ТИН 4-1 имеют диапазон измерений от -2 до $+400{ }^{\circ} \mathrm{C}$ и обеспечивают анализ дизельного топлива и темных нефтепродуктов.

На рисунке 18 показан аппарат для разгонки нефтепродуктов. Сущность метода определения фракционного состава заключается в перегонке $100 \mathrm{~cm}^{3}$ испытуемого бензина на этом аппарате при условиях, предусмотренных стандартом. 


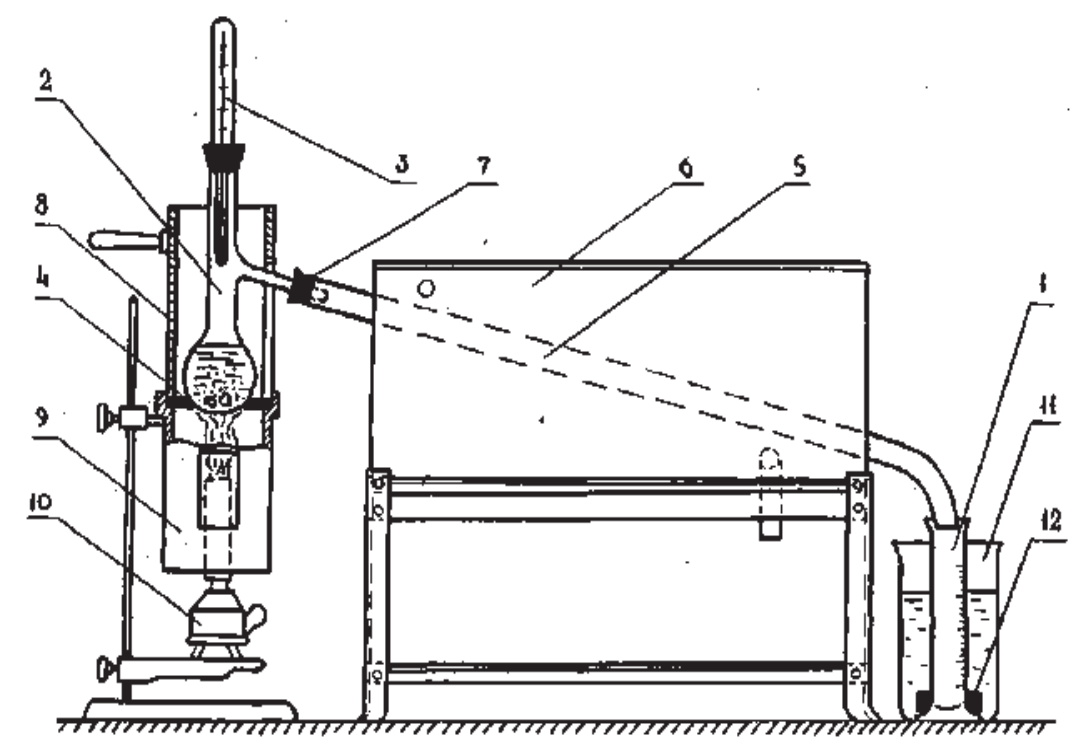

Рисунок 18 - Схема установки для разгонки нефтепродуктов:

1 - измерительный цилиндр; 2 - колба с отводной трубкой; 3 - термометр;

4 - асбестовая прокладка с фасонным отверстием; 5 - трубка;

6 - холодильник; 7 - пробка; 8 - верхний кожух; 9 - нижний кожух со смотровым окном; 10 - горелка; 11 - стакан с водой;

12 - металлический грузик

\section{6. Подготовка объекта}

Пробу бензина осторожно при минимальном перемешивании наливают в колбу. Колбу предварительно охлаждают до $13 . .18{ }^{\circ} \mathrm{C}$. Для этого ее закрывают пробкой и устанавливают в баню со льдом, где выдерживают при температуре не выше $15^{\circ} \mathrm{C}$.

Холодильник 6 заполняют так, чтобы трубка 5 холодильника была покрыта жидкостью. Температуру пробы бензина доводят до $13 \ldots 18{ }^{\circ} \mathrm{C}$. Мерным цилиндром 7 отмеряют $100 \mathrm{~cm}^{3}$ испытуемого бензина и сливают его в колбу 2 , следя за тем, чтобы бензин не попал в пароотводную трубку колбы. В горловину колбы вставляют пробку с термометром. Ось термометра должна совпадать с горловиной колбы, нижний конец капилляра - с самой высокой точкой нижней внутренней стенки пароотводной трубки. Колбу с пробой бензина помещают на подставку, трубку холодильника соединяют при помощи 
пробки с пароотводной трубкой колбы. Пароотводная трубка колбы должна входить в трубку холодильника на 25...50 мм и не касаться ее стенок.

Колбу располагают строго вертикально на асбестовой прокладке 4 нижней половины кожуха 8 . Затем закрывают колбу верхней частью кожуха. Мерный цилиндр 1, не высушивая, устанавливают под нижний конец трубки холодильника. Трубка должна входить в цилиндр не менее чем на 25 мм, но не ниже отметки $100 \mathrm{~cm}^{3}$. При перегонке бензина мерный цилиндр помещают в стеклянный сосуд с водой (баню). На цилиндр устанавливают подковообразный груз для того, чтобы он не всплывал. Уровень воды в бане для цилиндра поддерживают до отметки $100 \mathrm{~cm}^{3}$. Отверстие мерного цилиндра закрывают фильтровальной бумагой или ватой. В бане холодильника поддерживают температуру $0 \ldots 1^{\circ} \mathrm{C}$.

\subsection{1. Методика определения}

Колбу нагревают до кипения газовой горелкой или регулируемым электрическим нагревателем. Пары кипящего бензина поступают в холодильник и там конденсируются. Колбу необходимо подогреть, чтобы время от начала обогрева до падения первой капли дистиллята в цилиндр было 5... 10 мин. Температура падения первой капли считается температурой начала кипения бензина. Отмечают эту температуру и устанавливают цилиндр 1 так, чтобы конденсат стекал по стенке. Далее интенсивность нагревания поддерживают такой, чтобы скорость перегонки до получения $95 \mathrm{~cm}^{3}$ отгона была $4 \ldots 5 \mathrm{~cm}^{3} /$ мин, что примерно соответствует $20 . .25$ каплям бензина в $10 \mathrm{c}$. При этом отмечают температуры через каждые $10 \mathrm{~cm}^{3}$, бензина собранного в цилиндр. Время от образования $95 \mathrm{~cm}^{3}$ отгона до конца кипения должно составлять $3 . . .5$ мин.

Конец кипения бензина отмечают в тот момент, когда ртутный столбик термометра остановится на некоторой отметке, а затем начнет опускаться. Последний объем бензина в цилиндре фиксируют по истечении 5 мин после прекращения нагревания, когда весь бензин стек из холодильника. Остаток из 
колбы сливают в цилиндр вместимостью 10 мл, после охлаждения до $20{ }^{\circ} \mathrm{C}$ записывают его объем. Разность между 100 мл и суммой объемов дистиллята и остатка дает потери при перегонке.

\subsection{2. Обработка результатов измерений}

Если при проведении испытаний барометрическое давление выше или ниже $101,3 \times 10^{3}$ Па (760 мм рт. ст.), то вводят поправку на барометрическое давление к каждому показанию термометра. Поправку $C\left({ }^{\circ} \mathrm{C}\right)$ находят по формуле

$$
C=0,00009 \times\left(101,3 \times 10^{3}-p\right) \times\left(273+t_{0}\right)
$$

или

$$
C=0,00012 \times\left(760-p_{1}\right) \times\left(273+t_{0}\right),
$$

где $p$ и $p_{1}-$ барометрическое давление во время испытания, Па и мм рт. ст.; $t_{0}-$ показания термометра, ${ }^{\circ} \mathrm{C}$.

Скорректированную таким образом температуру округляют до $0,5^{\circ} \mathrm{C}$.

Можно пользоваться поправками на барометрическое давление, приведенными в таблице 4.

\begin{tabular}{|c|c|c|c|c|c|}
\hline \multirow{2}{*}{$\begin{array}{c}\text { Температурный } \\
\text { интервал, }{ }^{\circ} \mathrm{C}\end{array}$} & \multicolumn{2}{|c|}{$\begin{array}{c}\text { Поправки, }{ }^{\circ} \mathrm{C}, \text { на разность в } \\
\text { давлении }\end{array}$} & \multirow{2}{*}{$\begin{array}{c}\text { Температурный } \\
\text { интервал, }{ }^{\circ} \mathrm{C}\end{array}$} & \multicolumn{2}{|c|}{$\begin{array}{c}\text { Поправки, }{ }^{\circ} \mathrm{C}, \text { на разность в } \\
\text { давлении }\end{array}$} \\
\hline & $\begin{array}{c}\text { для каждого } \\
1 \text { кПа }\end{array}$ & $\begin{array}{l}\text { для каждых } \\
\text { 10мм рт. ст. }\end{array}$ & & $\begin{array}{c}\text { для каждого } \\
1 \text { кПа }\end{array}$ & $\begin{array}{l}\text { для каждых } \\
10 \text { мм } \\
\text { рт. ст. }\end{array}$ \\
\hline $10 \ldots 30$ & 0,26 & 0,35 & $110 \ldots 130$ & 0,35 & 0,47 \\
\hline $30 \ldots 50$ & 0,29 & 0,38 & $130 \ldots 150$ & 0,38 & 0,50 \\
\hline $50 \ldots 70$ & 0,30 & 0,40 & $150 \ldots 170$ & 0,39 & 0,52 \\
\hline $70 \ldots 90$ & 0,32 & 0,42 & $170 \ldots 190$ & 0,41 & 0,54 \\
\hline $90 \ldots 110$ & 0,34 & 0,45 & $190 \ldots 210$ & 0,43 & 0,57 \\
\hline
\end{tabular}

Таблица 4 - Поправки на барометрическое давление

Поправку $C$ прибавляют к показаниям термометра при давлении ниже $101,3 \times 10^{3}$ Па (760 мм рт. ст.) и вычитают при более высоком давлении.

Результаты перегонки бензина представляют в виде графика, называемого кривой разгонки. 
К недостаткам определения фракционного состава на аппарате для разгонки нефтепродуктов относятся трудности регулировки и регистрации температуры, а также наблюдения за объемом топлива. Современные приборы позволяют автоматически проводить измерения.

Определение фракционного состава на автоматическом анализаторе фракционного состава нефти и нефтепродуктов при атмосферном давлении (атмосферная разгонка) HerzogOptiDist (рисунок 19), ASTM D 86, ГОСТ $2177-$ 99 (А и Б), ISO EN 3405, ASTM D 850, ASTM D 1078, IP 123, IP 191, IP 195.

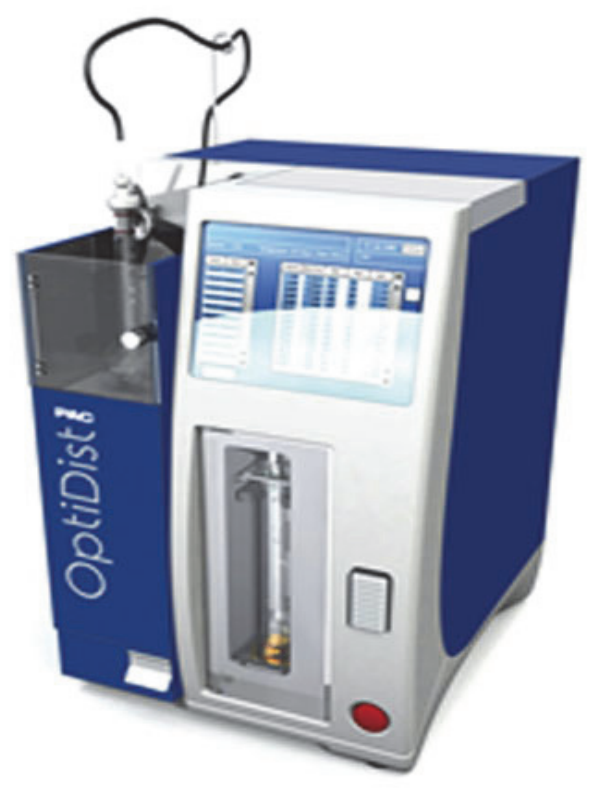

Рисунок 19 - Автоматический анализатор фракционного состава нефти и нефтепродуктов при атмосферном давлении (атмосферная разгонка) HerzogOptiDist

Анализ фракционного состава нефти, любых светлых нефтепродуктов ведется в полностью автоматическом режиме без участия лаборанта, который лишь наполняет специальный мерный цилиндр, переливает в колбу, устанавливает стеклянное оборудование в прибор и указывает группу разгонки. После программной проверки соответствия установленного оборудования выбранному продукту и правильности монтажа всех узлов, запускается полностью автоматический цикл анализа, включающий контроль температуры нагревателя, времени до начала кипения, температуры первой капли (начало 
кипения), скорости разгонки, температуры паров, конца кипения по падению температуры паров или датчику последней капли. Прибор не требует никаких предварительных тестов или настроек, оптимальные параметры предварительного нагрева и собственно анализ ведется с первой попытки в полностью автоматическом режиме в соответствии с выбранным стандартом. Автоматическая оптимизация процесса нагрева позволяет не только улучшить точностные характеристики эксперимента, но и защищает материал колбы от излишнего перегрева. Это положительно сказывается на сроке жизни дистилляционных колб и нагревателя, уменьшает риск возникновения пожара вследствие разрушения колбы во время анализа. В то же время прибор оснащен развитой системой автоматического пожаротушения с двумя многоразовыми датчиками открытого пламени, что позволяет исключить не только первичные, но и вторичные очаги возгорания, в том числе внизу нагревательного отделения. OptiDist может применяться для автоматического получения 10 \%го остатка при анализе коксуемости. Поставляется со встроенным ПК с энергонезависимой флэш-памятью, цветным широкоформатным графическим монитором с TFT-матрицей и сенсорным управлением, тремя USB-портами для подключения принтера, штрих-декодера и карты памяти, последовательным портом RS232, сетевой картой Ethernet. Программное обеспечение прибора русифицировано, новые версии поставляются бесплатно по электронной почте, смена производится самостоятельно за 5 мин.

Малоинерционный низковольтный электробезопасный нагреватель с функцией автоматической компенсации старения спирали, служит годы без замены. Конденсор может дополнительно оснащается специальным бустернагревателем, позволяющим практически мгновенный разогрев трубки при анализе сырой нефти по ГОСТ 2177-Б. Прибор оснащен встроенной герметичной системой термостатирования с охлаждающим контуром, при работе прибору не требуется никаких иных подводок или внешних приборов, кроме электропитания. Опциональный патрубок для отвода паров легколетучих углеводородов из приемного отделения для снижения риска образования 
взрывоопасной среды - при анализе сырой нефти и легких углеводородов. Датчик температуры со встроенным чипом памяти с калибровкой, автоматическое распознавание нового датчика при замене. Встроенный барометр с простой системой одноточечной калибровки по образцовому барометру-анероиду. Новейшая система оптического детектирования объема с режимом по верхнему или нижнему краю мениска, надежное определение объема «дымящихся» и двухфазных образцов (биоДТ, сырая нефть с присадками).

В журнал испытаний записывают марку и вид испытуемого бензина, требования государственного стандарта к этому бензину: давление насыщенных паров, температуры начала и конца кипения, вскипания 10 \%-го, 50 и 90 \%-го топлива, остаток и потери бензина при разгонке.

Далее строят график фракционного состава по предельно допустимым значениям в пяти характерных точках в соответствии с ГОСТ на бензин.

На основании картограммы в журнале составляют таблицу, где отмечают температуру через каждые 10 мл собранного в цилиндр дистиллята. Там же записывают количество залитого в колбу бензина, температуру начала и конца кипения бензина, остаток и потери топлива при разгонке.

Затем по полученным данным строят кривую разгонки.

После этого делают заключение о фракционном составе бензина, сравнивают результаты испытания с данными ГОСТ, определяют качество бензина, дают характеристику его пусковых свойств, устойчивости работы нагарообразующей способности и приемистости двигателя при использовании этого бензина. В заключение также указывают, будет ли при работе двигателя на испытуемом бензине наблюдаться повышенный износ деталей двигателя и не сократится ли межремонтный пробег автомобиля.

\section{Приложение}

ГОСТ Р 51866-2002 (ЕН 228-2004). Топлива моторные. Бензин неэтилированный. Технические условия [27.09.13] 


\subsection{3. Технические требования}

Физико-химические и эксплуатационные показатели бензинов приведены в таблице 5 (Измененная редакция, Изм. № 2). Таблица сокращена авторами.

\subsection{4. Требования к испаряемости}

Стандарт предусматривает производство 10 классов бензинов по испаряемости.

Предельные значения характеристик испаряемости приведены в таблице 6.

Диаграмма определения классов испаряемости бензинов приведена на рисунке 20 .

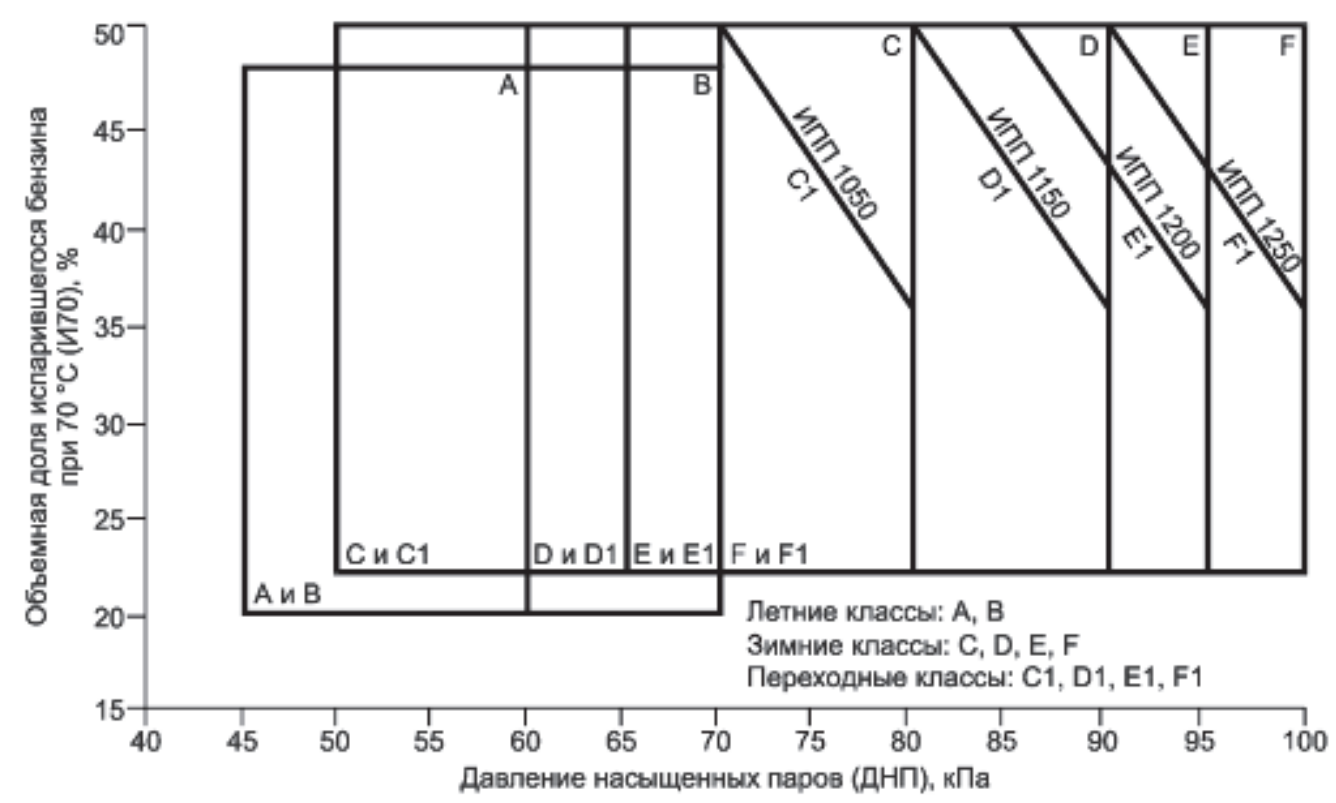

Рисунок 20 - Диаграмма определения классов испаряемости бензинов 


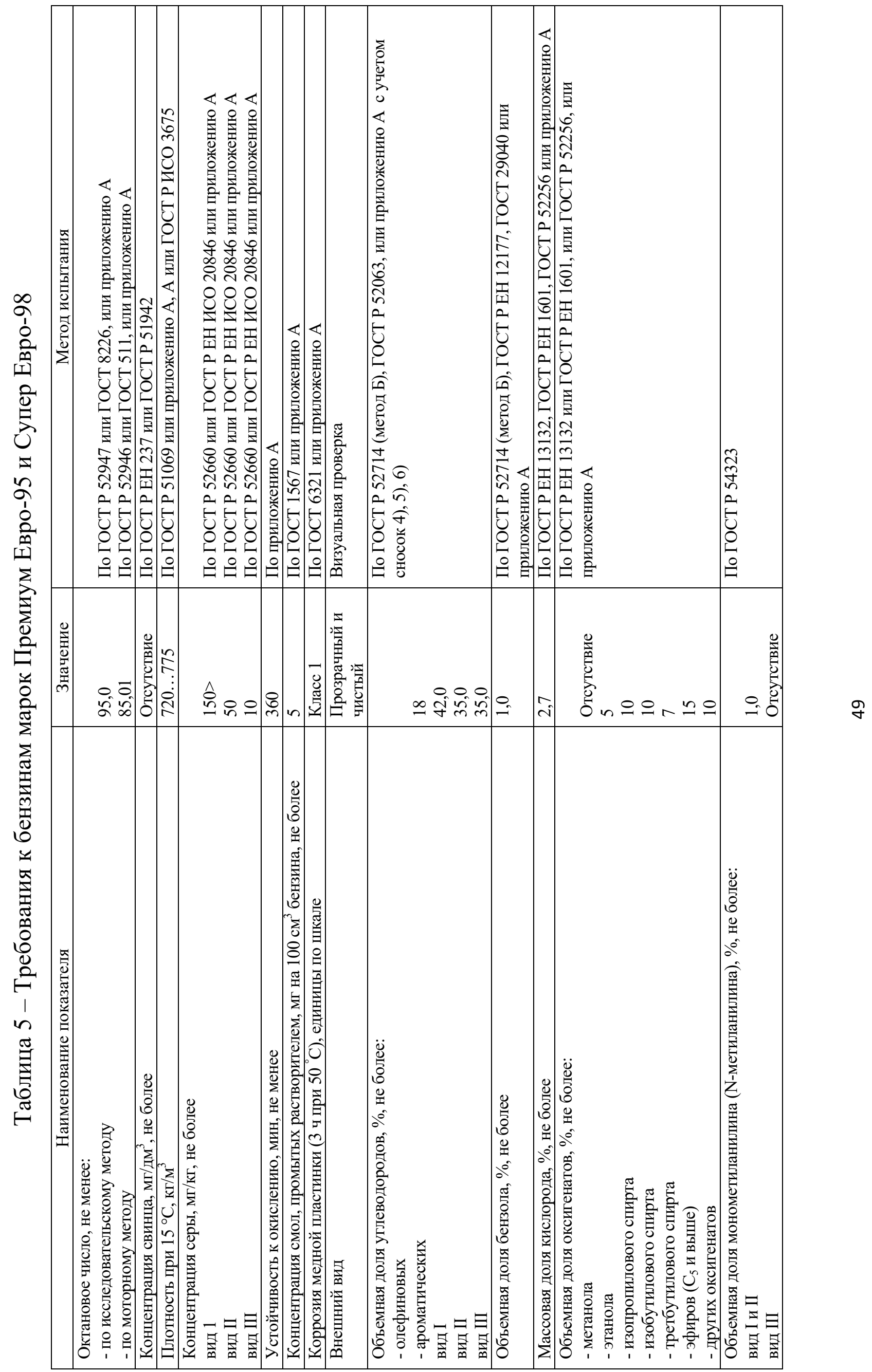




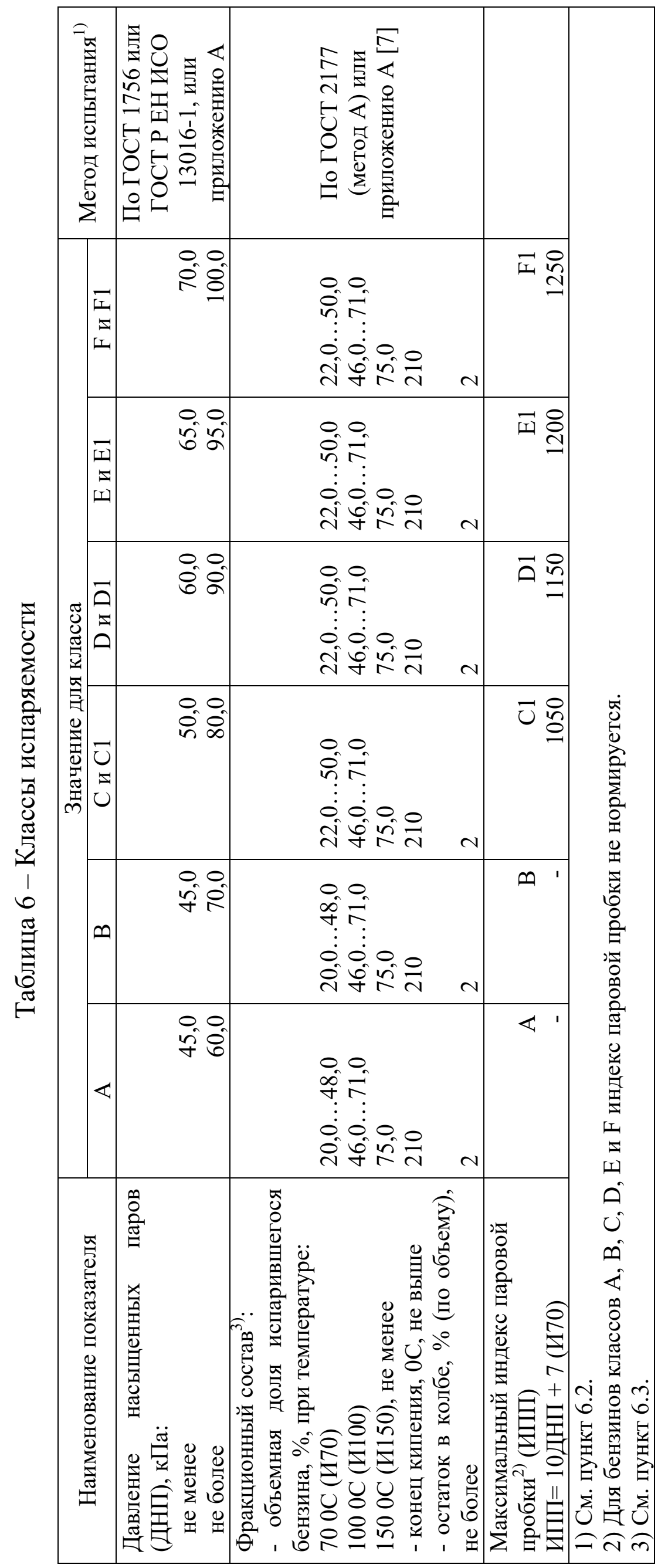




\section{Контрольные вопросы и задания}

1. Какие свойства бензинов оценивают по фракционному составу?

2. Особенность работы двигателя при сгорании пусковой, рабочей и концевой фракций бензина.

3. Назовите внешние признаки и сущность детонационного сгорания бензина?

4. Что называется октановым числом бензина?

5. Как оценивают химическую стабильность и склонность к отложениям бензинов?

6. Назовите марки бензинов для легковых и грузовых автомобилей.

7. Каковы основные характеристики бензинов с улучшенными экологическими показателями?

8. Какие используют приборы для оценки фракционного состава бензина?

9. Какие предъявляются требования к испаряемости бензинов? 


\section{Лабораторная работа № 4 \\ ОПРЕДЕЛЕНИЕ НИЗКОТЕМПЕРАТУРНЫХ СВОЙСТВ ДИЗЕЛЬНОГО \\ ТОПЛИВА}

1.1. Цель работы: закрепить знания по качеству дизельного топлива, приобрести навыки по измерению показателей низкотемпературных свойств, текучести и фильтруемости дизельного топлива.

\section{2. Задачи работы:}

ознакомиться с методикой определения параметров, с измерительным оборудованием и приборами;

провести подготовку дизельного топлива и оборудования к лабораторным испытаниям;

выполнить измерение низкотемпературных свойств дизельного топлива;

сравнить экспериментальные данные качества дизельного топлива с нормативными показателями, оценить представленные образцы дизельного топлива.

1.3. Оборудование и приборы: баня для поддержания температуры; стеклянные пробирки, муфты; термометры.

\section{4. Объект испытания: дизельные топлива.}

\section{5. Порядок выполнения работы}

Определение низкотемпературных свойств дизельного топлива следует проводить в соответствии с требованиями стандарта. Температура застывания определяется по методу Б ГОСТ 20287-91 «Нефтепродукты. Методы определения температур текучести и застывания» с дополнениями п. 4.2. ГОСТ 305-82*; температуру помутнения определяют по методу Б ГОСТ 5066-91

\footnotetext{
* Температуру застывания дизельного топлива определяют по ГОСТ 20287-91 без предварительного и последующего подогрева топлива до $50^{\circ} \mathrm{C}$.
} 
«Топлива моторные. Методы определения температуры помутнения, начала кристаллизации и кристаллизации».

\section{Общие сведения}

При положительных температурах подача дизельного топлива (далее ДТ) в камеру сгорания не создает проблем из-за отсутствия паровых пробок вследствие низкой испаряемости и вязкости.

При отрицательных температурах возникают серьезные проблемы по обеспечению текучести и фильтруемости топлив.

Прокачиваемость ДТ зависит от низкотемпературных характеристик углеводородных фракций. Низкотемпературные свойства топлив зависят от длины цепи н-парафинов и пределов их выкипания. В состав летних ДТ входят парафины с длиной цепи $\mathrm{C}_{6}-\mathrm{C}_{27}$, а в состав зимних $-\mathrm{C}_{6}-\mathrm{C}_{19}$.

Одним из важных эксплуатационных свойств дизельного топлива являются его низкотемпературные свойства. Показателями низкотемпературных свойств являются: температура помутнения, температура застывания и предельная температура фильтруемости.

Температура помутнения - температура, при которой жидкое прозрачное топливо начинает мутнеть при охлаждении вследствие образования кристаллов парафиновых углеводородов. Температура помутнения ДТ зависит от количества высокоплавких н-парафиновых углеводородов, которые резко повышают температуру помутнения. Температура помутнения также связана с выделением в топливе микрокапель воды, микрокристаллов льда и других нерастворимых веществ. При понижении температуры растворимость воды в топливе уменьшается и вода выделяется в виде микрокристаллов льда. Температура помутнения позволяет прогнозировать температурные пределы применения топлив без депрессорных присадок. Таким образом, температура помутнения характеризует прокачиваемость при низких температурах и условно определяет самую низкую температуру окружающего воздуха, при которой возможно применение топлива на технике. Введение депрессорных присадок не влияет на температуру помутнения. 
Температура застывания - это температура, при которой топливо теряет текучесть в стандартных условиях испытаний. Причиной потери текучести является образование и сращивание кристаллов углеводородов между собой в жесткую кристаллическую решетку. Температура застывания в меньшей степени характеризует поведение топлива в системе питания двигателя, а в большей степени определяет возможность заправки, транспортирования, слива и налива топлива в резервуары.

Наиболее критическим моментом в работе дизельного двигателя при низких температурах считают период пуска и прогрева на холостом ходу. На линии всасывания происходит забивка фильтра грубой очистки, что не обеспечивает подачу топлива в необходимом для работы количестве. Подача топлива прекращается при низкой температуре по причине забивки фильтра за 5..10 ${ }^{\circ} \mathrm{C}$ выше, чем температура застывания топлива. Точнее работоспособность топливной системы характеризует предельная температура фильтруемости.

Предельная температура фильтруемости - самая низкая температура, при которой данный объем топлива не протекает через стандартизованную фильтрующую установку в течение определенного времени.

При введении в топливо депрессорных присадок характеристикой работоспособности топлива является предельная температура фильтруемости.

\section{Проведение испытаний}

Температура застывания определяется по методу Б ГОСТ 20287-91 «Нефтепродукты. Методы определения температур текучести и застывания» с дополнениями п. 4.2. ГОСТ 305-82*. Сущность метода заключается в предварительном нагревании образца испытуемого топлива с последующим охлаждением его с заданной скоростью до температуры, при которой образец остается неподвижным. Указанную температуру принимают за температуру застывания.

Для определения собирается прибор, состоящий из:

\footnotetext{
* Температуру застывания дизельного топлива определяют по ГОСТ 20287-91 без предварительного и последующего подогрева топлива до $50{ }^{\circ} \mathrm{C}$.
} 
- бани для поддержания установленной температуры испытания;

- стеклянной пробирки со сферическим дном, высотой $160 \pm 10$ мм, внутренним диаметром $20 \pm 1$ мм, на наружной боковой поверхности стеклянной пробирки на расстоянии 30 мм от дна должна быть несмываемая кольцевая метка;

- стеклянной муфты с вогнутым или сферическим дном, высотой $130 \pm 10$ мм, внутренним диаметром $40 \pm 2$ мм;

- термометра типа ТИН-3, ТН-8 по ГОСТ 400, ТН-6 по ТУ 92.887017 для измерения температуры застывания;

- термометра любого типа для измерения температуры охлажденной смеси с градуировкой шкалы $1^{\circ} \mathrm{C}$.

Как правило, баня представляет собой стеклянный сосуд Дьюара с широким горлом (внутренний диаметр не менее $80 \ldots 100$ мм) ${ }^{*}$. Конструкция бани должна быть такова, чтобы можно было наклонять корпус на угол в $45^{\circ}$ и фиксировать его в данном положении.

Требуемая температура бани поддерживается с помощью холодильного устройства или охлаждающей смеси.

Оптимальным является использование в качестве охлаждающей смеси этилового спирта и твердой углекислоты.

Допускается применять полуавтоматические лабораторные аппараты, обеспечивающие проведение испытаний с точностью измерения не ниже $1{ }^{\circ} \mathrm{C}$. Имеется достаточно широкая линейка таких приборов - ЛАЗ-93М, АТЗ, ЛАЗ93М1, ЛАЗ-93М2, Кристалл-10Э, ПОНС.

Bce данные аппараты не требуют применения охлаждающей смеси, охлаждение испытуемого образца проводится при помощи полупроводниковых охлаждающих элементов Пельтье, в отдельных аппаратах требуется осуществлять охлаждение самих элементов Пельтье с помощью проточной воды (ЛАЗ-93М, ЛАЗ-93М1, КристалЛ-10Э).

\footnotetext{
* В том числе можно использовать бытовые стеклянные термостаты с диаметром горла не менее $80 \ldots 100$ мм.
} 


\section{Аппарат лабораторный для определения температуры застывания}

нефтепродуктов ЛАЗ - 93М (рисунок 21) позволяет анализировать все нефтепродукты, температура застывания которых определяется по ГОСТ 20287. Температурные режимы предварительного разогрева и охлаждения пробы поддерживаются автоматически и соответствуют требованиям ГОСТ 20287. Управление последовательностью операций осуществляется автоматически. Основной недостаток прибора - узкий диапазон определения температуры застывания (от -40 до $+10{ }^{\circ} \mathrm{C}$ ), что не позволяет анализировать дизельное топливо арктическое, низкозастывающие масла, топочные мазуты и ряд других нефтепродуктов.

\section{Технические характеристики:}

Диапазон определения температуры застывания - от $-40{ }^{\circ} \mathrm{C}$

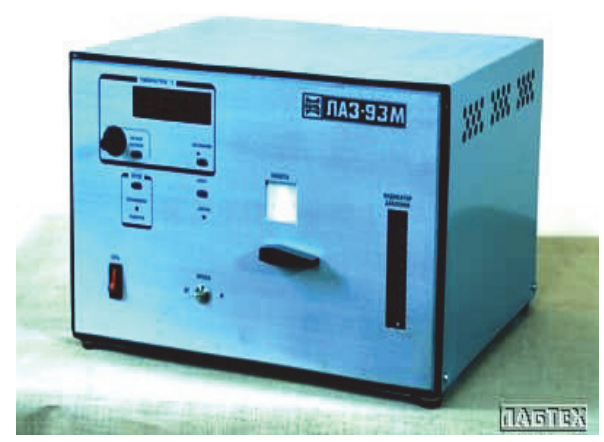
до $+10{ }^{\circ} \mathrm{C}$

Сходимость $-2{ }^{\circ} \mathrm{C}$; воспроизводимость $-6{ }^{\circ} \mathrm{C}$

Температурный датчик - платиновый термометр Детектирование потери подвижности - автоматическое. Система охлаждения - вода с температурой не более $+25{ }^{\circ} \mathrm{C}$ и расходом $0,04 \mathrm{~m}^{3} / \mathrm{ч}$

Температура окружающего воздуха - от $+10{ }^{\circ} \mathrm{C}$ до $+35{ }^{\circ} \mathrm{C}$

Параметры электропитания - 220 В, 50 Гц

Потребляемая мощность - 110 Вт

Габаритные размеры $-410 \times 380 \times 270$ мм Macca - 16 кг

Рисунок 21 - Аппарат лабораторный для определения температуры застывания нефтепродуктов ЛАЗ-93М

Аппарат для определения температуры застывания нефтепродуктов АТЗ является аналогом аппарата ЛАЗ-93М, имеет аналогичные технические характеристики.

Аппарат лабораторный для определения низкотемпературных характеристик дизельных топлив ЛАЗ-93М1 (рисунок 22) предназначен для автоматического определения температур застывания и помутнения всех видов дизельных топлив, включая арктические, в соответствии с ГОСТ 20287, ГОСТ 5066, ASTM D 97 и ASTM D 2500. 


\section{Технические характеристики:}

Диапазон определения температуры застывания - от -40 до $+10{ }^{\circ} \mathrm{C}$

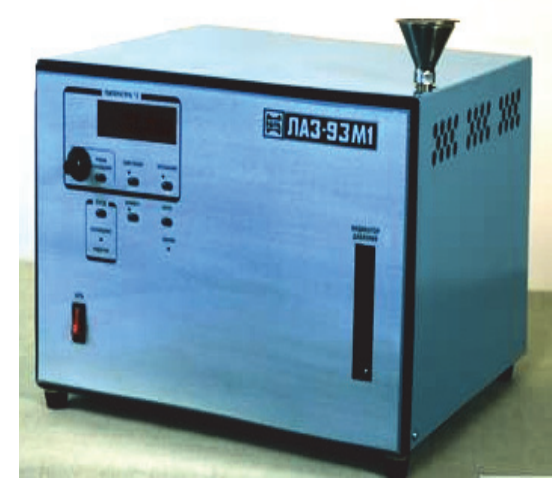

Сходимость $-2{ }^{\circ} \mathrm{C}$

Воспроизводимость $-6{ }^{\circ} \mathrm{C}$

Температурный датчик - платиновый термометр

Детектирование потери подвижности - автоматическое

Система охлаждения - вода с температурой не более $+25^{\circ} \mathrm{C}$ и расходом $0,04 \mathrm{~m}^{3} / \mathrm{u}$

Температура окружающего воздуха -

от +10 до $+35^{\circ} \mathrm{C}$

Параметры электропитания -220 В, 50 Гц

Потребляемая мощность -110 Вт

Габаритные размеры $-410 \times 380 \times 270$ мм

Масса -16 кг

Рисунок 22 - Аппарат лабораторный для определения температуры застывания нефтепродуктов ЛАЗ-93М1

Аппарат для определения температуры помутнения и начала кристаллизации светлых нефтепродуктов Кристалл-10Э (рисунок 23) предназначен для определения температур помутнения, застывания и начала кристаллизации светлых нефтепродуктов как в ручном режиме, так и в автоматическом режиме. Аппарат обеспечивает программное понижение температуры продукта, запоминание, возможность просмотра до 300 результатов испытаний.

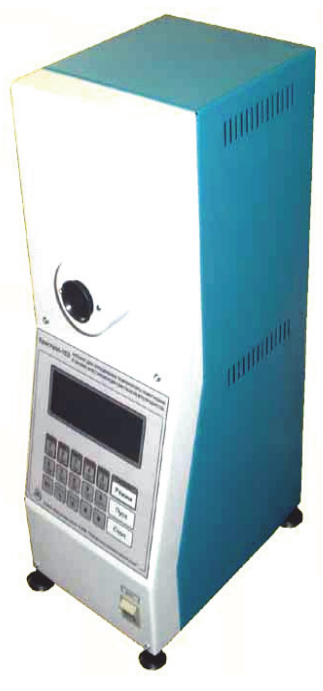

\section{Технические характеристики:}

Диапазон определения температур застывания и помутнения - от -65 до $+10{ }^{\circ} \mathrm{C}$

Объем ячейки для испытуемой проб $-8 \mathrm{~cm}^{3}$

Время охлаждения пробы до температуры $-65^{\circ} \mathrm{C}-$ не более 30 мин.

Погрешность определения температуры - не более $0,5^{\circ} \mathrm{C}$

Система охлаждения - вода с температурой не более $+20{ }^{\circ} \mathrm{C}$ и расходом от 4 до 10 л/мин.

Питание -220 В, 50Гц

Потребляемая мощность -300 Вт

Габаритные размеры $-200 \times 311 \times 540$ мм

Масса аппарата -10 кг

Рисунок 23 - Аппарат для определения температуры помутнения и начала кристаллизации светлых нефтепродуктов Кристалл-10Э 
Определение температуры застывания. Прибор для определения температуры застывания показан на рисунке 24.

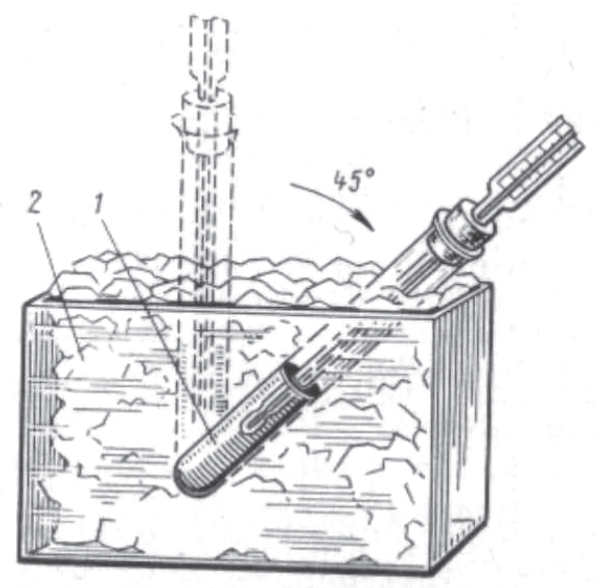

Рисунок 24 - Схема прибора для определения температуры застывания дизельного топлива: 1 - топливо; 2 - охлаждающая смесь

\section{6. Подготовка объекта}

Испытуемое топливо заливают в пробирку и помещают в стеклянную пробирку-муфту. Сверху пробирку-муфту закрывают пробкой. Прибор помещают в сосуд с охлаждающей смесью. При проведении опыта дизельное топливо перемешивают мешалкой, температуру измеряют термометром.

Применяют следующие охлаждающие смеси.

Для получения температур от 0 до $-20{ }^{\circ} \mathrm{C}$ в сосуд засыпают попеременно слой поваренной соли и слой снега или измельченного до 3 см льда. На одну часть соли берут две части снега или льда.

Для получения температур ниже $-20{ }^{\circ} \mathrm{C}$ в сосуд со слоем изоляции или термос наливают этиловый спирт на 2/3 его высоты. Затем вносят в спирт мелкими порциями деревянной или фарфоровой ложкой твердый диоксид углерода, наблюдая за тем, чтобы спирт не разбрызгивался. При необходимости после газовыделения в сосуд доливают спирт.

Перед определением испытуемое дизельное топливо обезвоживают, для чего взбалтывают его в течение $10 \ldots 15$ мин со свежепрокаленным и измельченным сульфатом натрия или с зернистым хлористым кальцием. Затем 
топливо отстаивают и фильтруют. Обезвоженное дизельное топливо наливают в пробирку, закрывают пробкой, в которую вставлен термометр. Шарик термометра должен находиться несколько выше дна пробирки. Пробирку вставляют в пробирку-муфту, в которую предварительно заливают 1 мл серной кислоты для поглощения влаги из воздуха и предупреждения появления на стенках пробирки-муфты капелек воды при охлаждении.

\subsection{1. Методика определения}

Собранный прибор опускают в охлаждающую смесь и устанавливают в строго вертикальном положении. Затем, начиная с температуры, которая на $9{ }^{\circ} \mathrm{C}$ выше предполагаемой температуры застывания дизельного топлива, через каждые $3{ }^{\circ} \mathrm{C}$ вынимают пробирку из пробирки-муфты и наблюдают за подвижностью дизельного топлива при наклоне. Извлекать пробирку из муфты и устанавливать ее обратно надо не более чем за 3 с. Когда при наклоне пробирки дизельное топливо остается неподвижным, пробирку устанавливают в горизонтальное положение и наблюдают за поверхностью топлива. Если в течение 5 с будет обнаружено смещение поверхности топлива, снова устанавливают пробирку в пробирку-муфту и проверяют текучесть топлива после охлаждения еще на $3{ }^{\circ} \mathrm{C}$.

\subsection{2. Обработка результатов измерений}

За температуру застывания испытуемого дизельного топлива принимают температуру, при которой топливо в горизонтально расположенной пробирке остается неподвижным в течение 5 с.

Определение температуры помутнения. Температура помутнения определяется по методу Б ГОСТ 5066-91 «Топлива моторные. Методы определения температуры помутнения, начала кристаллизации и кристаллизации». Сущность метода заключается в охлаждении пробы топлива и определении температуры помутнения. 
Определение проводят на приборе ЛТ3, который состоит из охлаждающей бани с мешалкой и прибора с зеркальным отражением света.

Охлаждающая баня представляет собой стеклянный цилиндрический сосуд Дьюара для охлаждающей смеси высотой не менее 200 мм, диаметром не менее 120 мм, установленный в металлическом корпусе. На крышке сосуда установлен электродвигатель привода мешалки и имеются отверстия для пробирки с двойными стенками, термометра и подачи твердой углекислоты.

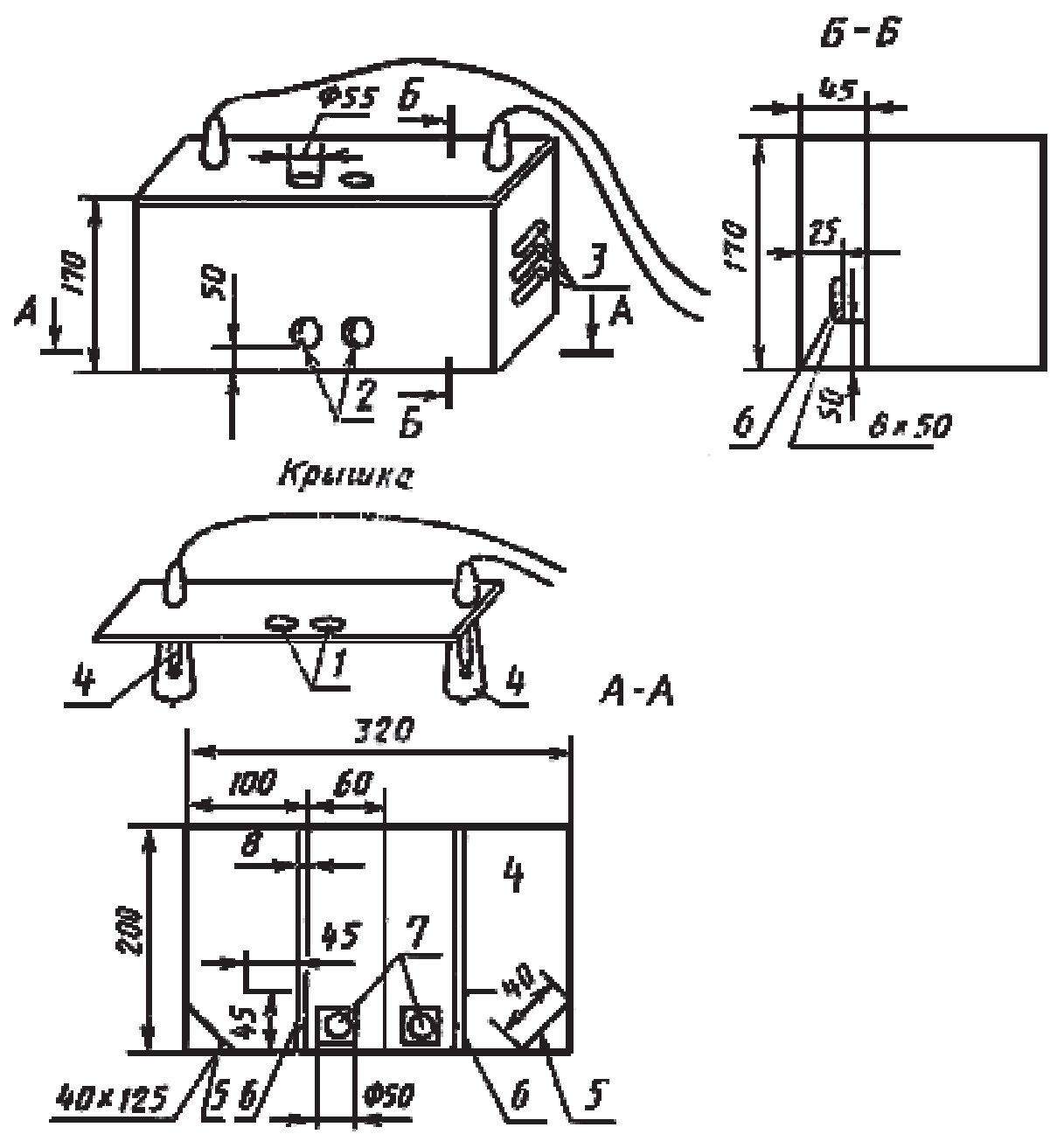

Рисунок 25 - Чертеж прибора с зеркальным отражением света: 1 - отверстия для пробирок; 2 - отверстия для наблюдения; 3 - вентиляционные щели; 4 - электролампы; 5 - зеркала; 6 - щели для прохождения света; 7 - подставки с выемкой для установки пробирок

Прибор с зеркальным отражением света (рисунок 25) предназначен для лучшего наблюдения эффекта помутнения и появления кристаллов в топливе. 
Прибор представляет собой металлический или деревянный с огнестойким покрытием прямоугольный ящик, разделенный глухой перегородкой пополам на два отделения одинакового устройства. Каждое отделение, в свою очередь, разделяется на два отсека по всей высоте перегородкой с отверстием - щелью для прохождения отраженного света и выступом, расположенным перпендикулярно к ней. Ящик снабжен крышкой с двумя вмонтированными электролампами мощностью $100 \ldots 150$ Вт, которые при закрывании крышки располагают в крайних отсеках, и с двумя отверстиями для опускания пробирок с испытуемым топливом в средние отсеки ящика. Передняя стенка ящика имеет два отверстия для наблюдения за испытуемым топливом.

\subsection{3. Подготовка объекта}

Испытуемое топливо помещается в стеклянную пробирку с двойными стенками внутренним диаметром 25...33 мм, наружным диаметром $35 \ldots 43$ мм. На внутренней стенке пробирки должна быть кольцевая метка на высоте 40 мм от дна. Боковые отростки пробирки могут быть запаяны или открыты. В последнем случае для предупреждения появления росы на стенках пробирки на дно наружной пробирки наливают $0,5 \ldots 1,0 \mathrm{~cm}^{3}$ серной кислоты.

В ходе определения топливо обязательно должно перемешиваться либо мешалкой, входящей в комплект прибора ЛТЗ, либо ручной мешалкой. Мешалки ручные или механические должны быть изготовлены из нержавеющей стали, алюминия или стекла. Каждая мешалка должна иметь выступ, не позволяющий нижней части мешалки подниматься выше уровня топлива.

\subsection{4. Методика определения}

Это испытание проводят в стеклянной пробирке с двойными стенками, внутренний диаметр которой 25...33 мм, наружный - 35...43 мм. На внутренней стенке на высоте 40 мм от дна сделана метка. 


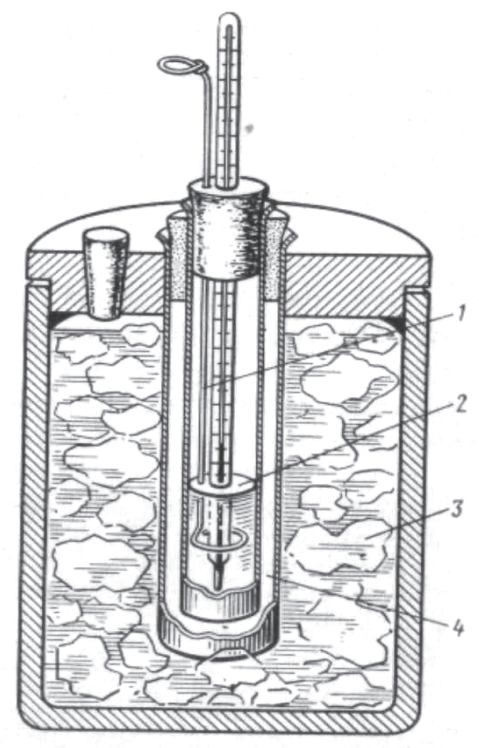

a

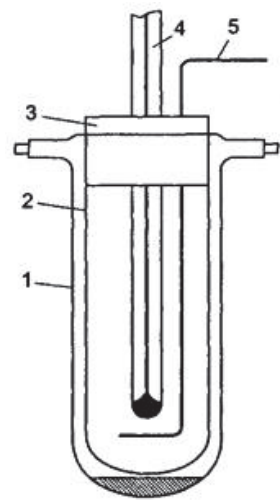

6

Рисунок 26 - Схема прибора для определения температуры помутнения дизельного топлива: а) 1 - мешалка; 2 - испытуемое топливо;

3 - охлаждающая смесь; 4 - воздух; б) 1 - пробирка наружная; 2 - пробирка внутренняя; 3 - пробка; 4 - термометр; 5 - мешалка

Если боковые отростки пробирки не запаяны, то в ее наружную часть для предупреждения появления росы на стенках наливают $0,5 \ldots 1 \mathrm{~cm}^{3}$ серной кислоты. Пробирку закрывают корковой пробкой, в которой укреплен термометр 3 и через которую проходит мешалка 1. Мешалки могут быть ручными или механическими, из стекла или металла. Пробирка с испытуемым дизельным топливом охлаждается в цилиндрическом сосуде со смесью из спирта и твердого диоксида углерода. Сосуд снабжен тепловой изоляцией, в его крышке находятся отверстия для пробирки, термометра и подачи твердого диоксида.

\subsection{5. Обработка результатов измерений}

За результат испытания принимают среднее арифметическое значение двух параллельных определений. 


\section{Контрольные вопросы и задания}

1. Какие эксплуатационные требования предъявляют к дизельным топливам?

2. От каких свойств топлива зависит хорошее смесеобразование?

3. Расскажите о влиянии испаряемости дизельного топлива на работу двигателя.

4. Что называют вязкостью дизельного топлива, и какое влияние она оказывает на работу двигателя?

5. Дайте определение температуры помутнения и застывания топлива.

6. В чем заключается физическая сущность помутнения и застывания топлива?

7. Какова эксплуатационная оценка дизельного топлива по температуре помутнения и застывания?

8. При какой температуре наружного воздуха может применяться данный образец топлива?

9. Перечислите марки дизельного топлива. 


\section{Лабораторная работа № 5 \\ ОПРЕДЕЛЕНИЕ ЦЕТАНОВОГО ЧИСЛА ДИЗЕЛЬНОГО ТОПЛИВА}

1.1. Цель работы: закрепить знания по теории образования горючей смеси и сгоранию топлива в дизельном двигателе, приобрести навыки по измерению и расчету цетанового числа дизельного топлива.

\section{2. Задачи работы:}

ознакомиться с методикой определения цетанового числа, с измерительным оборудованием и приборами;

провести подготовку дизельного топлива и оборудования к лабораторным испытаниям;

выполнить измерение цетанового числа дизельного топлива;

сравнить экспериментальные данные цетанового числа дизельного топлива с нормативными показателями, оценить представленные образцы дизельного топлива.

1.3. Оборудование и приборы: одноцилиндровая дизельная моторная установка ИТ9-3М.

1.4. Объект испытания: дизельное топливо, первичное и вторичное эталонное топливо.

\section{5. Порядок выполнения работы}

Цетановое число дизельного топлива определяют по методу ГОСТ 3122 и EN ISO 5165.

\section{Общие сведения}

Процессы смесеобразования и сгорания топлива в дизелях, особенно высокооборотных, происходят за очень короткое время, которое соответствует 
$15 \ldots 20^{\circ}$ поворота коленчатого вала. Это время примерно в 10 раз меньше, чем в карбюраторных двигателях.

Горючая смесь высокооборотных дизелей образуется непосредственно в цилиндре.

Качество смесеобразования и сгорания топлива зависит от давления и температуры сжатого воздуха, концентрации паров топлива в воздухе, тонкости распыла, испаряемости и химического состава топлива. Химический состав топлива является решающим фактором, определяющим температуру самовоспламенения, период задержки воспламенения и скорость распространения пламени в горючей смеси.

Период задержки воспламенения в дизеле предшествует процессу самовоспламенения. Этот период продолжается от начала подачи топлива в камеру сгорания до момента его воспламенения.

В период задержки воспламенения происходит целый ряд физикохимических процессов: распыливание топлива, перемешивание его с воздухом, нагревание до температуры сжатого воздуха и испарение. Одновременно с этим протекают сложные химические реакции многостадийного окисления углеводородов. В горючей смеси образуются неустойчивые кислородсодержащие соединения: перекиси, гидроперекиси, альдегиды и т. п., которые затем распадаются. Этот распад сопровождается выделением части $(10 \ldots 15 \%)$ энергии, содержащейся в топливе, и слабым холодным голубым свечением. В результате предпламенных реакций выделяется теплота, повышается температура горючей смеси, увеличивается скорость химических реакций, холоднопламенный процесс переходит в горячий, происходит самовоспламенение и горение топлива.

Дизельное топливо состоит в основном из парафиновых, нафтеновых и ароматических углеводородов. Наиболее склонны к окислению и самовоспламенению парафиновые углеводороды, более устойчивы нафтены и наиболее стойкие - ароматические углеводороды. 
Если период задержки воспламенения слишком велик, то смесь воспламеняется с опозданием, при этом в цилиндре дизеля накапливается и воспламеняется большая порция топлива. Это вызывает резкое нарастание давления, возникают стуки, наблюдается так называемая жесткая работа. В этом случае увеличиваются износ деталей, прорыв газов в картер двигателя, расход топлива.

Если при повороте коленчатого вала на $1^{\circ}$ давление в цилиндре возрастает на $0,25 \ldots 0,5 \mathrm{MПа,} \mathrm{то} \mathrm{работа} \mathrm{мягкая,} \mathrm{на} 0,6 \ldots 0,9 \mathrm{MПа} \mathrm{-} \mathrm{жесткая,} \mathrm{а}$ более чем на 1 МПа - очень жесткая, вызывающая быстрый износ двигателя. Оценкой самовоспламеняемости служит цетановое число, зависящее от химического состава топлива.

Цетановое число дизельного топлива равно содержанию (\% по объему) цетана в смеси с альфаметилнафталином, эквивалентной по воспламеняемости испытуемому топливу.

Цетановое число - основной показатель, характеризующий горючесть топлива, определяющий эффективность сгорания, высокие мощностные и экономические показатели работы двигателя (запуск двигателя, жесткость рабочего процесса, расход топлива и дымность отработавших газов). Чем выше цетановое число, тем ниже скорость нарастания давления, менее жестко работает двигатель. Однако при повышении цетанового числа топлива сверх оптимального, обеспечивающего работу двигателя с допустимой жесткостью, ухудшается его экономичность и повышается дымность отработавших газов. Чем выше цетановое число, тем быстрее произойдут процессы предварительного окисления топлива в камере сгорания, тем скорее воспламенится смесь и запустится двигатель. Применение топлива с цетановым числом менее 40 приводит к жесткой работе двигателя, а более 50 - к увеличению расхода топлива из-за уменьшения полноты сгорания. Летом можно применять топливо с цетановым числом равным 40, а зимой, для обеспечения холодного пуска двигателя - с цетановым числом не менее 45. 
Характерна взаимосвязь низкотемпературных свойств топлива и его цетанового числа.

\section{Проведение испытаний}

Цетановое число дизельного топлива определяют по методу ГОСТ 3122 и EN ISO 5165. Сущность метода заключается в сравнении самовоспламеняемости испытуемого топлива в двигателе при различных степенях сжатия с самовоспламеняемостью эталонных топлив с известными цетановыми числами в стандартных условиях испытания на одноцилиндровой дизельной моторной установке ИТ9-3М или ИДТ-69 методом совпадения вспышек на одноцилиндровых моторных установках типа ИТ9-3, ИТ9-3М и ИТД-69.

Моторная установка ИТ9-3 показана на рисунке 27.

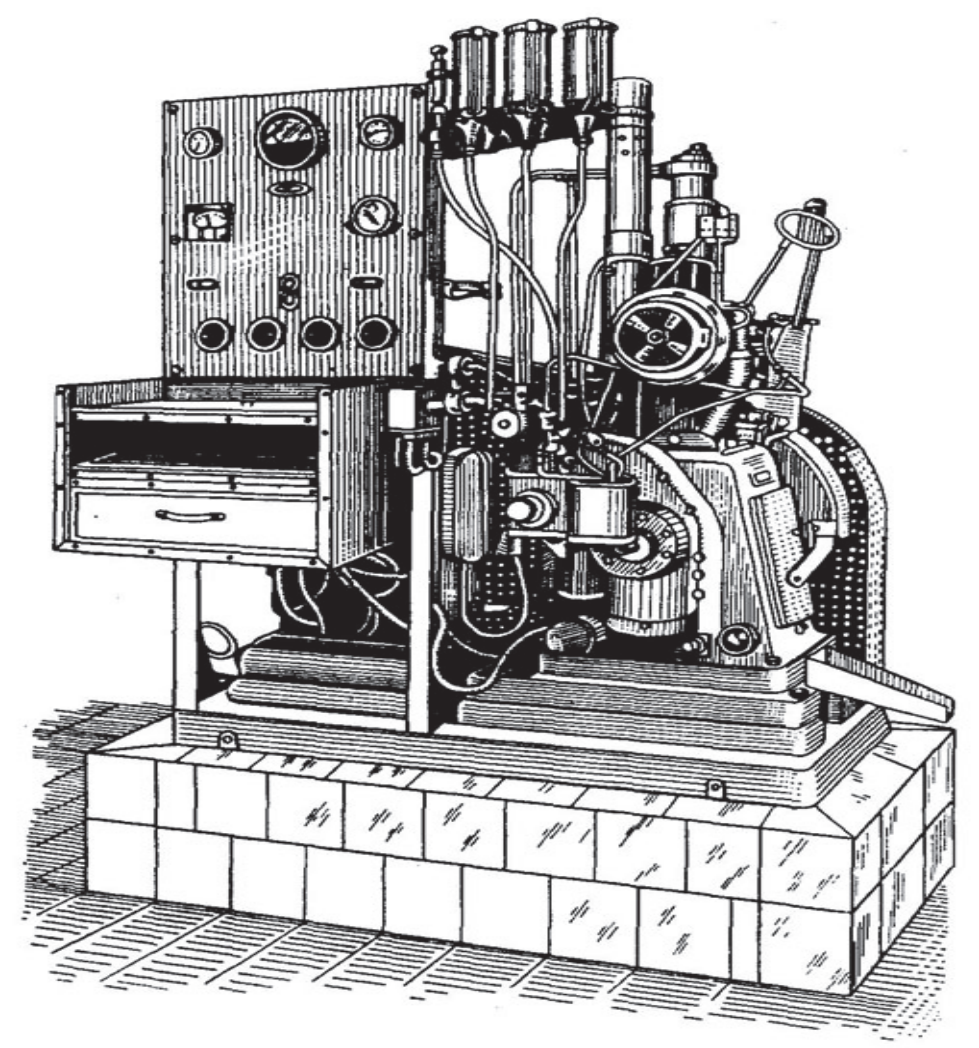

Рисунок 27 - Моторная установка ИТ9-3 для определения цетанового числа дизельного топлива 


\section{6. Подготовка объекта}

В таблице 7 даны условия, которые следует соблюдать при определении цетановых чисел на моторной установке.

Таблица 7 - Режим работы двигателя при определении цетанового числа

\begin{tabular}{|l|c|}
\hline \multicolumn{1}{|c|}{ Наименование показателя } & \multicolumn{1}{|c|}{ Норма } \\
\hline Частота вращения коленчатого вала, мин & \\
Степень сжатия & $900 \pm 10$ \\
Температура, С: & \\
$\quad$ охлаждающей жидкости в зарубашечном пространстве & Переменная от 7 до 23 \\
цилиндра & $100 \pm 2$ \\
$\quad$ воды, охлаждающей форсунку & $38 \pm 3$ \\
$\quad$ воздуха при впуске в двигатель & $65 \pm 1$ \\
$\quad$ масла в картере & $50 \ldots 65$ \\
Давление впрыскивания топлива, МПа & $104 \pm 0,4$ \\
Угол опережения впрыскивание топлива, град до в. м. т. & 13 \\
Количество впрыскиваемого топлива, мл/мин & $13 \pm 0,5$ \\
\hline
\end{tabular}

При определении цетанового числа применяют первичное и вторичное эталонное топливо.

Первичное эталонное топливо - это смесь цетана и альфаметилнафталина. Воспламеняемость цетана принята за 100 ед., а альфаметилнафталина - за 0. Цетан при сгорании в дизеле дает небольшой период задержки воспламенения и обеспечивает мягкую работу двигателя. Альфаметилнафталин очень трудно окисляется и воспламеняется, дает большой период задержки воспламенения и очень жесткую работу двигателя.

Вторичное эталонное топливо - это смесь газойля прямой перегонки из парафинистых малосернистых нефтей и зеленого масла, очищенного серной кислотой.

\subsection{1. Методика определения}

Испытание заключается в сравнении самовоспламеняемости испытуемого дизельного топлива и эталонного. Самовоспламеняемость испытуемого дизельного топлива определяют следующим образом. Двигатель пускают после предварительного подогрева картерного масла до $55 . . .60{ }^{\circ} \mathrm{C}$. Прогревают и устанавливают рабочий режим двигателя на товарном дизельном топливе, 
затем в топливный бак (рисунок 27) заливают испытуемое дизельное топливо и переключают на него моторную установку.

Во время работы двигателя на испытуемом топливе изменением положения рейки топливного насоса высокого давления устанавливают расход топлива $13 \pm 0,5$ мл/мин.

Регулируя зазор между контактами индикатора впрыскивания и микрометрического винта топливного насоса, добиваются, чтобы угол опережения впрыскивания топлива составлял $13^{\circ}$ до в. м. т.

Устанавливают критическую степень сжатия.

Критическая степень сжатия - это наименьшая степень сжатия, при которой двигатель работает без пропусков самовоспламенения.

Затем окончательно настраивают индикаторы впрыскивания и воспламенения, снабженные неоновыми лампочками. Сначала добиваются, чтобы лампочки индикатора на ободе маховика давали сплошные полосы света. Затем регулируют индикаторы до появления срезанного конца светящейся полосы неоновой лампочки.

Устанавливают степень сжатия совпадения вспышек неоновых ламп, при этом срезанные концы светящихся полос индикаторов впрыскивания и воспламенения должны находиться на одном уровне. Такое положение двух светящихся полос со срезанными концами на ободе маховика свидетельствует о совпадении вспышек индикаторов впрыскивания и воспламенения. В этом случае разница между моментом впрыскивания и воспламенения будет составлять $13^{\circ}$ поворота коленчатого вала.

Сравнение испытуемого дизельного топлива с эталонными смесями состоит в подборе двух смесей из цетана и альфаметилнафталина. Одна смесь должна давать совпадение вспышек неоновых ламп при большей степени сжатия, другая - при меньшей, чем степень сжатия совпадения вспышек, найденная для испытуемого дизельного топлива. Эти смеси должны различаться не более чем на четыре цетановые единицы. Определяют степень 
сжатия совпадения вспышек для испытуемого топлива и эталонных смесей попеременно не менее 3 раз.

\subsection{2. Обработка результатов измерений}

Содержание цетана (\% по объему) в первичной эталонной смеси цетана и альфаметилнафталина, эквивалентной по самовоспламеняемости испытуемому дизельному топливу, находят по формуле

$$
x=A_{1}+\left(A_{2}+A_{1}\right) \times \frac{a_{1}-a}{a_{1}-a_{2}},
$$

где $A_{1}$ - содержание цетана (\% по объему) в первичной эталонной смеси, дающей совпадение вспышек при большей степени сжатия, чем испытуемое дизельное топливо (смесь с меньшим цетановым числом); $A_{2}$ - то же, для смеси, дающей совпадение вспышек при меньшей степени сжатия, чем испытуемое дизельное топливо (смесь с большим цетановым числом); $a$ - среднее арифметическое показаний степени сжатия при совпадении вспышек для испытуемого дизельного топлива; $a_{1}$ - то же для смеси цетана и альфаметилнафталина, соответствующей $A_{1} ; \mathrm{a}_{2}$ - то же для смеси цетана и альфаметилнафталина, соответствующей $A_{2}$.

Испытуемое дизельное топливо сравнивают с вторичными эталонными смесями по той же методике и в той же последовательности, что и со смесями из цетана и альфаметилнафталина.

Результаты определения цетанового числа округляют до целых единиц. Расхождение результатов на одной установке не должно отличаться от их среднего арифметического более, чем на 1,5 цетановых единиц, на разных установках не более чем на \pm 2 цетановых единицы.

Цетановое число влияет на индикаторные характеристики дизеля: период задержки воспламенения, скорость нарастания давления и максимальное давление, удельный расход топлива.

При повышении цетанового числа топлива скорость нарастания давления снижается и уменьшаются жесткость работы двигателя, расход топлива и дымность отработавших газов. 


\section{Контрольные вопросы и задания}

1.Что такое цетановое число и какие свойства топлива оно характеризует?

2. В чем сущность жесткой работы дизельного двигателя?

3. Какие свойства топлива влияют на процессы распыла, смесеобразования и сгорания?

4. Что влияет на процессы нагарообразования в дизеле?

5. Какие соединения топлива вызывают коррозию деталей резервуаров, топливоподающей аппаратуры и двигателей?

6. Почему недопустимы механические примеси в топливе?

7. Какой вред оказывает вода, находящаяся в дизельном топливе летом, зимой?

8. Как действуют депрессорные присадки? 


\section{Лабораторная работа № 6 \\ ОПРЕДЕЛЕНИЕ ТЕМПЕРАТУРЫ ВСПЫШКИ}

1.1. Цель работы: закрепить знания по качественным показателям нефтепродуктов, их пожароопасности, приобрести навыки по измерению и расчету температуры вспышки нефтепродукта, оценить пожарную опасность производства, помещений и установок.

\section{2. Задачи работы:}

ознакомиться с методикой определения температуры вспышки нефтепродукта, с измерительным оборудованием и приборами;

провести подготовку образца нефтепродукта, оборудования к лабораторным испытаниям;

провести измерения температуры вспышки нефтепродукта;

вычислить температуру вспышки нефтепродукта с учетом поправок.

1.3. Оборудование и приборы: аппарат ТВЗ для определения температуры вспышки в закрытом тигле, полуавтоматический прибор ATB-1 и автоматический прибор АТВ-20.

1.4. Объект испытания: топливо дизельное.

\section{5. Порядок выполнения работы}

Определение температуры вспышки нефтепродукта следует проводить в соответствии с ГОСТ 6356-75 «Нефтепродукты. Метод определения температуры вспышки в закрытом тигле».

\section{Общие сведения}

Определение температуры вспышки используют для оценки качества нефтепродуктов и для классификации производства, помещений и установок по степени пожарной опасности. 
Температура вспышки нефтепродукта - минимальная температура, при которой происходит кратковременное воспламенение паров продукта от пламени в условиях испытания.

Температура вспышки характеризует пожароопасность нефтепродукта и зависит от его фракционного состава.

Температура вспышки в закрытом тигле должна быть для дизельного топлива летнего не ниже $40{ }^{\circ} \mathrm{C}$, зимнего - не ниже $35{ }^{\circ} \mathrm{C}$ и арктического - не ниже $30{ }^{\circ} \mathrm{C}$. Чем выше температура вспышки, тем меньше пожарная опасность топлива.

Температура вспышки нефтепродукта определяется по ГОСТ 6356-75 «Нефтепродукты. Метод определения температуры вспышки в закрытом тигле». Сущность метода заключается в определении самой низкой температуры топлива, при которой в условиях испытания над его поверхностью образуется смесь паров и газов с воздухом, способная вспыхивать в воздухе от источника зажигания, но скорость их образования еще недостаточна для последующего горения. Для этого испытуемый продукт нагревается в закрытом тигле с постоянной скоростью при непрерывном перемешивании и испытывается на вспышку через определенные интервалы температур.

\section{Оборудование для испытаний}

Для проведения испытаний используют аппарат ТВ3 (рисунок 28) для определения температуры вспышки в закрытом тигле, а также полуавтоматический прибор АТВ-1 и автоматический прибор АТВ-20. При разногласиях в оценке качества топлив применяют аппарат ТВ3. 


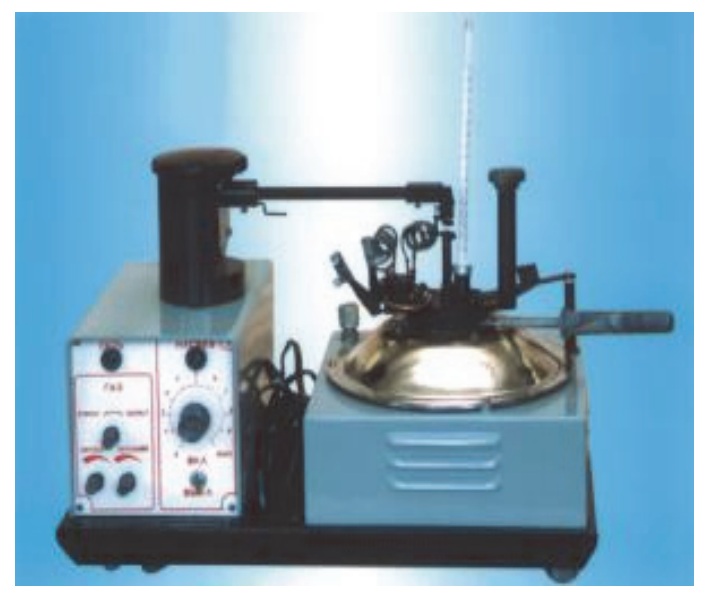

Рисунок 28 - Аппарат ТВ3 для определения температуры вспышки

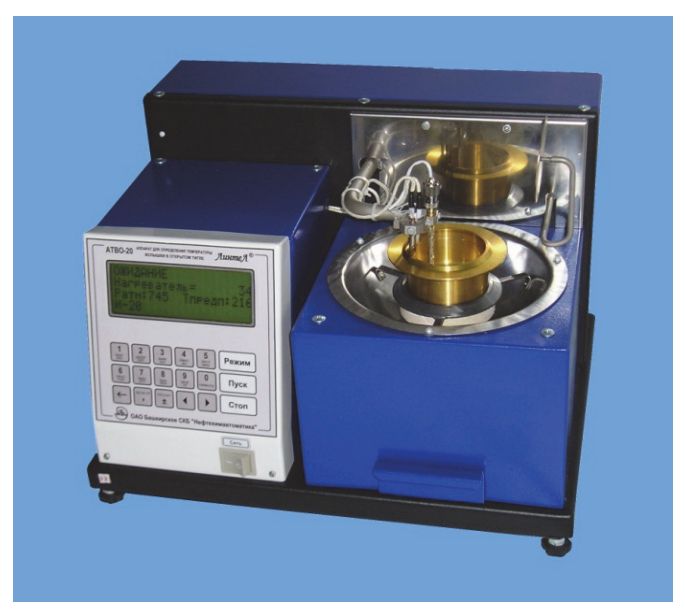

закрытом тигле

\section{Технические характеристики:}

Диапазон измерений - от 12 до $370{ }^{\circ} \mathrm{C}$

Точность определения температуры $\pm 0,1{ }^{\circ} \mathrm{C}$

Электрический поджиг, не требуется газ

Автоматическая фиксация момента воспламенения топлива

Корректировка температуры вспышки на барометрическое давление в диапазоне от 630 до 810 мМ. рт. ст.

Параметры электропитания: напряжение 220+22-33 B;

потребляемая мощность - не более 500 Вт; Габаритные размеры: $370 \times 400 \times 295$ мм Macca - 20 кг

Рисунок 29 - Автоматический аппарат для определения температуры вспышки

ATB-20

Аппарат для определения температуры вспышки нефтепродуктов в закрытом тигле показан на рисунке 30. 


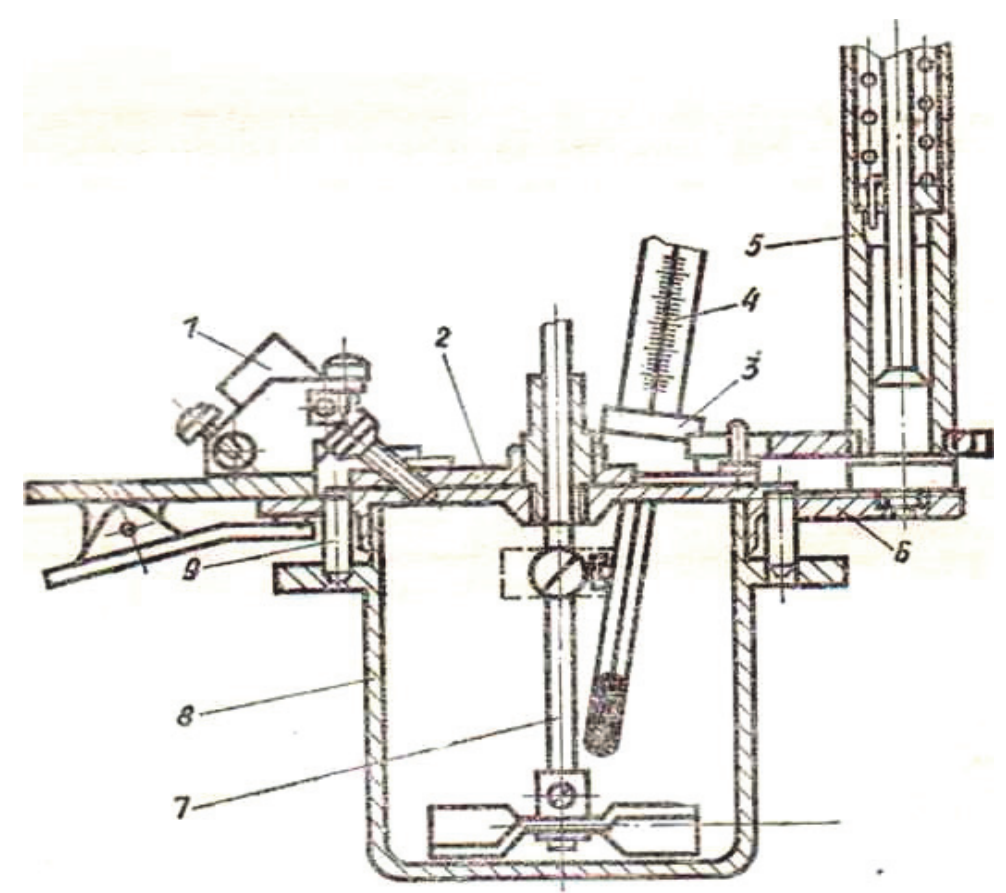

Рисунок 30 - Аппарат для определения температуры вспышки:

1 - зажигательное устройство; 2 - заслонка; 3 - переходная муфта термометра;

4 - термометр; 5 - пружинный механизм; 6 - крышка;

7 - мешалка; 8 - тигель; 9 - штифт крышки

Тигель 8 , крышка 6 , заслонки 2 и мешалки 7 аппарата изготовлены из латуни. На крышке расположено зажигательное устройство 1, пружинный механизм 5 перемещения заслонки, переходная муфта 3 термометра 4. В комплект аппарата входит воздушная баня. Тигель из гнезда бани вынимают с помощью ухвата. На внутренней стороне тигля выполнен круговой уступ, указывающий уровень испытуемого дизельного топлива.

Три отверстия трапецеидальной формы в крышке закрывают заслонкой 2. При вращении заслонки рукояткой отверстия крышки открываются, и зажигательная лампочка наклоняется к отверстию. В первоначальное положение заслонка и лампочка возвращаются под действием пружинного механизма 5 , расположенного в рукоятке перемещения заслонки.

Дизельное топливо перемешивается мешалкой с лопастями, приводимой во вращение электродвигателем; частота вращения мешалки - 90...120 мин ${ }^{-1}$. 
Аппарат снабжен регулятором скорости нагревания, который обеспечивает повышение температуры испытуемого нефтепродукта в тигле аппарата в режимах $5 \ldots 6{ }^{\circ} \mathrm{C}$ за $60 \mathrm{c}, 1{ }^{\circ} \mathrm{C}$ за $40 \ldots 60$ с и $1{ }^{\circ} \mathrm{C}$ за $30 \ldots 40 \mathrm{c}$.

К зажигательному и запальному устройствам подводится газ, давление которого должно быть не более 50 кПа $(0,5$ кгс/см²). Контрольный шарик аппарата диаметром 3...4 мм служит для регулирования формы пламени зажигательного устройства.

Электрическое питание аппарата - от сети переменного тока напряжением 220 В, частотой 50 Гц; мощность, потребляемая аппаратом, - не более $1000 \mathrm{~B}-\mathrm{A}$.

Для контроля вспышки дизельного топлива используют стеклянный термометр типа ТН-1 № 1 со шкалой от 0 до $+170{ }^{\circ} \mathrm{C}$.

\section{6. Подготовка объекта}

Перед испытанием образец дизельного топлива встряхивают 5 мин в бутылке, заполненной не более чем на $2 / 3$ ее вместимости. Затем топливо охлаждают до температуры, которая ниже предполагаемой температуры вспышки дизельного топлива (разница - до $17^{\circ} \mathrm{C}$ ).

Если в дизельном топливе содержится вода (не более $0,05 \%$ ), его обезвоживают свежепрокаленным хлористым натрием, хлористым кальцием или сернокислым натрием и фильтруют. На испытание берут верхний слой дизельного топлива.

Прибор устанавливают на столе и с трех сторон окружают экраном для защиты от потоков воздуха. Освещение несколько уменьшают, чтобы хорошо была видна вспышка.

Тигель и крышку прибора промывают растворителем, высушивают и охлаждают.

Тигель должен иметь температуру испытуемого топлива, a нагревательная ванна - температуру окружающей среды. 
Испытуемое дизельное топливо наливают в тигель до указателя уровня топлива, при этом смачивание стенок тигля выше этого уровня не допускается. Тигель закрывают крышкой, помещают в нагревательную ванну, устанавливают в переходную муфту термометр и зажигают лампочку зажигательного устройства. Пламя лампочки регулируют таким образом, чтобы форма ее соответствовала форме контрольного шарика диаметром 3 ...4 мм. Нагревательную ванну включают в электрическую сеть и нагревают испытуемое дизельное топливо в тигле. Топливо мешалкой должно перемешиваться при частоте вращения $90 \ldots 120$ мин $^{-1}$. По термометру следят за повышением температуры дизельного топлива в тигле, которая не должна повышаться более чем на $5 \ldots 6{ }^{\circ} \mathrm{C}$ в минуту. Барометром измеряют барометрическое давление.

\subsection{1. Методика определения}

Испытания на вспышку начинают в тот момент, когда температура топлива на $17{ }^{\circ} \mathrm{C}$ ниже предполагаемой температуры вспышки. В момент испытания мешалку выключают, приводят в действие расположенный на крышке механизм, который открывает заслонку. Опускают пламя, в паровое пространство тигля за 0,5 с, оставляют в нижнем положении 1 с и затем поднимают в верхнее положение. За температуру вспышки дизельного топлива принимают показания термометра при четком появлении первого синего пламени над поверхностью топлива внутри тигля. За вспышку нельзя принимать голубоватый ореол, который иногда окружает пламя перед тем, как произойдет фактическая вспышка. В случае появления неясной вспышки опыт повторяют при температуре на $1 . .2{ }^{\circ} \mathrm{C}$ выше. Если при этом вспышки нет, испытания повторяют.

Во время испытания газовая зажигательная лампочка должна гореть постоянно. 


\subsection{2. Обработка результатов измерений}

При давлении выше или ниже 101,325 кПа (760 мм рт. ст.) вводят поправку на стандартное давление. Ее определяют по формуле

$$
\begin{aligned}
& \Delta t=\frac{101,325-p}{3,3} \times 0,9 \\
& \text { или } \Delta t=0,0362 \times\left(760-p^{\prime}\right),
\end{aligned}
$$

где $p$ и $p^{\prime}$ - фактическое барометрическое давление, соответственно, кПа и мм рт. ст.

Можно также пользоваться поправками, приведенными в таблице 8.

Таблица 8 - Поправки на барометрические давления

\begin{tabular}{|c|c|c|}
\hline \multicolumn{2}{|c|}{ Барометрическое давление } & \multirow{2}{*}{ Поправка, ${ }^{\circ} \mathrm{C}$} \\
\hline кПа & мм рт. ст. & +4 \\
$84,8 \ldots 88,4$ & $636 \ldots 663$ & +3 \\
$88,5 \ldots 92,1$ & $664 \ldots 691$ & +2 \\
$92,2 \ldots 95,7$ & $692 \ldots 718$ & +1 \\
$95,8 \ldots 99,4$ & $719 \ldots 746$ & -1 \\
$103,2 \ldots 106,8$ & $774 \ldots 801$ & с \\
\cline { 1 - 2 } Температуру $\quad$ вспышки & с $\quad$ поправкой $\quad$ вычисляют & алгебраическим \\
\hline
\end{tabular}
сложением найденной температуры и поправки.

За результат испытаний принимают среднее арифметическое не менее двух последовательных определений, если расхождения между ними не превышают $2{ }^{\circ} \mathrm{C}$.

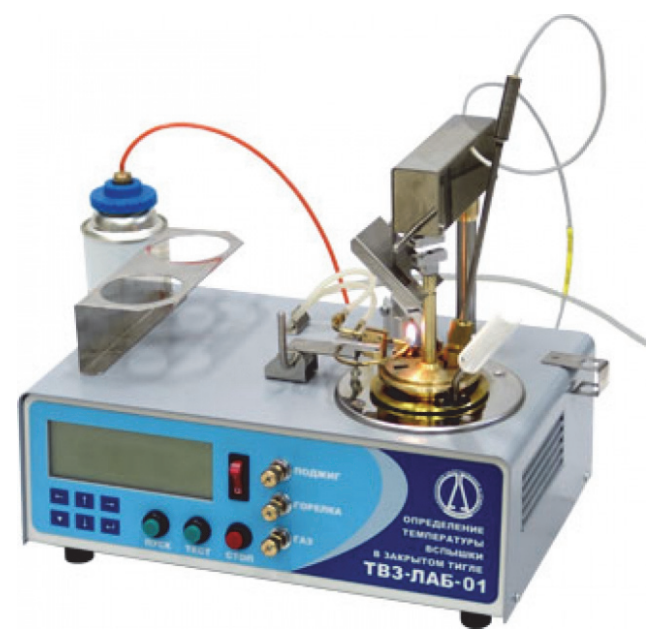

Рисунок 31 - Полуавтоматический аппарат для определения температуры вспышки в закрытом тигле по методу Пенски-Мартенса в соответствии с ГОСТ 6356, ISO 2719, ASTM D93 (метод А и B) 
С одной стороны экономичная альтернатива полностью автоматическим анализаторам, с другой стороны, простота и удобство проведения измерений по сравнению с ручными аппаратами.

\section{Как работает ТВЗ-ЛАБ-01}

Выбирается одна из заданных испытательных программ, соответствующая анализируемому продукту. Тигель с образцом помещается в камеру нагрева, привод мешалки устанавливается в рабочее положение, поджигается тестовое пламя газовой горелки. Нажатием клавиши ПУСК начинается нагрев образца. В ходе измерений аппарат автоматически нагревает пробу с требуемой скоростью и вводит в тигель испытательное пламя по выбранной программе. Каждый раз перед опусканием горелки в тигель, для привлечения внимания оператора прибор подает звуковой сигнал. Температура образца отображается на дисплее. Момент вспышки определяется визуально, при этом оператор нажимает кнопку СТОП. При нажатии кнопки СТОП на дисплее отображается температура вспышки.

Особенности конструкции: Большой символьный дисплей на 4 строки данных. Запатентованная конструкция магнитной муфты мешалки (между мотором и мешалкой отсутствует механическое зацепление) гарантирует высокую надежность перемешивающего механизма и обеспечивает исключительную простоту обращения с прибором. Газовая схема аппарата позволяет использовать портативные баллончики со сжиженным газом. Адаптер для подключения мини-баллонов входит в комплект поставки. Эффективный вентилятор по завершении эксперимента быстро охлаждает нагревательную камеру до заданной температуры.

Программные возможности: Память на 20 программ испытаний. Предустановленные программы для анализа различных продуктов (в т. ч. дизельные и печные топлива, авиационные топлива, мазуты, трансформаторное масло). Специальная программа для быстрого определения температуры вспышки неизвестного продукта. Возможность реализации различных 
полуавтоматических и ручного режимов. Специальные режимы для исследования высоковязких образцов.

\section{Технические характеристики ТВЗ-ЛАБ-01:}

Диапазон измерения температуры вспышки - от +15 до $+370^{\circ} \mathrm{C} *$

Частота вращения мешалки - 30...240 об/мин

Потребляемая мощность от сети переменного тока 220 В, не более - 600 ВТ

Габаритные размеры аппарата, не более $-350 \times 250 \times 280$ мм

Масса аппарата, не более - 6,5 кг

* При работе в области температур, ниже температуры окружающей среды, требуется предварительное охлаждение тигля с образцом, например, в морозильной камере.

Приложение

ГОСТ Р 52368-2005 (ЕН 590:2009). Топливо дизельное ЕВРО. Технические условия. [27.09.13]. Таблицы приведены в сокращенном виде.

\section{7. Технические требования}

1.7.1. Топливо должно соответствовать требованиям настоящего стандарта и изготовляться по технологии, утвержденной в установленном порядке.

1.7.2. По физико-химическим и эксплуатационным показателям топливо должно соответствовать требованиям, указанным в таблице 9.

\subsection{3. Климатические условия и методы испытаний}

Топливо для умеренных климатических условий должно соответствовать требованиям, указанным в таблице 10 .

Топливо для холодного и арктического климата должно соответствовать требованиям, указанным в таблице 11.

Топливо не должно содержать металлосодержащие присадки.

Допускается применение красителей, кроме зеленого и голубого цвета, и маркеров. 
Таблица 9 - Требования к топливу

\begin{tabular}{|c|c|c|}
\hline Наименование показателя & Значение & Метод испытания \\
\hline Цетановое число, не менее & 51,0 & $\begin{array}{l}\text { По ГОСТ } 3122, \text { ГОСТ } \mathrm{P} \\
52709, \text { ГОСТ Р } 15195\end{array}$ \\
\hline Цетановый индекс, не менее & 46,0 & \\
\hline Плотность при $15^{\circ} \mathrm{C}$, кг/куб.м & $820 \ldots 845$ & $\begin{array}{l}\text { По ГОСТ Р 51069, ГОСТ } \\
\text { Р ИСО 3675-2007 }\end{array}$ \\
\hline $\begin{array}{l}\text { Полициклические ароматические углеводороды } \\
\text { 3), \% (по массе), не более }\end{array}$ & 8,0 & \\
\hline $\begin{array}{l}\text { Содержание серы, мг/кг, не более, для топлива: } \\
\text { вид I } \\
\text { вид II } \\
\text { вид III }\end{array}$ & $\begin{array}{l}350,0 \\
50,0 \\
10,0\end{array}$ & $\begin{array}{l}\text { По ГОСТ Р } 51947 \\
\text { По [ГОСТ Р } 52660, \text { ГОСТ } \\
\text { Р ЕН ИСО } 20846 \\
\text { По ГОСТ Р } 52660, \text { ГОСТ } \\
\text { Р ЕН ИСО } 20846\end{array}$ \\
\hline Температура вспышки в закрытом тигле, ${ }^{\circ} \mathrm{C}$, выше & 55 & $\begin{array}{l}\text { По ГОСТ 6356, ГОСТ Р } \\
\text { ЕН ИСО } 2719\end{array}$ \\
\hline $\begin{array}{l}\text { Коксуемость } 10 \% \text {-ного остатка разгонки, \% (по } \\
\text { массе), не более }\end{array}$ & 0,30 & По или ГОСТ 19932 \\
\hline Зольность, \% (по массе), не более & 0,01 & По ГОСТ 1461 \\
\hline Содержание воды, мг/кг, не более & 200 & \\
\hline Общее загрязнение, мг/кг, не более & 24 & \\
\hline $\begin{array}{l}\text { Коррозия медной пластинки (3 ч при } 50 \text { C) } 6) \text {, } \\
\text { единицы по шкале }\end{array}$ & Класс 1 & \\
\hline $\begin{array}{l}\text { Окислительная стабильность: общее количество } \\
\text { осадка, г/ } \text { м }^{3} \text {, не более }\end{array}$ & 25 & $\begin{array}{l}\text { По ГОСТ } \\
12205\end{array}$ \\
\hline $\begin{array}{l}\text { Смазывающая способность: скорректированный } \\
\text { диаметр пятна износа при } 60^{\circ} \mathrm{C} \text {, мкм, не более }\end{array}$ & 460 & По ГОСТ Р ИСО 12156-1 \\
\hline Кинематическая вязкость при $40^{\circ} \mathrm{C}, \mathrm{mм}^{2} / \mathrm{c}$ & $2,00 \ldots 4,50$ & По ГОСТ 33 \\
\hline $\begin{array}{l}\text { Фракционный состав: } \\
\text { при температуре } 250{ }^{\circ} \mathrm{C}, \% \text { (по объему), менее } \\
\text { при температуре } 350{ }^{\circ} \mathrm{C}, \% \text { (по объему), не менее } \\
95 \% \text { (по объему) перегоняется при температуре, } \\
{ }^{\circ} \mathrm{C}, \text { не выше }\end{array}$ & $\begin{array}{l}65 \\
85 \\
360 \\
\end{array}$ & $\begin{array}{l}\text { По ГОСТ } 2177 \text { (метод А), } \\
\text { ГОСТ Р ЕН ИСО } 3405\end{array}$ \\
\hline $\begin{array}{l}\text { Содержание метиловых эфиров жирных кислот, \% } \\
\text { (по объему), не более }\end{array}$ & 7,0 & \\
\hline
\end{tabular}

Таблица 10 - Требования к топливу для умеренного климата

\begin{tabular}{|l|l|l|l|l|l|l|l|}
\hline \multicolumn{2}{|c|}{ Наименование показателя } & \multicolumn{5}{|c|}{ Значение для сорта } & \multicolumn{2}{|c|}{ Метод } \\
\cline { 2 - 7 } & $\mathrm{A}$ & $\mathrm{B}$ & $\mathrm{C}$ & $\mathrm{D}$ & $\mathrm{E}$ & $\mathrm{F}$ & испытания \\
\hline $\begin{array}{l}\text { Предельная температура фильтруемости, }{ }^{\circ} \mathrm{C}, \\
\text { не выше }\end{array}$ & 5 & 0 & -5 & -10 & -15 & -20 & $\begin{array}{l}\text { По ГОСТ } \\
22254\end{array}$ \\
\hline
\end{tabular}




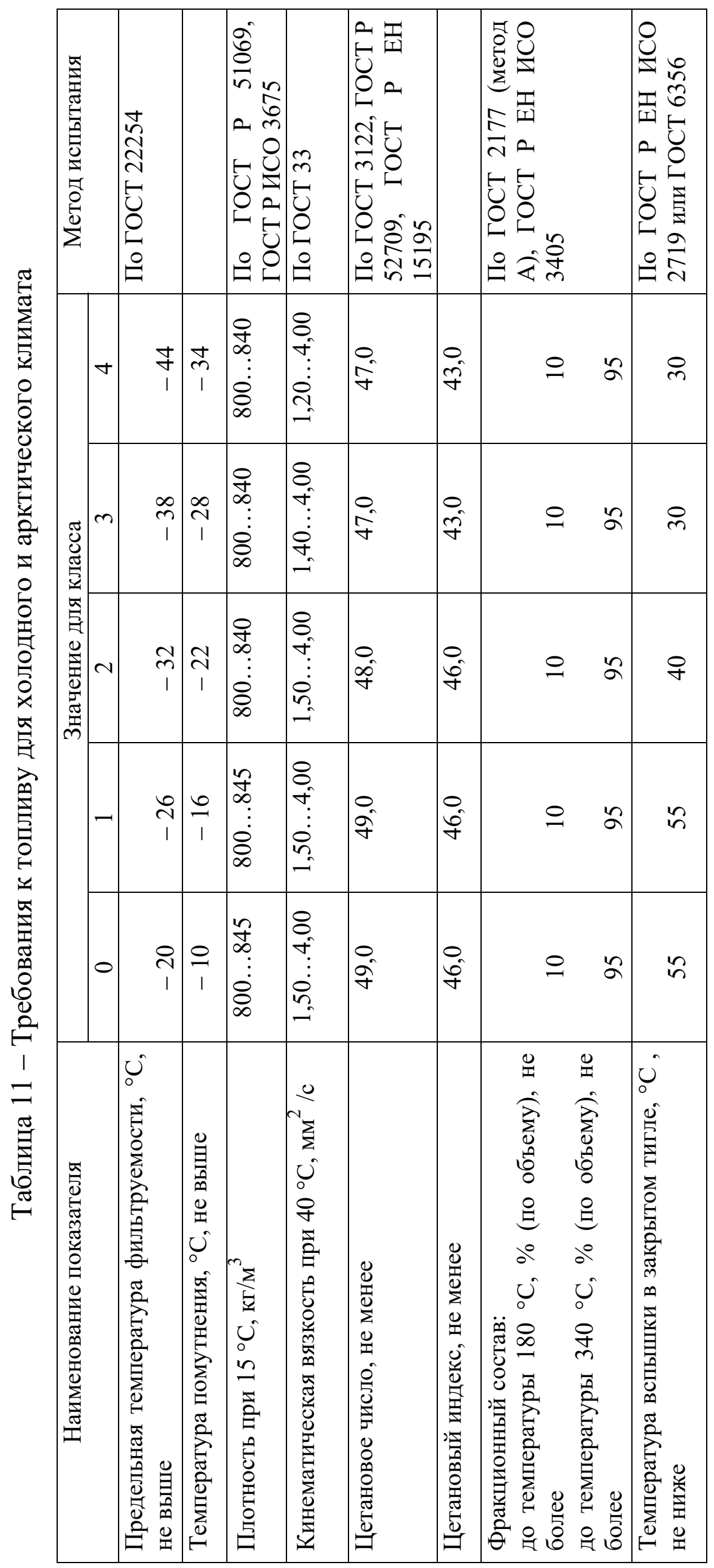




\subsection{4 Присадки}

Для улучшения эксплуатационных свойств топлив допускается использовать присадки, не причиняющие вреда здоровью граждан, окружающей среде, имуществу физических и юридических лиц, жизни и здоровью животных и растений.

\section{Контрольные вопросы и задания}

1. Что называют температурой вспышки, и какие свойства топлива она характеризует?

2. Как маркируют топлива для быстроходных дизелей?

3. Какими свойствами должно обладать экологически чистое дизельное топливо?

4. Какие приборы используют для определения температуры вспышки?

5. Какие требования к топливу для холодного и арктического климата? 


\section{Лабораторная работа № 7 \\ ОПРЕДЕЛЕНИЕ КИНЕМАТИЧЕСКОЙ ВЯЗКОСТИ \\ НЕФТЕПРОДУКТА}

1.1. Цель работы: закрепить знания по теории течения нефтепродуктов, приобрести навыки по измерению и расчету кинематической вязкости масла, оказывающее влияние на смазывающие свойства.

\section{2. Задачи работы:}

ознакомиться с методикой определения кинематической вязкости, с измерительным оборудованием и приборами;

провести подготовку оборудования и приборов к лабораторным испытаниям;

провести измерения кинематической вязкости нефтепродукта;

вычислить значение показателей кинематической вязкости.

1.3. Оборудование и приборы: капиллярные вискозиметры из стекла с малым коэффициентом температурного расширения, секундомер, термостат, термометр, электронагреватель, мешалка, электродвигатель.

1.4. Объект испытания: нефтепродукт (моторное масло).

\section{5. Порядок выполнения работы}

Кинематическая вязкость определяется по ГОСТ 33-2000 «Нефтепродукты. Прозрачные и непрозрачные жидкости. Определение кинематической вязкости и расчет динамической вязкости».

\section{Общие сведения}

Свойство жидкости оказывать сопротивление течению (перемещению одного слоя жидкости относительно другого) под действием внешней силы 
называется вязкостью (внутренним трением). Препятствие перемещению слоев жидкости создают силы молекулярного сцепления.

Вязкость - это внутреннее трение или сопротивление течению жидкости.

Вязкость определяют для жидких нефтепродуктов, напряжение сдвига которых пропорционально скорости деформации, то есть для ньютоновских жидкостей. Вязкость их не зависит от касательного напряжения и градиента скорости. Различают динамическую и кинематическую вязкости.

Динамическая вязкость, или коэффициент динамической вязкости, это отношение действующего касательного напряжения к градиенту скорости. Динамическая вязкость служит мерой сопротивления жидкости течению.

За единицу динамической вязкости в системе СИ принята вязкость такой жидкости, которая оказывает сопротивление в 1 Н взаимному перемещению двух

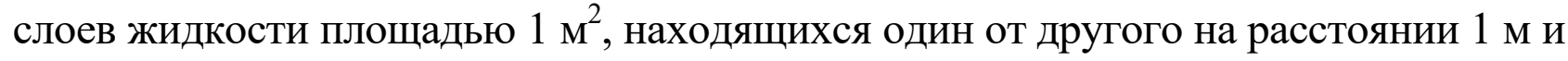
перемещающихся с относительной скоростью 1 м/с.

Схема взаимного перемещения слоев жидкости показана на рисунке 32.

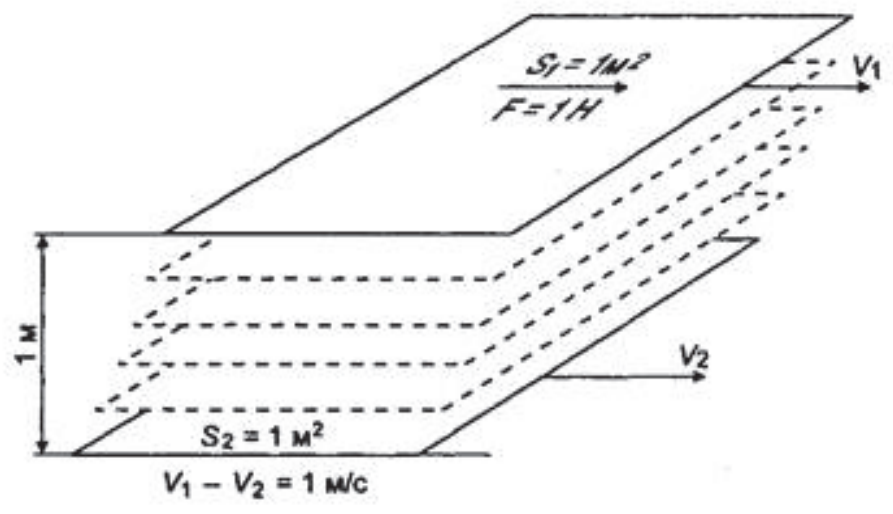

Рисунок 32 - Схема взаимного перемещения слоев жидкости

Единицей динамической вязкости в системе СИ является паскаль-секунда (Па-с). На практике применяют мПа.с $=10^{-3}$ Па·с, а также сантипуаз (сП = $\mathrm{M \Pi a} \mathrm{c})$.

Динамическую вязкость $\eta$ находят как произведение кинематической вязкости жидкости $\vartheta$ и ее плотности $\rho$ при той же температуре:

$$
\eta=\vartheta \times \rho
$$


Кинематическая вязкость - это отношение динамической вязкости $\eta$ жидкости к плотности $\rho$ при той же температуре:

$$
\vartheta=\eta / \rho \text {. }
$$

Кинематическая вязкость служит мерой сопротивления жидкости течению под влиянием гравитационных сил.

Метод определения кинематической вязкости заключается в измерении времени истечения определенного объема испытуемой жидкости под влиянием силы тяжести.

\section{Кинематическую вязкость находят как произведение измеренного} времени истечения и постоянной прибора для определения вязкости.

В системе СИ единицей кинематической вязкости является $\mathrm{m}^{2} / \mathrm{c}$. На практике применяется меньшая единица $-\mathrm{Mm}^{2} / \mathrm{c}=10^{-6} \mathrm{M}^{2} / \mathrm{c}$, а также сантистокс $\left(\mathrm{cCT}=\mathrm{MM}^{2} / \mathrm{c}\right)$.

Вязкость топлива в оптимальных пределах обеспечивает бесперебойную работу двигателя и минимальный износ смазываемых топливом деталей. Топливо с высокой вязкостью может нарушить заданный режим подачи и повысить потери на трение.

Кинематическая вязкость - сопротивление жидкости течению под действием гравитации (ГОСТ 33-2000).

Кинематическая вязкость характеризует прокачиваемость и смазывающие свойства горючего. Она зависит как от группового и углеводородного состава нефтепродукта, так и от внешних факторов температуры, давления (нагрузки), скорости сдвига. Высоковязкое топливо плохо прокачивается по топливной системе. Низкая вязкость горючего не обеспечивает оптимальный режим трения, что повышает износ деталей двигателя.

Кинематическая вязкость дизельных топлив находится в пределах $1,5 \ldots 6,0 \mathrm{mм}^{2} / \mathrm{c}$ (при $\left.20^{\circ} \mathrm{C}\right)$.

Кинематическая вязкость определяется по ГОСТ 33-2000 «Нефтепродукты. Прозрачные и непрозрачные жидкости. Определение 
кинематической вязкости и расчет динамической вязкости». Сущность метода заключается в измерении времени истечения, определенного объема нефтепродукта, под влиянием силы тяжести через калиброванный стеклянный вискозиметр, при фиксированной температуре (для топлив 20 и 40 ̊ $\mathrm{C}$ ).

\section{Аппаратура}

Для определения кинематической вязкости нефтепродуктов применяются капиллярные вискозиметры из стекла с малым коэффициентом температурного расширения (таблица 12).

Таблица 12 - Вискозиметры, применяемые для различных диапазонов вязкости

\begin{tabular}{|l|l|}
\hline \multicolumn{1}{|c|}{ Тип вискозиметра } & $\begin{array}{c}\text { Диапазон вязкости, } \\
\text { мм } / \mathrm{c}\end{array}$ \\
\hline Вискозиметры типа Оствальда для прозрачных жидкостей: & $0,5 \ldots 20000$ \\
Канон-Фенске Пинкевича (ВПЖТ-4) & $0,6 \ldots 10000$ \\
ВПЖТ-2 & $0,6 \ldots 17000$ \\
Вискозиметры с висячим уровнем для прозрачных жидкостей: & $0,6 \ldots 30000$ \\
ВПЖТ-1 (БС/ИП/СЛ) & $(3,5 \ldots 100000)$ \\
Уббелоде & $0,3 \ldots 100000$ \\
Вискозиметры с обратным протоком для прозрачных и непрозрачных & $0,6 \ldots 20000$ \\
жидкостей: & $(0,4 \ldots 20000)$ \\
ВНЖТ (Канон-Фенске-Опакв) & $0,6 \ldots 300000$ \\
БС/ИП/РФ & \\
\hline
\end{tabular}

Для вискозиметров типа Оствальда и с висячим уровнем время истечения должно быть не менее 200 с, а для вискозиметров с обратным протоком - более $200 \mathrm{c}$.

Во избежание необходимости введения поправок на кинематическую энергию вискозиметры рассчитаны на время истечения более 200 с, за исключением специальных указаний. Поэтому каждый диапазон кинематической вязкости требует использования вискозиметров определенного диаметра.

Отечественная промышленность выпускает вискозиметры типов ВПЖ-1, ВПЖ-2, ВПЖ-4, ВПЖТ-1, ВПЖТ-2, ВПЖТ-4, ВНЖ, ВНЖТ. Вискозиметры типа ВПЖ и ВНЖ выпускаются десяти типоразмеров, с диаметром капилляра от 0,34 до 6,85 мм. Вискозиметры типа ВПЖТ выпускаются семи типоразмеров, с диаметром капилляра от 0,37 до 1,47 мм. 
Вискозиметры типа ВНЖТ выпускаются пяти типоразмеров, с диаметром капилляра от 0,45 до 1,41 мм.

Определение кинематической вязкости проводят при строго заданной температуре. Для этого вискозиметр погружают в термостат с регулируемой температурой достаточной глубины, чтобы в момент измерения расстояния от образца в вискозиметре до верхнего уровня жидкости в бане и от образца до дна бани были не менее 20 мм. В интервале температур от 15 до $100{ }^{\circ} \mathrm{C}$ термостат должен обеспечивать точность поддержания температуры $\pm 0,02^{\circ} \mathrm{C}$ по всей высоте вискозиметров или в пространстве между вискозиметрами и местом расположения термометра. Для температур, находящихся вне указанного интервала, изменения температуры не должны превышать $\pm 0,05{ }^{\circ} \mathrm{C}$. Общий вид современных термостатов для определения кинематической вязкости представлен на рисунке 33.

Жидкостной термостат предназначен для точного поддержания температуры в диапазоне температур от +20 до $+100{ }^{\circ} \mathrm{C}$ имеет встроенный блок терморегулирования. При температурах ниже $45{ }^{\circ} \mathrm{C}$ требуется охлаждение термостата проточной водой с помощью встроенного теплообменника.

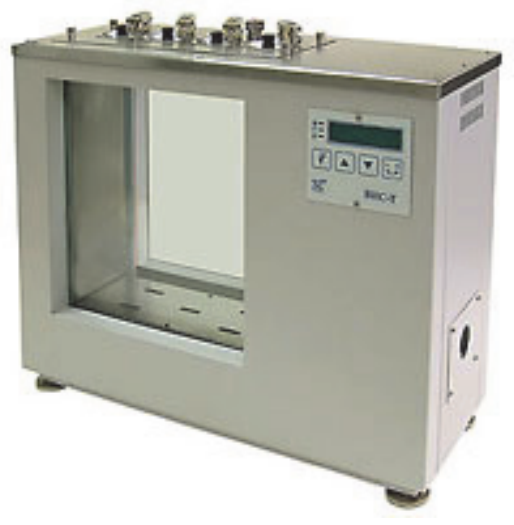

Технические характеристики:

Стабильность поддержания температуры $\pm 0,01{ }^{\circ} \mathrm{C}$ Градиенты температуры на 100 мм высоты $\pm 0,01{ }^{\circ} \mathrm{C}$ Потребляемая мощность от сети переменного тока 220B $-2,2$ кВт Габаритные размеры $-470 \times 250 \times 420$ мм Размеры внутренней ванны $-282 \times 110 \times 337$ мм Количество тестовых мест -4 в ряд Необходимый объем теплоносителя - 20 л Масса термостата без теплоносителя -23 кг

Рисунок 33 - Термостат для определения кинематической вязкости при положительных температурах VIS-T-05

Для наполнения термостата используют прозрачную жидкость, которая остается в жидком состоянии при температуре испытания. В зависимости от температуры испытания для заполнения термостата рекомендуется использовать следующие реактивы: 
от -60 до $15{ }^{\circ} \mathrm{C}$ - спирт этиловый технический или спирт этиловый ректификат, или изооктан технический по ГОСТ 4095;

от 15 до $60{ }^{\circ} \mathrm{C}$ - дистиллированную воду;

от 60 до $100{ }^{\circ} \mathrm{C}$ - глицерин по ГОСТ 6824, разбавленный водой 1:1, или светлое нефтяное масло;

свыше $90{ }^{\circ} \mathrm{C}-25$ \%-ный раствор азотнокислого аммония по ГОСТ 22867.

Для контроля над температурой жидкости в термостате используют калиброванные жидкостные стеклянные термометры с точностью после корректировки не менее $\pm 0,02{ }^{\circ} \mathrm{C}$ или выше или другие термометрические устройства равноценной или более высокой точности. При применении калиброванных жидкостных стеклянных термометров рекомендуется использовать два термометра. Если в одном и том же термостате используются два термометра, показания их при этом не должны отличаться более чем на 0,04 ㄷ․

Для измерения температур вне диапазона от 0 до $100{ }^{\circ} \mathrm{C}$ следует использовать калиброванные жидкостные стеклянные термометры с точностью после корректировки $\pm 0,05{ }^{\circ} \mathrm{C}$ и выше, а при применении двух термометров в одном и том же термостате их показания не должны отличаться более чем на $\pm 0,1{ }^{\circ} \mathrm{C}$.

ГОСТ 33-2000 требует использовать либо зарубежные термометры заданных характеристик, либо допускает использование термометров ТИН-10 по ГОСТ 400 или термометров ТР- I, TP-II по ГОСТ 13646. Однако термометры ТИН-10 имеют цену деления 0,05 ㄷ, в то время как ГОСТ 33-2000 требует контролировать температуру термостата с точностью $\pm 0,02{ }^{\circ} \mathrm{C}$. Поэтому для определения кинематической вязкости рекомендуется использовать специально выпускаемые отечественной промышленностью термометры для точных измерений типа ТР.

Время истечения жидкости через капилляр вискозиметра измеряется устройством, дающим возможность отсчета времени с точностью до 0,1 с и имеющим погрешность измерения $\pm 0,07 \%$, когда снимают показания в 
интервале от 200 до 900 сек. Допускается использование секундомеров с ценой деления 0,2 сек.

В качестве термостата или бани вискозиметра используют прозрачный стеклянный термостатирующий сосуд с водой (рисунок 34).

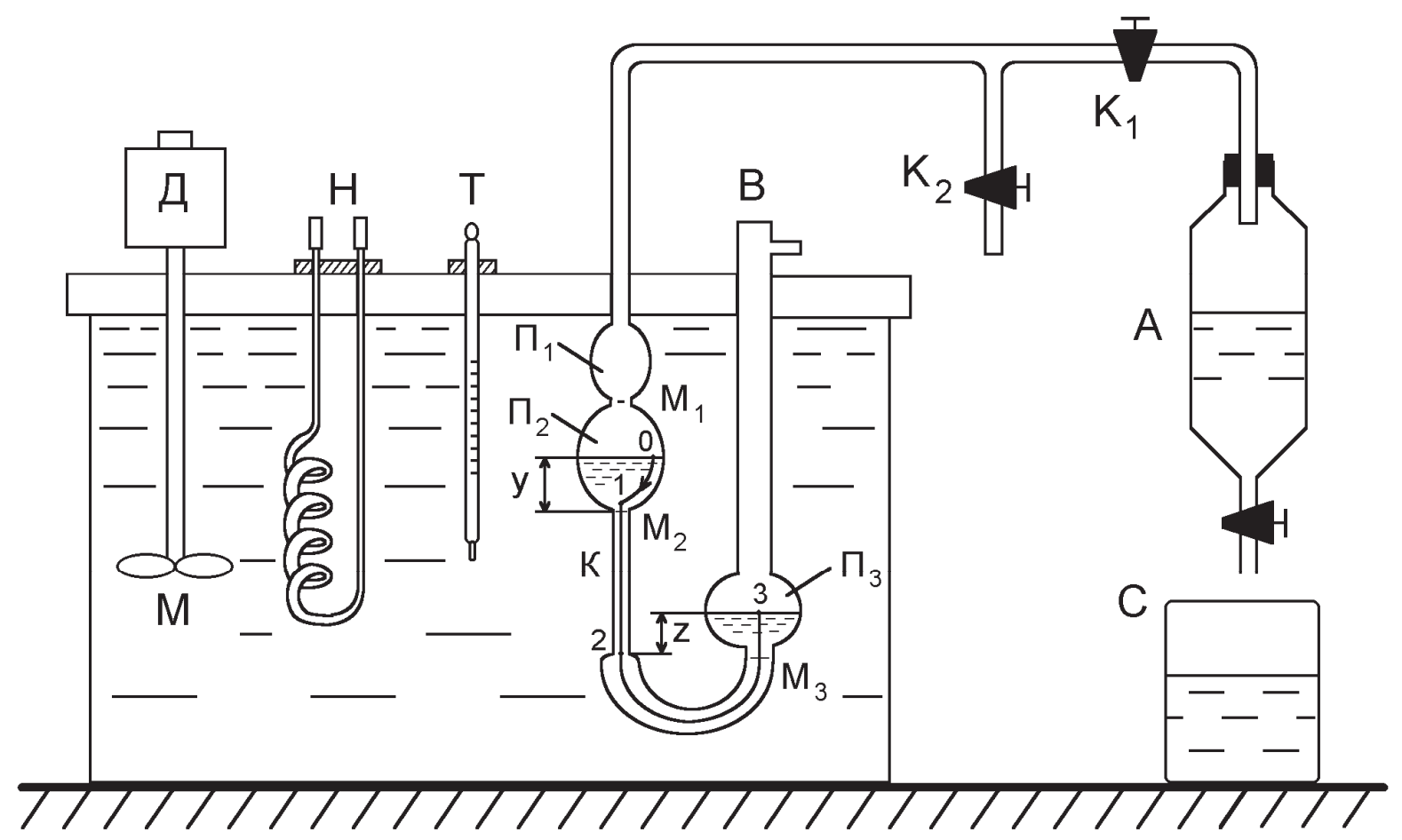

Рисунок 34 - Лабораторная установка для измерения коэффициента вязкости жидкостей при разных температурах: В - капиллярный вискозиметр; T - термометр; Н - электронагреватель; М - мешалка;

$$
\text { Д - электродвигатель }
$$

Используемый в работе капиллярный вискозиметр Оствальда В представляет собой U-образную стеклянную трубку, одно колено которой имеет две полости $\Pi_{1}, \Pi_{2}$ и капилляр К. На нижней и верхней сторонах полости $\Pi_{2}$ нанесены кольцевые метки $\mathrm{M}_{1}, \mathrm{M}_{2}$, ограничивающие некоторый объем $\mathrm{V}_{0}$, являющийся константой прибора. Другое колено вискозиметра представляет собой широкую трубку с полостью $\Pi_{3}$ и боковым отростком. В обычной практике, когда прибор держат в руках, этот отросток соединяется с резиновой грушей для закачивания исследуемой жидкости в узкое колено вискозиметра. Перед этим определенная порция ее вливается в широкую трубку 
вискозиметра. В данной работе вместо груши используется аспиратор А, соединенный с узким коленом вискозиметра через тройник. Засасывание жидкости в полость П $\Pi_{2}$ вискозиметра производится разрежением воздуха, возникающим в аспираторе при вытекании из него воды при открытом кранике $K_{1}$ и закрытом кранике $K_{2}$. После того как уровень воды в узком колене поднимется несколько выше метки $\mathrm{M}_{1}$, краник $\mathrm{K}_{1}$ перекрывают и открывают краник $\mathrm{K}_{2}$, соединяющий полость $\Pi_{1} \mathrm{c}$ атмосферой. Жидкость получает возможность свободно стекать через капилляр в нижнюю часть прибора и полость П $\Pi_{3}$. При этом измеряется время $\mathrm{t}$, за которое уровень жидкости в узком колене опускается от метки $\mathrm{M}_{1}$ до метки $\mathrm{M}_{2}$. Это время прохождения через капилляр определенного объема жидкости $\mathrm{V}_{0}$ связано с коэффициентом вязкости формулой.

В лаборатории используется следующая схема прибора рисунок 35.

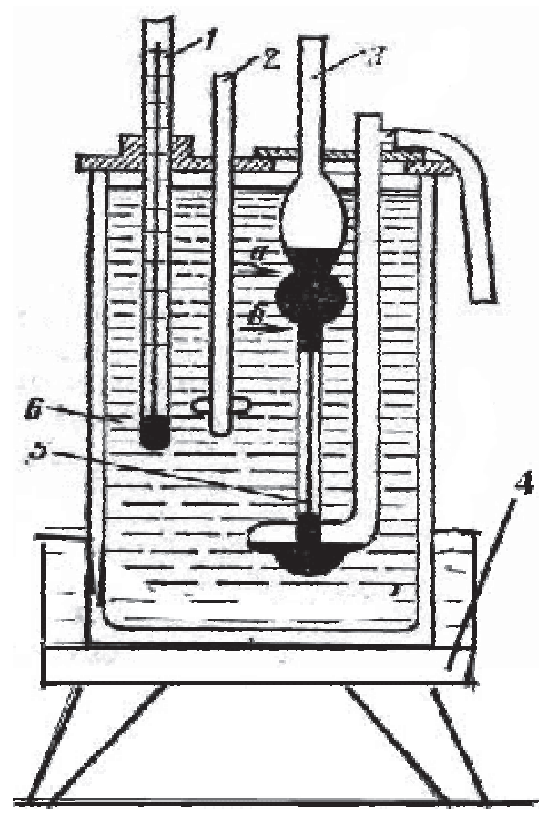

Рисунок 35 - Прибор для определения кинематической вязкости нефтепродукта: 1 - термометр; 2 - мешалка; 3 - вискозиметр;

4 - электроподогреватель; 5 - капилляр вискозиметра;

$$
6 \text { - термостат (баня) }
$$

Нефтепродукт, находящийся в вискозиметре, погружают не менее чем на 20 мм ниже уровня жидкости в бане и на 20 мм над дном сосуда. Баню 
вискозиметра снабжают устройством для регулирования температуры жидкости.

Для заполнения термостата используют следующие жидкости: технический этиловый спирт - для температуры от -60 до $+15{ }^{\circ} \mathrm{C}$; дистиллированную воду - для температуры от 15 до $60{ }^{\circ} \mathrm{C}$; глицерин или раствор глицерина с водой 1:1 или светлое нефтяное масло - для температуры свыше $60{ }^{\circ} \mathrm{C}$.

\section{Проведение испытаний}

Перед проведением испытания подбирают вискозиметр с пределами измерения, соответствующими ожидаемой вязкости испытуемого нефтепродукта. Вискозиметр должен быть сухим и чистым. Между определениями вискозиметр промывают растворителем и сушат воздухом. В качестве растворителей применяют бензин-растворитель для резиновой промышленности, нейтральный эфир, ацетон, толуол и т. п. Периодически вискозиметр промывают хромовой смесью, затем прополаскивают дистиллированной водой, ацетоном и сушат воздухом.

\section{6. Подготовка объекта}

Пробу нефтепродукта фильтруют через сито, стеклянный или бумажный фильтр. При необходимости нефтепродукт сушат безводным сульфонатом натрия или прокаленной крупнокристаллической поваренной солью и затем фильтруют через бумажный фильтр. Если вязкость нефтепродукта определяют при температуре ниже $95^{\circ} \mathrm{C}$, то его предварительно подогревают. Вискозиметр заполняют испытуемым нефтепродуктом и помещают в баню, где устанавливают нужную температуру.

\subsection{1. Методика определения}

При определении кинематической вязкости нефтепродуктов с помощью вискозиметров типа Оствальда и вискозиметров с висячим уровнем время 
истечения определяют не менее трех раз, а при использовании вискозиметров с обратным потоком - не менее двух.

\subsection{2. Обработка результатов измерений}

Кинематическую вязкость $\vartheta\left(\mathrm{mm}^{2} / \mathrm{c}\right)$ испытуемого нефтепродукта определяют по формуле

$$
\vartheta=\mathrm{C} \times \tau,
$$

где $\mathrm{C}$ - постоянная вискозиметра, $\mathrm{mm}^{2} / \mathrm{c}^{2}$ (дана в свидетельстве о проверке); $\tau$ - среднее арифметическое значение времени истечения нефтепродукта в вискозиметре, с.

Результаты расчета кинематической вязкости записывают до четырех значащих цифр.

Кинематическую вязкость $v$ вычисляют отдельно для каждого из двух вискозиметров.

За результат определения кинематической вязкости испытуемой пробы топлива принимают среднее арифметическое рассчитанных значений кинематической вязкости на каждом из вискозиметров, если расхождение между ними не превышает $0,35 \%$ от среднего значения.

Различные виды вискозиметров представлены на рисунке 36.

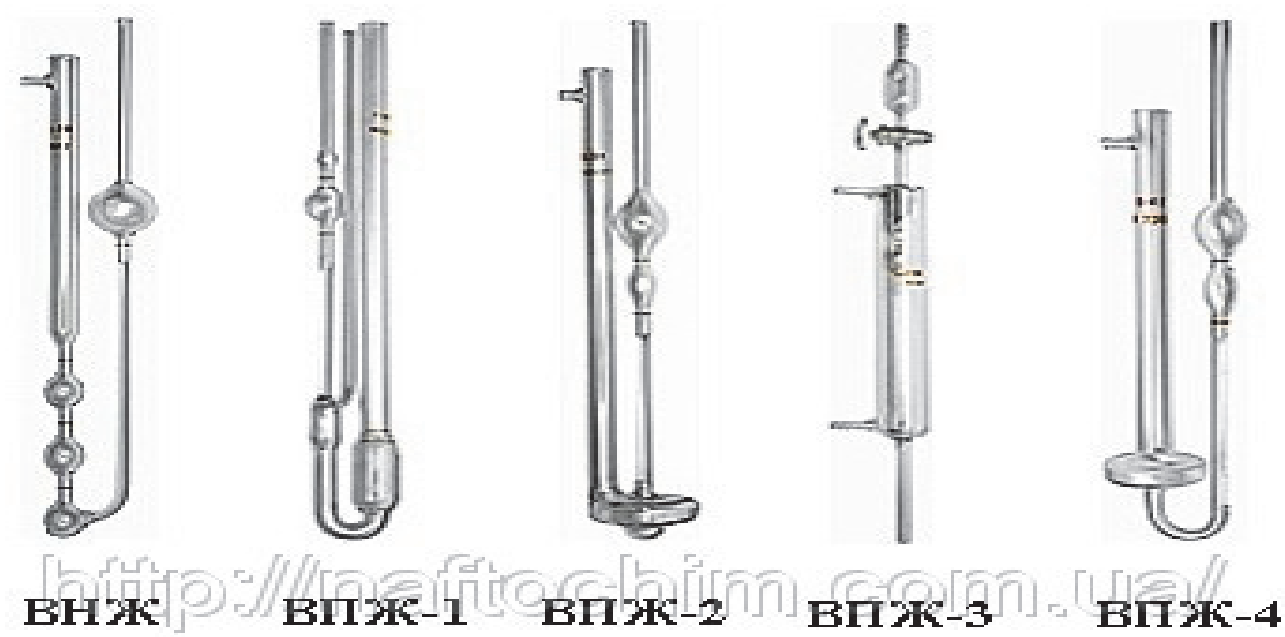

Рисунок 36 - Различные типы вискозиметров 


\section{Контрольные вопросы и задания}

1. Какие эксплуатационные требования предъявляют к смазочным материалам?

2. В чем разница между жидкостным и граничным режимами трения?

3. Какие свойства масел влияют на износ при жидкостном и граничном трении?

4. Как влияет вязкость масла на работу трущихся поверхностей?

5. Как можно понизить температуру застывания масел?

6. В чем сущность процесса окисления?

7. Как определяется кинематическая вязкость нефтепродукта?

8. Какие приборы используют для определения вязкости? 


\section{Лабораторная работа № 8 \\ ОПРЕДЕЛЕНИЕ ВЯЗКОСТНО-ТЕМПЕРАТУРНЫХ СВОЙСТВ \\ МОТОРНОГО МАСЛА}

1.1. Цель работы: закрепить знания по оценке вязкостно-температурных свойств моторного масла, приобрести навыки по измерению и расчету индекса вязкости, оказывающему влияние на эксплуатационные свойства масла.

\section{2. Задачи работы:}

ознакомить с методикой определения параметров, с измерительным оборудованием и приборами;

провести подготовку масла и оборудования к лабораторным испытаниям; провести измерения вязкостно-температурных свойств моторного масла; вычислить индекс вязкости образцов моторного масла.

1.3. Оборудование и приборы: капиллярные вискозиметры из стекла с малым коэффициентом температурного расширения, секундомер, термостат, термометр, электронагреватель, мешалка, электродвигатель.

1.4. Объект испытания: моторное масло.

\section{5. Порядок выполнения работы}

Кинематическая вязкость определяется по ГОСТ 33-2000 «Нефтепродукты. Прозрачные и непрозрачные жидкости. Определение кинематической вязкости и расчет динамической вязкости».

1.6. Подготовка объекта (смотрите работу № 7).

1.6.1. Методика определения (смотрите работу № 7).

Общие сведения 
Вязкость служит основным параметром моторных масел. По нему маркируют масла. От вязкости моторного масла при рабочих температурах в двигателе зависит качество смазывания трущихся деталей и их износ.

Кинематическая вязкость смазочных масел определяется, как правило, при температурах 50 или $100{ }^{\circ} \mathrm{C}$ (по ГОСТ 33-2000). Сущность метода, порядок определения показателя, применяемые приборы такие же, как при проведении анализа горючего.

При определении вязкости масел возможно как завышение, так и занижение результата.

Завышение результата чаще всего является следствием уменьшения проходного сечения капиллярной трубки вискозиметра. Проходное сечение капилляра могут уменьшать мелкодисперсные механические примеси, содержащиеся как в отработанных маслах, так и в отобранных из систем смазки агрегатов. Кроме того, такое же отрицательное влияние могут оказывать присадки, содержащиеся в товарных маслах. Поэтому после анализа таких масел необходимо проводить очистку вискозиметра от возможных отложений, чтобы они не накапливались и в дальнейшем не влияли на результат испытания.

Заниженные результаты возможны при анализе масел, содержащих противоизносные и вязкостные присадки. Такие масла обладают высокими адгезионными свойствами и за короткое время полностью не стекают со стенок расширенной части вискозиметров. Поэтому при анализе таких масел увеличение времени испытания дает более правильные результаты.

Вязкость моторного масла изменяется в зависимости от температуры: с повышением температуры вязкость понижается. Интенсивность изменения вязкости масла при изменении температуры у различных моторных масел неодинакова. Характер вязкостно-температурной кривой оценивается индексом вязкости (ИВ).

Индекс вязкости характеризует изменение вязкости масел в зависимости от температуры, т.е. пологость вязкостно-температурной кривой масла. 
Вязкость моторных масел с высоким индексом при изменении температуры изменяется незначительно, а вязкость масел с низким индексом значительно.

Индекс вязкости масел оценивают в условных единицах. Определяют его способом сравнения кривой вязкости испытуемого масла с аналогичными кривыми двух эталонных масел. Одно из них характеризуется очень пологой кривой, его индекс вязкости принят за 100 ед., другое - крутой кривой, индекс вязкости принят за 0 ед. Вязкость эталонных и испытуемого масел одинакова при температуре $100{ }^{\circ} \mathrm{C}$.

Моторные масла с более высоким индексом вязкости обладают лучшими технико-эксплуатационными свойствами. Для повышения индекса вязкости в моторные масла добавляют вязкостные присадки.

Загущенными называются масла, содержащие вязкостную присадку. Маловязкое минеральное масло характеризуется пологой кривой. В это масло добавляют вязкостные присадки (полиизобутилены и полиалкилметакрилаты). Получают загущенное моторное масло, вязкость которого при $100{ }^{\circ} \mathrm{C}$ увеличена за счет добавления вязкостной присадки, а вязкость при $0{ }^{\circ} \mathrm{C}$ примерно такая же, как и у маловязкого незагущенного минерального масла. Таким образом, получают загущенное масло с пологой вязкостно-температурной кривой и высоким индексом вязкости.

Загущенные масла обладают хорошими вязкостно-температурными свойствами и текучестью при низких температурах, способствуют легкому и быстрому пуску двигателя в холодное время года, образуют небольшое количество нагара и обеспечивают минимальные потери мощности на трение, что ведет к экономии топлива.

Для подсчета индекса вязкости определяют кинематическую вязкость испытуемого моторного масла при 40 и $100{ }^{\circ} \mathrm{C}$. Порядок определения изложен в работе № 7 . 


\subsection{2. Обработка результатов измерений}

Индекс вязкости ИВ вычисляют по формулам:

$$
\begin{aligned}
\text { ив } & =\frac{\vartheta-\vartheta_{1}}{\vartheta-\vartheta_{2}} \times 100 ; \\
\text { ив } & =\frac{\vartheta-\vartheta_{1}}{\vartheta_{3}} \times 100,
\end{aligned}
$$

где $\vartheta$ - кинематическая вязкость масла при $40{ }^{\circ} \mathrm{C}$ с индексом вязкости, равным 0 , обладающего при $100{ }^{\circ} \mathrm{C}$ такой же кинематической вязкостью, как испытуемое масло, $\mathrm{Mm}^{2} / \mathrm{c}(\mathrm{cC}) ; \vartheta_{1}-$ кинематическая вязкость испытуемого масла при $40^{\circ} \mathrm{C}, \mathrm{Mm}^{2} / \mathrm{c}$ $(\mathrm{cC}) ; \vartheta_{2}-$ кинематическая вязкость масла при $40{ }^{\circ} \mathrm{C}$ с индексом вязкости, равным 100 , обладающего при $100{ }^{\circ} \mathrm{C}$ такой же кинематической вязкостью, как испытуемое масло, $\mathrm{mм}^{2} / \mathrm{c}(\mathrm{cC})$

$$
\vartheta_{3}=\vartheta-\vartheta_{2}
$$

По этим формулам вычисляют ИВ, если кинематическая вязкость масла при $100{ }^{\circ} \mathrm{C}$ находится в пределах $2 \ldots 70 \mathrm{~mm}^{2} / \mathrm{c}(\mathrm{cC})$.

Значения $\vartheta$ и $\vartheta_{3}$ берут из таблицы 14. Если для найденного значения кинематической вязкости испытуемого моторного масла в этой таблице не указаны $\vartheta$ и $\vartheta_{3}$, но оно находится в диапазоне приведенных значений, то $\vartheta$ и $\vartheta_{3}$ рассчитывают методом линейной интерполяции.

Индекс вязкости моторного масла округляют до целого числа. Точность расчета при 95 \%-ной доверительной вероятности должна соответствовать данным таблицы 13.

Если для измеренного значения кинематической вязкости испытуемого масла в таблице 13 не указана точность, но эти значения находятся в диапазоне приведенных значений, их рассчитывают методом линейной интерполяции. 
Таблица 13 - К определению индекса вязкости

\begin{tabular}{|c|c|c|c|c|}
\hline \multirow{3}{*}{$\begin{array}{l}\text { Кинематическа } \\
\text { я вязкость при } \\
100^{\circ} \mathrm{C}, \quad \mathrm{MM}^{2} / \mathrm{c} \\
\text { (сСт) }\end{array}$} & \multicolumn{4}{|c|}{ Точность } \\
\hline & \multicolumn{2}{|r|}{ ИВ $=0$} & \multicolumn{2}{|r|}{ ИВ $=100$} \\
\hline & повторяемость & воспроизводимость & повторяемость & воспроизводимость \\
\hline 4 & 2,4 & 4,8 & 1,7 & 3,4 \\
\hline 6 & 2,1 & 4,2 & 1,3 & 2,6 \\
\hline 8 & 1,9 & 3,7 & 1,1 & 2,2 \\
\hline 15 & 1,5 & 3,0 & 0,7 & 1,4 \\
\hline 30 & 1,2 & 2,5 & 0,4 & 0,9 \\
\hline
\end{tabular}

\section{Пример расчета}

В результате проведенных испытаний было установлено, что вязкость испытуемого моторного масла при $40{ }^{\circ} \mathrm{C}$ равна $61,58 \mathrm{~mm}^{2} / \mathrm{c}(\mathrm{cC})$, а при $100{ }^{\circ} \mathrm{C}-$ $8 \mathrm{MM}^{2} / \mathrm{c}(\mathrm{cCT})$.

По таблице 14 находят $\vartheta=100, \vartheta_{3}=40,4 \mathrm{Mm}^{2} / \mathrm{c}(\mathrm{cC})$.

Полученные данные подставляют в уравнение :

ИВ $=[(100-61,58): 40,4] \times 100=95,1$.

Индекс вязкости округляют до целого числа: ИВ=95.

По таблице 13 находим повторяемость и воспроизводимость для кинематической вязкости $8 \mathrm{~mm}^{2} / \mathrm{c}(\mathrm{cC})$ :

ИВ $=0$, повторяемость $-1,9$, воспроизводимость $-3,7$.

ИВ $=100$, повторяемость $-1,1$, воспроизводимость $-2,2$.

По этим данным интерполяцией для ИВ $=95$ получают повторяемость 1,14 , воспроизводимость $-2,28$. 


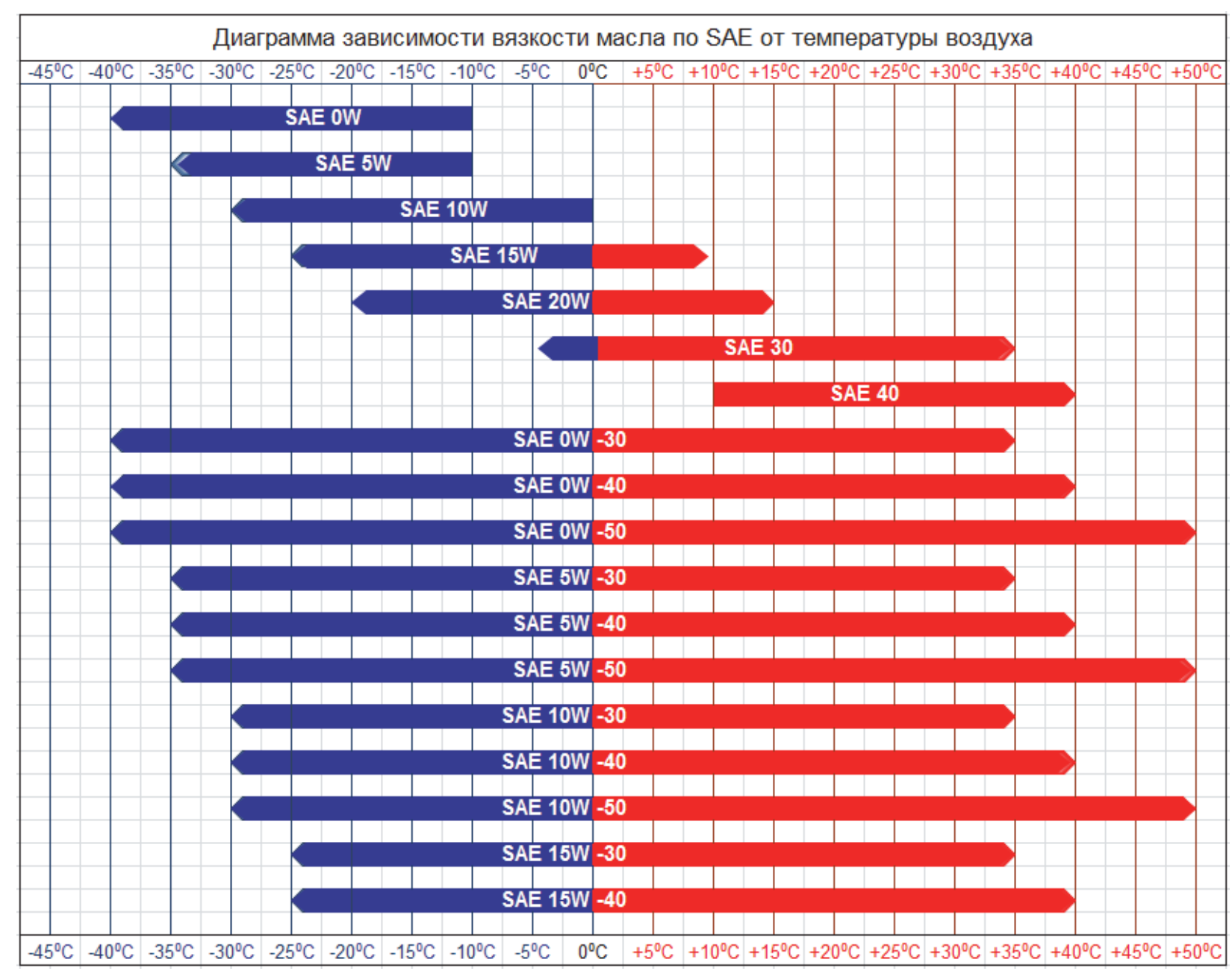

Рисунок 37 - Диаграмма зависимости вязкости масла по SAE от температуры воздуха

Таблица 14 - Значение кинематической вязкости масел при $100{ }^{\circ} \mathrm{C}, \mathrm{Mm}^{2} / \mathrm{c}(\mathrm{cC}$ )

\begin{tabular}{|c|c|c|c|c|c|c|c|}
\hline $\begin{array}{c}\text { Кинематическая } \\
\text { вязкость при } \\
100^{\circ} \mathrm{C}, \mathrm{Mm}^{2} / \mathrm{c} \\
(\mathrm{cC} \text { ) }\end{array}$ & $\vartheta$ & $\vartheta_{3}$ & $\vartheta_{2}$ & $\begin{array}{c}\text { Кинематическая } \\
\text { вязкость при } \\
100{ }^{\circ} \mathrm{C}, \mathrm{Mм}^{2} / \mathrm{c} \\
\text { (сСт) }\end{array}$ & $\theta$ & $\vartheta_{3}$ & $\vartheta_{2}$ \\
\hline 6,0 & 57,97 & 19,78 & 38,19 & 11,1 & 176,6 & 80,20 & 96,45 \\
\hline 6,1 & 59,74 & 20,57 & 39,17 & 11,2 & 179,4 & 81,65 & 97,71 \\
\hline 6,2 & 61,52 & 21,38 & 40,15 & 11,3 & 182,1 & 83,13 & 98,97 \\
\hline 6,3 & 63,32 & 22,19 & 41,13 & 11,4 & 184,9 & 84,63 & 100,2 \\
\hline 6,4 & 65,18 & 23,03 & 42,14 & 11,5 & 187,6 & 86,10 & 101,5 \\
\hline 6,5 & 67,12 & 23,94 & 43,18 & 11,6 & 190,4 & 87,61 & 102,8 \\
\hline 6,6 & 69,16 & 24,92 & 44,24 & 11,7 & 193,3 & 89,18 & 104,1 \\
\hline 6,7 & 71,29 & 25,96 & 45,33 & 11,8 & 196,2 & 90,75 & 105,4 \\
\hline 6,8 & 73,48 & 27,04 & 46,44 & 11,9 & 199,0 & 92,30 & 106,7 \\
\hline 6,9 & 75,72 & 28,21 & 47,51 & 12,0 & 201,9 & 93,87 & 108,0 \\
\hline 7,0 & 78,00 & 29,43 & 48,57 & 12,1 & 204,8 & 95,47 & 109,4 \\
\hline 7,1 & 80,25 & 30,63 & 49,61 & 12,2 & 207,8 & 97,07 & 110,7 \\
\hline
\end{tabular}




\begin{tabular}{|c|c|c|c|c|c|c|c|}
\hline 7,2 & 82,39 & 31,70 & 50,69 & 12,3 & 210,7 & 98,66 & 112,0 \\
\hline 7,3 & 84,53 & 32,74 & 51,78 & 12,4 & 213,6 & 100,3 & 113,3 \\
\hline 7,4 & 86,66 & 33,79 & 52,88 & 12,5 & 216,6 & 101,9 & 114,7 \\
\hline 7,5 & 88,85 & 34,87 & 53,98 & 12,6 & 219,6 & 103,6 & 116,0 \\
\hline 7,6 & 91,04 & 35,94 & 55,09 & 12,7 & 222,6 & 105,3 & 117,4 \\
\hline 7,7 & 93,20 & 37,01 & 56,20 & 12,8 & 225,7 & 107,0 & 118,7 \\
\hline 7,8 & 95,43 & 38,12 & 57,31 & 12,9 & 228,8 & 108,7 & 120,1 \\
\hline 7,9 & 97,72 & 39,27 & 58,45 & 13,0 & 231,9 & 110,4 & 121,5 \\
\hline 8,0 & 100,0 & 40,40 & 59,60 & 13,1 & 235,0 & 112,1 & 122,9 \\
\hline 8,1 & 102,3 & 41,57 & 60,74 & 13,2 & 238,1 & 113,8 & 124,2 \\
\hline 8,2 & 104,6 & 42,72 & 61,89 & 13,3 & 241,2 & 115,6 & 125,6 \\
\hline 8,3 & 106,9 & 43,85 & 63,05 & 13,4 & 244,3 & 117,3 & 127,0 \\
\hline 8,4 & 109,2 & 45,01 & 64,18 & 13,5 & 247,4 & 119,0 & 128,4 \\
\hline 8,5 & 111,5 & 46,19 & 65,32 & 13,6 & 250,6 & 120,8 & 129,8 \\
\hline 8,6 & 113,9 & 47,40 & 66,48 & 13,7 & 253,8 & 122,6 & 131,2 \\
\hline 8,7 & 116,2 & 48,57 & 67,64 & 13,8 & 257,0 & 124,4 & 132,6 \\
\hline 8,8 & 118,5 & 49,75 & 68,79 & 13,9 & 260,1 & 126,2 & 134,0 \\
\hline 8,9 & 120,9 & 50,96 & 69,94 & 14,0 & 263,3 & 128,0 & 135,4 \\
\hline 9,0 & 123,3 & 52,20 & 71,1 & 14,1 & 266,6 & 129,8 & 136,8 \\
\hline 9,1 & 125,7 & 53,40 & 72,27 & 14,2 & 269,8 & 131,6 & 138,2 \\
\hline 9,2 & 128,0 & 54,61 & 73,42 & 14,3 & 273,0 & 133,5 & 139,6 \\
\hline 9,3 & 130,4 & 55,84 & 74,57 & 14,4 & 276,3 & 135,3 & 141,0 \\
\hline 9,4 & 132,8 & 57,10 & 75,73 & 14,5 & 279,6 & 137,2 & 142,4 \\
\hline 9,5 & 135,3 & 58,36 & 76,91 & 14,6 & 283,0 & 139,1 & 143,9 \\
\hline 9,6 & 137,7 & 59,68 & 78,08 & 14,7 & 286,4 & 141,1 & 145,3 \\
\hline 9,7 & 140,1 & 60,87 & 79,27 & 14,8 & 289,7 & 142,9 & 146,8 \\
\hline 9,8 & 142,7 & 62,22 & 80,46 & 14,9 & 293,0 & 144,8 & 148,2 \\
\hline 9,9 & 145,2 & 63,54 & 81,67 & 15,0 & 296,5 & 146,8 & 149,7 \\
\hline 10,0 & 147,7 & 64,86 & 82,87 & 15,1 & 300,0 & 148,8 & 151,2 \\
\hline 10,1 & 152,9 & 66,22 & 84,08 & 15,2 & 303,4 & 150,8 & 152,6 \\
\hline 10,2 & 152,9 & 67,56 & 85,30 & 15,3 & 306,9 & 152,8 & 154,1 \\
\hline 10,3 & 155,4 & 8,90 & 86,51 & 15,4 & 310,3 & 154,8 & 155,6 \\
\hline 10,4 & 158,0 & 70,25 & 87,72 & 15,5 & 313,9 & 156,9 & 157,0 \\
\hline 10,5 & 160,6 & 71,63 & 88,95 & 15,6 & 317,5 & 158,9 & 158,6 \\
\hline 10,6 & 163,2 & 73,00 & 90,19 & 15,7 & 321,1 & 161,0 & 160,1 \\
\hline 10,7 & 165,8 & 74,42 & 91,40 & 15,8 & 324,6 & 163,0 & 161,6 \\
\hline 10,8 & 168,5 & 75,86 & 92,65 & 15,9 & 328,3 & 165,2 & 163,1 \\
\hline 10,9 & 171,2 & 77,33 & 93,92 & 16,0 & 331,9 & 167,3 & 164,6 \\
\hline 11,0 & 173,9 & 78,75 & 95,19 & & & & \\
\hline
\end{tabular}




\section{Контрольные вопросы и задания}

1. Как меняется вязкость в зависимости от температуры?

2. Что называют индексом вязкости и как действуют присадки, улучшающие вязкостно-температурные свойства масел?

3. Как определяют индекс вязкости?

4. Как влияет температура на окисление и разрушение углеводородов масел?

5. В чем сущность процесса лако- и нагарообразования в двигателях

6. Каковы назначение и механизм действия моющих присадок?

7. Как влияет качество масел на механический и коррозионный износ?

8. Почему недопустимо наличие абразивных механических примесей в смазочных материалах?

9. Как классифицируют моторные масла по эксплуатационным свойствам?.

10. Расскажите о классификации моторных масел по вязкости.

11. Как маркируют моторные масла?

12. Какие моторные масла применяют для бензиновых двигателей?

13. Какие моторные масла используют в дизелях? 


\section{Лабораторная работа № 9 \\ ОПРЕДЕЛЕНИЕ ПРЕДЕЛА ПРОЧНОСТИ \\ НА СДВИГ ПЛАСТИЧНОЙ СМАЗКИ}

1.1. Цель работы: закрепить знания по составу и эксплуатационным свойствам пластичных смазок, приобрести навыки по измерению и расчету предела прочности на сдвиг пластичной смазки.

\section{2. Задачи работы:}

ознакомиться с методикой определения предела прочности на сдвиг, с измерительным оборудованием и приборами;

провести подготовку пластичной смазки и оборудования к лабораторным испытаниям;

провести измерения предела прочности на сдвиг пластичной смазки;

вычислить значение предела прочности на сдвиг;

1.3. Оборудование и приборы - пластометр К-2.

1.4. Объект испытания - пластичные смазки.

\section{5. Порядок выполнения работы}

Определение предела прочности на сдвиг пластичной смазки следует проводить в соответствии с ГОСТ 7143-73 «Смазки пластичные. Метод определения предела прочности и термоупрочнения».

\section{Общие сведения}

Пластичные смазки проявляют свойства, присущие твердому телу в состоянии покоя или при приложении к их поверхности небольшой силы. Они не текут и сохраняют свою форму. Когда приложенная к смазке сила превышает некоторое значение, пластичная смазка начинает течь. 
Предел прочности характеризуется минимальным напряжением сдвига, при котором в пластичной смазке разрушается структурный каркас и она приобретает текучесть. Пределом прочности на сдвиг пластичной смазки называется критическое значение силы, отнесенное к единице площади сдвига слоев смазки. За единицу измерения этой величины принят паскаль (Па).

Значение предела прочности на сдвиг определяется в основном качеством загустителя и его концентрацией в пластичной смазке. Предел прочности зависит от температуры: при повышении температуры он снижается. Температура, при которой предел прочности становится равным нулю, является истинной температурой перехода смазки из пластичного в жидкое состояние и характеризует предел применения пластичной смазки.

Чем выше предел прочности на сдвиг пластичной смазки, тем она лучше удерживается на поверхности. Чтобы смазка не стекала с трущихся поверхностей под действием центробежной силы в подшипниках качения, предельное напряжение сдвига должно быть не менее 150 ... 180 Па.

Предел прочности на сдвиг пластичных смазок определяют по методу Климова на пластометре К-2. Метод основан на измерении давления, при котором происходит сдвиг смазки в капилляре пластометра К-2.

Прибор рассчитан на проведение измерений при давлениях до $5 \mathrm{kтc} / \mathrm{cm}^{2}$. Давление в приборе создается за счет термического расширения жидкости в резервуаре, нагреваемом электропечью.

В таблице 15 приведены данные о пределе прочности на сдвиг некоторых пластичных смазок, применяемых в сельском хозяйстве.

\section{Проведение испытаний}

Пластометр К-2 состоит из основания со стойкой, по которой вертикально перемещается электропечь 8 (рисунок 38 ). 
Таблица 15 - Пределы прочности пластичных смазок

\begin{tabular}{|l|c|c|}
\hline \multirow{2}{*}{ Смазка } & Предел прочности на сдвиг, Па, при температуре \\
\cline { 2 - 3 } & $20^{\circ} \mathrm{C}$ & $50^{\circ} \mathrm{C}$ \\
\hline Солидол С & $300 \ldots 700$ & $200 \ldots .350$ \\
Пресс-солидол С & $70 \ldots 200$ & $100 \ldots 180$ \\
Графитная УСсА & $300 \ldots 700$ & $200 \ldots 300$ \\
Литол-24 & $600 \ldots 1200$ & $400 \ldots 600$ \\
Фиол-1 & $250 \ldots .350$ & $200 \ldots .250$ \\
Униол-1 & $200 . .500$ & $250 \ldots .400$ \\
ЦИАТИМ-221 & $250 \ldots 450$ & $120 \ldots 300$ \\
ЦИАТИМ-201 & $350 \ldots . .550$ & $250 \ldots 350$ \\
Смазка № 158 & $150 . .400$ & $150 \ldots 300$ \\
КСБ & $300 \ldots 800$ & $200 \ldots 400$ \\
\hline
\end{tabular}
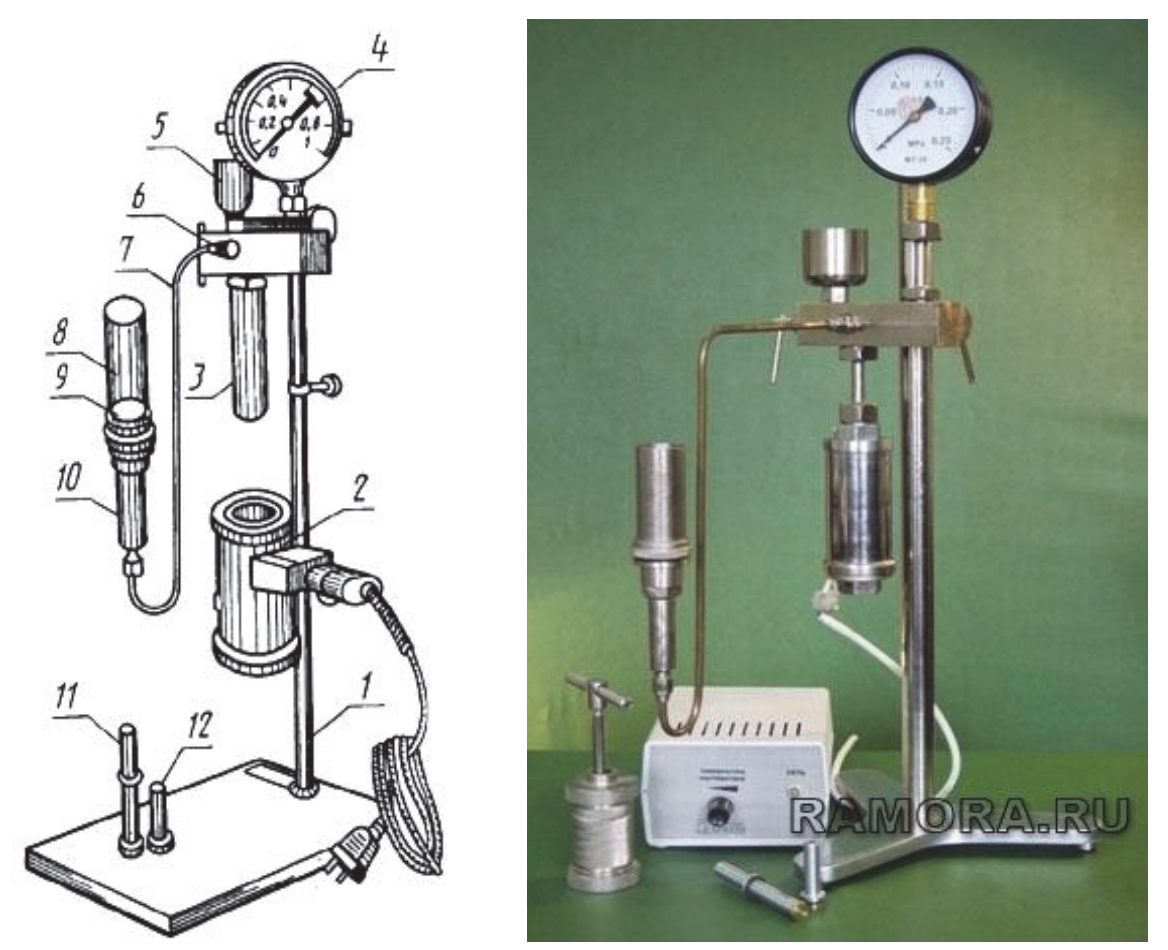

Рисунок 38 - Пластометр К-2: 1 - основание со стойкой;

2 - электропечь; 3 - резервуар с маслом; 4 - манометр; 5 - воронка для добавления масла; 6 - кран; 7 - трубка для присоединения корпуса к крану; 8 - защитное стекло; 9 - гайка для крепления капилляра в корпусе $10 ; 11$ - капилляр с оправой (длинный - 100 мм); 12 - капилляр с оправой (короткий - 50 мм)

Электропечь нагревает резервуар 3 с маслом для повышения давления, которое контролируют по манометру 4. Воронка 5 служит для добавления 
масла в прибор, кран 6 - для сообщений воронки с внутренней полостью прибора. Корпус 3 трубкой соединен с внутренней полостью прибора. Внутри корпуса 10 находится капилляр. В комплект прибора входят два капилляра, один - длиной 100 мм, другой - длиной 50 мм. Короткий капилляр применяется в том случае, когда при испытании на длинном капилляре давление превышает допустимое для манометра.

Мешалка для перемешивания смазки представляет собой полый цилиндр со съемными крышками. Через верхнюю крышку в цилиндр вставлен поршень в отверстиями.

Все внутренние полости прибора К-2, включая манометр, заполнены маловязким маслом с целью полного вытеснения воздуха.

\section{6. Подготовка объекта}

Перемешанной смазкой заполняют обе половинки желоба капилляра. Осторожно, чтобы не вызвать сдвига смазки, соединяют их и надевают кольцо. Смазывают испытуемой смазкой наружную поверхность капилляра и вставляют его в оправку, медленно вращая и передвигая вдоль оси. На нижний обрез буртика оправки надевают резиновую прокладку и устанавливают оправку на выступ в корпусе пластометра.

Пластометр заполняют маслом, для чего открывают кран воронки с маслом и держат его открытым до тех пор, пока уровень масла в корпусе не достигнет верхнего обреза буртика оправки. Закрепляют оправку в корпусе гайкой, на верхней части корпуса устанавливают защитное стекло.

\subsection{1. Методика определения}

Включают электропечь, обогревающую резервуар с маслом, и наблюдают за манометром. Скорость повышения давления в системе должна быть не более

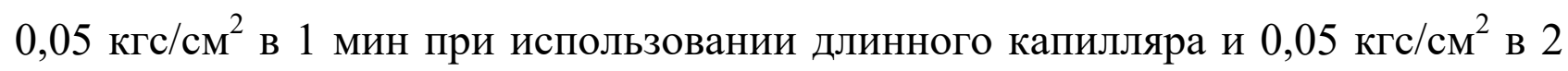
мин при использовании короткого. Скорость повышения давления регулируют, 
поднимая и опуская вдоль резервуара с маслом электропечь и, соответственно, увеличивая или уменьшая площадь нагревания.

После того как давление в системе, достигнув некоторого максимума, начинает снижаться, включают электропечь, открывают кран воронки и медленно вынимают оправку с капилляром из корпуса манометра, после чего кран закрывают.

В момент окончания опыта из капилляра выдавливается смазка, что можно наблюдать через защитное стекло.

\subsection{2. Обработка результатов измерений}

Предел прочности $\tau$ (Па) испытуемой пластичной смазки вычисляют по формуле:

$$
\tau=\operatorname{pr}(2 \times l) \times 100000
$$

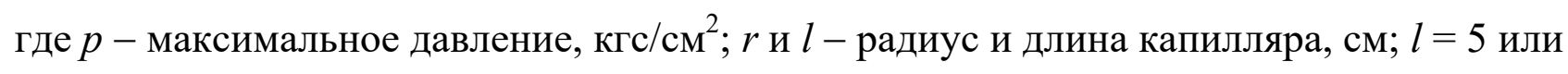
10 см. За результат испытаний принимают среднее арифметическое двух параллельных определений.

\section{Контрольные вопросы и задания}

1. Каков состав пластичных смазок?

2. Назовите эксплуатационные свойства пластичных смазок.

3. На какие группы по назначению делят смазки?

4. Как обозначают пластичные смазки?

5. Что характеризует предел прочности на сдвиг пластичной смазки?

6. Какой прибор используют для определения прочности на сдвиг? 


\section{Лабораторная работа № 10 ОПРЕДЕЛЕНИЕ ПЕНЕТРАЦИИ ПЛАСТИЧНОЙ СМАЗКИ}

1.1. Цель работы: закрепить знания по составу и эксплуатационным свойствам пластичных смазок, приобрести навыки по измерению и расчету пенетрации пластичной смазки.

\section{2. Задачи работы:}

ознакомиться с методикой определения пенетрации пластичной смазки, с измерительным оборудованием и приборами;

провести подготовку пластичной смазки и оборудования к лабораторным испытаниям;

провести измерения пенетрации пластичной смазки;

вычислить значение пенетрации.

1.3. Оборудование и приборы - пенетрометр ПН-1ЖВ.

1.4. Объект испытания - пластичная смазка.

\section{5. Порядок выполнения работы}

Определение пенетрации пластичных смазок следует проводить в соответствии с ГОСТ 32331-2013 «Смазки пластичные. Определение пенетрации с использованием пенетрометра с конусом на одну четверть и половину шкалы».

\section{Общие сведения}

Пенетрация характеризует консистенцию или степень мягкости пластичных смазок. Пенетрацию (число проницаемости) определяют на лабораторном пенетрометре ЛП глубиной погружения в испытуемую смазку стандартного по форме и массе тела (конуса или иглы) за 5 с при заданной нагрузке и температуре. Число проницаемости (пенетрации) выражается целым числом десятых долей миллиметра глубины погружения конуса или иглы в 
смазку. Изменение числа пенетрации пластичных смазок при хранении в условиях эксплуатации указывает на изменение ее структуры. Такую смазку необходимо быстрее использовать.

В таблице 16 приведены значения чисел пенетрации при $25{ }^{\circ} \mathrm{C}$ и коллоидной стабильности (\%) для некоторых пластичных смазок, применяемых в сельском хозяйстве.

Таблица 16 - Пенетрация пластичных смазок

\begin{tabular}{|l|c|c|}
\hline \multicolumn{1}{|c|}{ Смазка } & Пенетрация при $25^{\circ} \mathrm{C}$ & Коллоидная стабильность, \% \\
\hline Солидол С & $270 \ldots .330$ & $1 \ldots . .5$ \\
Пресс-солидолС & $330 \ldots 360$ & $2 \ldots 10$ \\
Графитная УСсА & $250 \ldots .270$ & $0,5 \ldots 4$ \\
Литол-24 & $220 \ldots .250$ & $8 \ldots 12$ \\
Фиол-1 & $310 \ldots 340$ & $15 \ldots .20$ \\
Униол-1 & $280 \ldots 320$ & $2 \ldots 7$ \\
ЦИАТИМ-221 & $280 \ldots 320$ & $4 \ldots 7$ \\
ЦИАТИМ-201 & $290 \ldots 320$ & $16 \ldots .30$ \\
Лита & $290 \ldots 320$ & $15 \ldots .20$ \\
Смазка № 158 & 305 & $8 \ldots 15$ \\
КСБ & $245 \ldots .275$ & $4 \ldots 8$ \\
\hline
\end{tabular}

\section{Проведение испытаний}

Лабораторный пенетрометр ЛП состоит из штатива с плитой, на которой установлены круглый уровень и столик(рисунок 39).

Его положение по высоте можно регулировать. На штативе укреплен кронштейн с плунжером, индикатор и зеркало. Плунжер свободно перемещается в направляющей втулке и фиксируется с помощью зажима. Пусковая кнопка служит для освобождения плунжера. К плунжеру прикреплены игла с грузом и конус. Индикатор состоит из кремальеры, с осью шестерни которой соединена стрелка. Стрелка соединяется с осью шестерни на конусе поджимаемой пружиной и может устанавливаться на нуль при любом положении рейки кремальеры. 


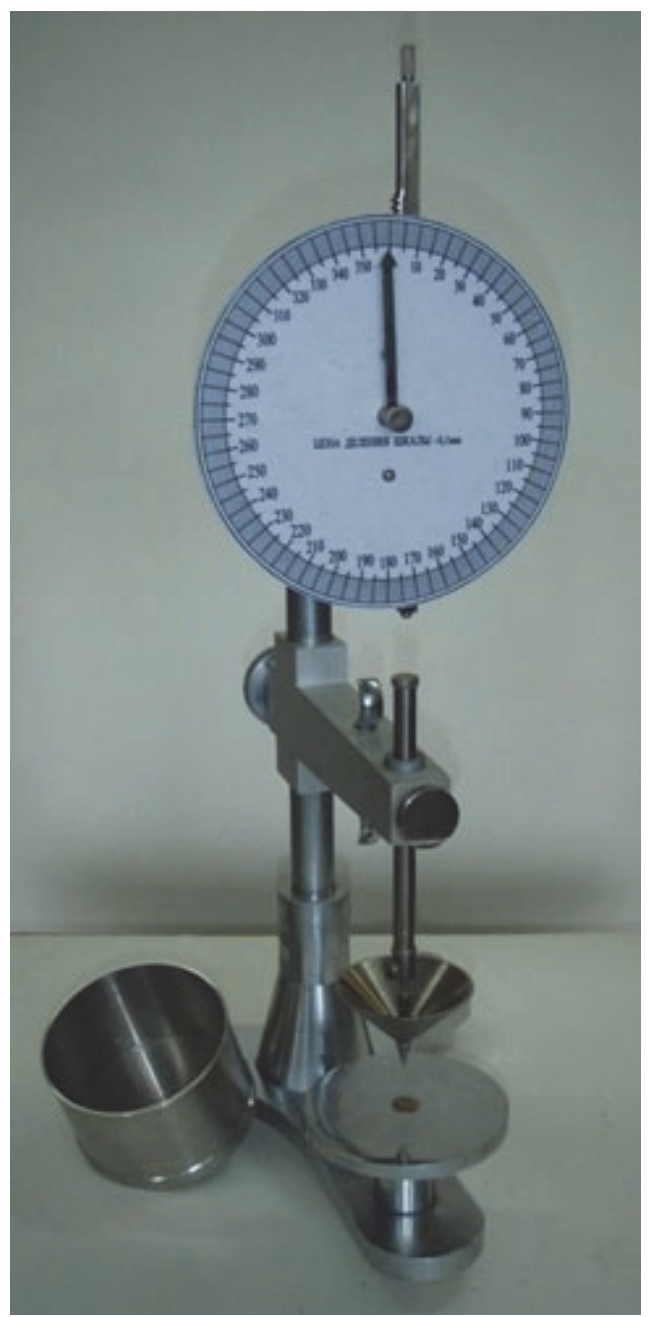

Рисунок 39 - Пенетрометр ПН-1ЖВ: 1 - конус; 2 - пусковая кнопка; 3 кремальера; 4 - индикатор; 5 - стрелка

\section{6. Подготовка объекта}

Стеклянный стакан с тщательно перемешанной испытуемой смазкой помещают на столик и выравнивают поверхность смазки. Избыток смазки снимают. С помощью зажима перемещают кронштейн по стойке так, чтобы наконечник конуса коснулся поверхности смазки. Положение наконечника конуса контролируют с помощью зеркала. При этом необходимо предотвратить возможность соприкосновения конуса со стенкой стакана. Рейку, снабженную сферическим наконечником, перед измерением подводят к установленному и зафиксированному зажимом плунжеру, после чего стрелку устанавливают на нуль по шкале (360 делений ценой 0,1 мм). При установке индикатора следят за 
тем, чтобы осталась необходимая длина хода рейки кремальеры (30...35 мм). Это достигается смещением индикатора вдоль стойки.

\subsection{1. Методика определения}

Далее одновременно включают секундомер и нажимают пусковую кнопку 2. Конус свободно погружается в смазку в течение 5 с, после чего отпускают кнопку, прекращая погружение. Затем снова отпускают рейку до соприкосновения с плунжером, при этом также передвигают стрелку 5 индикатора.

После отсчета показаний по шкале индикатора приподнимают кремальеру и плунжер с конусом, тщательно очищают конус от смазки, выравнивают поверхность испытуемой смазки в стаканчике и повторяют опыт.

\subsection{2. Обработка результатов измерений}

За результат испытания принимают среднее арифметическое четырех последовательных определений.

\section{Контрольные вопросы и задания}

1. Что понимают под пенетрацией пластичной смазки?

2. Как классифицируются пластичные смазки?

3. Назовите марки смазок общего назначения.

4. Расскажите о значении вязкости смазки.

5. Как получают пластичные смазки?

6. Какой прибор используют для определения пенетрации?

7. Какой состав и область применения солидолов и смазки Литол- $24 ?$ 


\section{Лабораторная работа № 11 \\ ОПРЕДЕЛЕНИЕ КОЛЛОИДНОЙ СТАБИЛЬНОСТИ \\ ПЛАСТИЧНОЙ СМАЗКИ}

1.1. Цель работы: закрепить знания по составу и эксплуатационным свойствам пластичных смазок, приобрести навыки по измерению и расчету коллоидной стабильности пластичной смазки.

\section{2. Задачи работы:}

ознакомиться с методикой определения коллоидной стабильности пластичной смазки, с измерительным оборудованием и приборами;

провести подготовку пластичной смазки и оборудования к лабораторным испытаниям;

провести измерения коллоидной стабильности пластичной смазки;

вычислить значение коллоидной стабильности.

1.3. Оборудование и приборы - прибор КСА.

1.4. Объект испытания - пластичная смазка.

\section{5. Порядок выполнения работы}

Определение коллоидной стабильности пластичных смазок следует проводить в соответствии с ГОСТ 7142-74 «Смазки пластичные. Методы определения коллоидной стабильности».

\section{Общие сведения}

Пластичные смазки представляют собой коллоидные системы, состоящие из дисперсной среды и дисперсной фазы. Дисперсной средой служит жидкое минеральное масло, а дисперсной фазой - загуститель. В состав пластичных смазок входит $80 \ldots 90$ \% минерального масла и $10 . .20$ \% загустителя (различные мыла или твердые углеводороды), а также вода для повышения их коллоидной 
стабильности. Иногда для улучшения качества и придания специфических свойств к смазкам добавляют различные присадки и наполнители, например, графит.

При хранении или эксплуатации из пластичной смазки не должно выделяться масло, т.е. смазка должна обладать коллоидной стабильностью. Под коллоидной стабильностью понимают стойкость пластичной смазки против необратимого разрушения. У большинства пластичных смазок с течением времени выделяется жидкое масло. Это явление усиливается под действием высокой температуры, давления и перемешивания. Коллоидная стабильность возрастает с увеличением количества загустителя в смазке и падает с понижением вязкости минерального масла. Смазки с низкой коллоидной стабильностью (например, смазка ЦИАТИМ-201) расфасовывают в мелкую тару.

Испытания проводят в приборе КСА при заданных нагрузках, времени и температуре. Чем больше отпрессовывается из пластичной смазки масла, тем ниже ее коллоидная стабильность.

\section{Проведение испытаний}

Для определения коллоидной стабильности служит прибор КСА (рисунок 40).

Он состоит из штатива с плитой, на которой установлен круглый уровень и столик. На стойке штатива укреплен кронштейн, в котором размещен шток с двумя выемками для крепления груза. Металлический шарик диаметром 8 мм служит для передачи давления на хвостовик поршня. На столик устанавливают чашечку 3 для испытуемой смазки, в которую вставлен поршень 4. Чашечка снабжена втулкой для вывода хвостовика поршня. На хвостовике поршня находится лыска для предотвращения создания вакуума над поршнем. Масса штока, шарика, поршня и груза составляет 1 кг. 


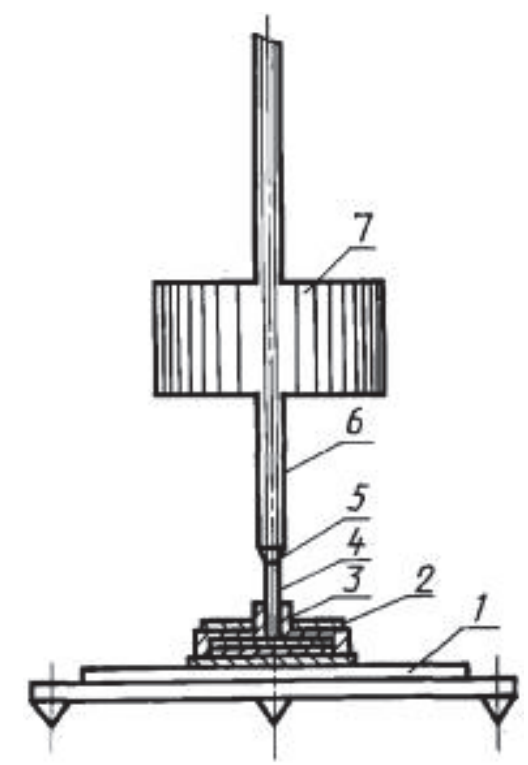

Рисунок 40 - Схема прибора КСА для определения коллоидной стабильности: 1 - кронштейн; 2 - стальная шайба; 3 - чашечка; 4 - поршень;

$$
5 \text { - шарик; } 6 \text { - шток; } 7 \text { - груз }
$$

\section{6. Подготовка объекта}

Чашечку с поршнем взвешивают на аналитических весах, затем в нее вмазывают шпателем испытуемую смазку, не допуская образования пузырьков воздуха и пустот, взвешивают и вычисляют массу смазки, взятой на испытание. Один кружок фильтровальной бумаги смачивают маслом, отжимают между листами фильтровальной бумаги и взвешивают. Стекло со стопкой фильтровальной бумаги (7...9 кружков) помещают на столике штатива. На смазку в чашечке кладут пропитанный маслом кружок фильтровальной бумаги так, чтобы между бумагой и смазкой не было пустот, и ставят чашечку на стопку фильтровальной бумаги, положенную на стекло.

\subsection{1. Методика определения}

В лунку хвостовика поршня помещают шарик, передающий давление. Нажимают пусковую кнопку, освобождают шток и опускают его до соприкосновения с шариком. На шток надевают груз, нажимают пусковую кнопку, закрепляют его скобой и отмечают время начала испытания. По 
истечении 30 мин взвешивают чашечку со смазкой и кружком фильтровальной бумаги.

\subsection{2. Обработка результатов измерений}

Количество масла $x$ (\%), выделившегося после опрессовывания пластичной смазки, вычисляют по формуле

$$
x=\frac{\left(m_{1}-m_{2}\right) \times 100}{m},
$$

где $m_{1}$ и $m_{2}$ - массы чашечки со смазкой и пропитанным маслом кружком фильтровальной бумаги до и после испытания, г; $m$ - масса смазки, взятой для испытания, г.

За результат испытаний принимают среднее арифметическое двух параллельных определений.

\section{Контрольные вопросы и задания}

1. Что понимают под коллоидной стабильностью пластичной смазки?

2. Какой прибор используют для определения коллоидной стабильности пластичной смазки?

3. Назовите состав пластичных смазок.

4. Что используют в качестве дисперсной среды и дисперсной фазы?

5. Как изменяются эксплуатационные свойства при хранении пластичных смазок?

6. Каково назначение консервационных смазок? 


\section{Лабораторная работа № 12 \\ ОПРЕДЕЛЕНИЕ ПЛОТНОСТИ НЕФТЕПРОДУКТОВ}

1.1. Цель работы: закрепить знания по оценке качества и физических свойств нефтепродуктов, абсолютной и относительной плотности вещества, приобрести навыки по измерению и расчету плотности нефтепродуктов.

\section{2. Задачи работы:}

ознакомиться с методикой определения плотности нефтепродуктов, с измерительным оборудованием и приборами;

провести подготовку нефтепродуктов и оборудования к лабораторным испытаниям;

провести измерения плотности нефтепродуктов;

вычислить значение плотности нефтепродуктов.

1.3. Оборудование и приборы: ареометры (нефтеденсиметры), для нефти AНТ-1, АНТ-2, АН, ареометры общего назначения АОН-1, жидкостной термостат.

1.4. Объект испытания - нефтепродукты.

\section{5. Порядок выполнения работы}

Определение плотности при $20{ }^{\circ} \mathrm{C}$ производится по ГОСТ 3900-85 «Нефть и нефтепродукты. Методы определения плотности», определение плотности при $15{ }^{\circ} \mathrm{C}$ производится по ГОСТ Р 51069-97 «Нефть и нефтепродукты. Метод определения плотности, относительной плотности и плотности в градусах API ареометром»

\section{Общие сведения}

Плотность - это масса вещества, заключенная в единице объема. 
Величина плотности определяется как групповым и углеводородным составом нефтепродукта, так и внешними факторами - температурой, давлением. Нефтепродукты более тяжелого фракционного состава имеют и большую плотность, с повышением температуры плотность снижается.

Значение плотности необходимо при пересчете объема нефтепродукта в массу. Кроме того, по плотности можно определить конкретный нефтепродукт при сравнении нескольких сортов или марок.

Плотность нормируется в пределах:

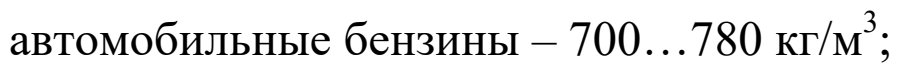

дизельные топлива $-800 \ldots 850 \mathrm{\kappa г} / \mathrm{M}^{3}$;

масла $-890 \ldots 990$ кг $/ \mathrm{M}^{3}$.

В настоящее время в ГОСТ (ТУ) на горючее нормируется два показателя качества:

плотность при $20^{\circ} \mathrm{C}$;

плотность при $15^{\circ} \mathrm{C}$.

Различают абсолютную и относительную плотность вещества.

Абсолютная плотность вещества - это масса, содержащаяся в единице объема. В системе СИ размерность плотности - кг/м². За единицу плотности принимают массу $1 \mathrm{~m}^{3}$ дистиллированной воды при температуре $4{ }^{\circ} \mathrm{C}$.

Относительная плотность вещества - отношение его массы к массе дистиллированной воды при $4{ }^{\circ} \mathrm{C}$, взятой в том же объеме. Относительная плотность - величина безразмерная.

Нефтепродукты и вода имеют неодинаковые коэффициенты расширения. В связи с этим необходимо при определении плотности указывать температуры нефтепродукта и воды, при которых проводилось определение. В РФ относительную плотность нефтепродуктов определяют при температуре $20{ }^{\circ} \mathrm{C}$. Плотность нефтепродукта может быть замерена при любой температуре, однако результат приводят к температуре $20^{\circ} \mathrm{C}$.

В соответствии с действующим стандартом плотность нефтепродукта обозначается $\rho_{4}^{20}$. Здесь цифра 20 указывает, что плотность нефтепродукта 
относят к нормальной температуре $20^{\circ} \mathrm{C}$, а цифра 4 обозначает, что плотность нефтепродукта относят к плотности воды при 4 $\mathrm{C}$, принятой за единицу.

Относительная плотность автомобильных бензинов колеблется в пределах $0,69 \ldots 0,75$, дизельного топлива $-0,82 \ldots 0,86$, а абсолютная плотность

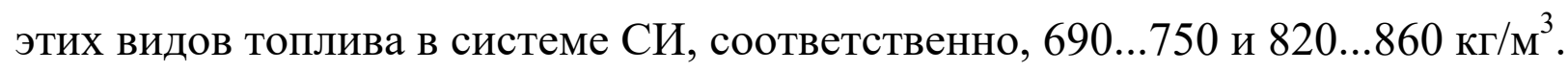

В стандартах на топливо плотность не нормируется, однако определять ее по госстандарту обязательно. Это необходимо для учета расхода и движения нефтепродуктов на нефтескладах и заправочных станциях, так как приход фиксируют в единицах массы (кг, т), а расход при заправке тракторов и автомобилей учитывается в единицах объема (л). Поэтому для пересчета топлива из единиц массы в единицы объема и обратно нужно знать плотность получаемых и отпускаемых нефтепродуктов.

Определение плотности при $20{ }^{\circ} \mathrm{C}$ производится по ГОСТ 3900-85 «Нефть и нефтепродукты. Методы определения плотности». В лабораториях горючего определение плотности при $20^{\circ} \mathrm{C}$ проводят по 1 части ГОСТ 3900-85, которая предусматривает определение плотности ареометром. Данный метод используется для определения плотности большинства горюче-смазочных материалов, применяемых на военной технике.

Сущность метода заключается в погружении ареометра в испытуемый нефтепродукт, снятии показания по шкале ареометра при температуре определения и пересчете результатов на плотность при температуре $20{ }^{\circ} \mathrm{C}$.

Определение плотности при 15 C производится по ГОСТ Р 51069-97 «Нефть и нефтепродукты. Метод определения плотности, относительной плотности и плотности в градусах API ареометром», который содержит аутентичный текст национального стандарта США ASTM D 1298 «Стандартный метод определения плотности, относительной плотности (удельного веса) или плотности в градусах API сырой нефти и жидких нефтепродуктов ареометром» с дополнительными требованиями, отражающими потребности экономики страны. 
Сущность метода заключается в следующем. Пробу доводят до заданной температуры и переносят в цилиндр. В пробу погружают соответствующий ареометр. После достижения температурного равновесия отмечают показания ареометра и температуру испытуемой пробы. При необходимости цилиндр с испытуемым продуктом помещают в термостат с заданной постоянной температурой во избежание значительной погрешности во время испытания.

Отмечают показания ареометра при температуре испытания. Затем плотность приводят к температуре $15{ }^{\circ} \mathrm{C}$ с помощью международных стандартных таблиц.

Методы определения плотности по ГОСТ 3900-85 и ГОСТ Р 51069-97 в основном сходны между собой, различия заключаются в порядке пересчета показаний ареометра к заданной температуре и в градуировке используемых ареометров.

Для анализа по ГОСТ 3900-85 используют ареометры для нефти АНТ-1, АНТ-2, АН, изготовленные по ГОСТ 18481-81. Кроме ареометров для нефти АНТ-1, АНТ-2, АН, такой же диапазон измерений имеют ареометры общего назначения АOH-1.

Для анализа по ГОСТ Р 51069-97 используют ареометры, градуированные при $15{ }^{\circ} \mathrm{C}$ в соответствии со спецификациями ASTM или Британского института стандартов.

Для испытуемого горючего подбирают ареометр с соответствующей шкалой плотности.

Цилиндр для ареометров может быть изготовлен из прозрачного стекла, пластмассы или металла. Пластмассы, применяемые для изготовления цилиндров для ареометров, должны быть стойкими к обесцвечиванию и воздействию образцов нефтепродуктов и не должны мутнеть после продолжительного воздействия солнечного света или воздействия образцов нефтепродуктов. Данным требованиям удовлетворяют цилиндры, изготовленные из фторопласта.

Для облегчения переливания цилиндр может иметь на ободке носик. Высота цилиндра должна быть такой, чтобы расстояние от дна цилиндра до 
ареометра было не менее 25 мм. Диаметр цилиндра должен не менее чем вдвое превышать диаметр корпуса ареометра.

Металлические и пластмассовые цилиндры целесообразно использовать при определении плотности вне стационарной лаборатории (например, при замерах количества горючего в резервуарах, цистернах).

Для определения температуры пробы используются термометры ртутные стеклянные. Термометр должен быть калиброван на полное погружение.

Для приведения температуры нефтепродукта к заданной температуре испытания могут использоваться жидкостные термостаты с точностью поддержания температуры $\pm 0,2{ }^{\circ} \mathrm{C}$. В настоящее время отечественной промышленностью выпускаются различные модификации жидкостных термостатов для определения плотности нефтепродуктов с точностью поддержания температуры $\pm 0,1{ }^{\circ} \mathrm{C}$. Наиболее предпочтительны модели с прозрачными боковыми стенками. Общий вид такого термостата представлен на рисунке 41.

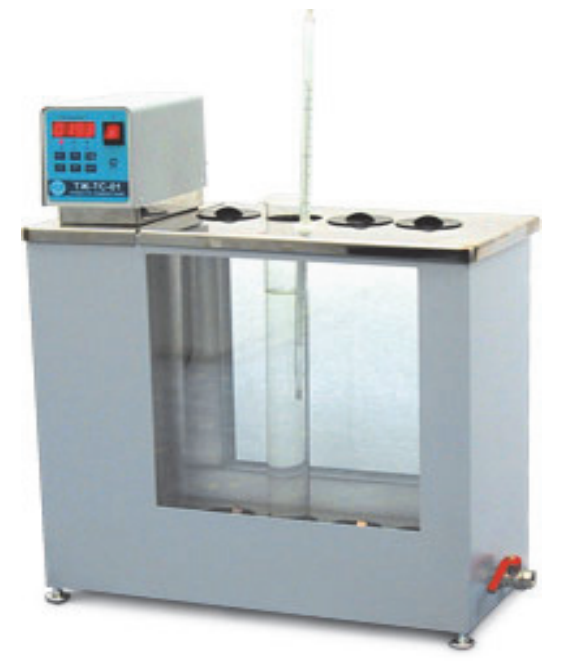

Технические характеристики термостатов для определения плотности:

1. Пределы регулирования температуры:

$\checkmark \quad$ без внешнего охлаждения $+30 \ldots+100{ }^{\circ} \mathrm{C}$;

$\checkmark \quad$ с охлаждением водопроводной водой

$+15 \ldots+100{ }^{\circ} \mathrm{C}$;

$\checkmark \quad$ с внешним криостатом $0 \ldots+100^{\circ} \mathrm{C}$.

2.Точность поддержания температуры $\pm 0,1^{\circ} \mathrm{C}$

3. Количество мест под цилиндры 4 - 6

4. Объем рабочей ванны $33-80$ л

Рисунок 41 - Термостат для определения плотности

Плотность нефтепродуктов определяют с помощью ареометров (нефтеденсиметров), гидростатических весов Вестфаля и пикнометров. В практике работы нефтескладов обычно используют нефтеденсиметры. 
Нефтеденсиметр представляет собой стеклянный пустотелый поплавок, внизу которого находится балласт, а сверху - тонкая трубка со шкалой. Некоторые нефтеденсиметры снабжены внутренним термометром. На рисунке 42 показан прибор для определения плотности нефтепродуктов.

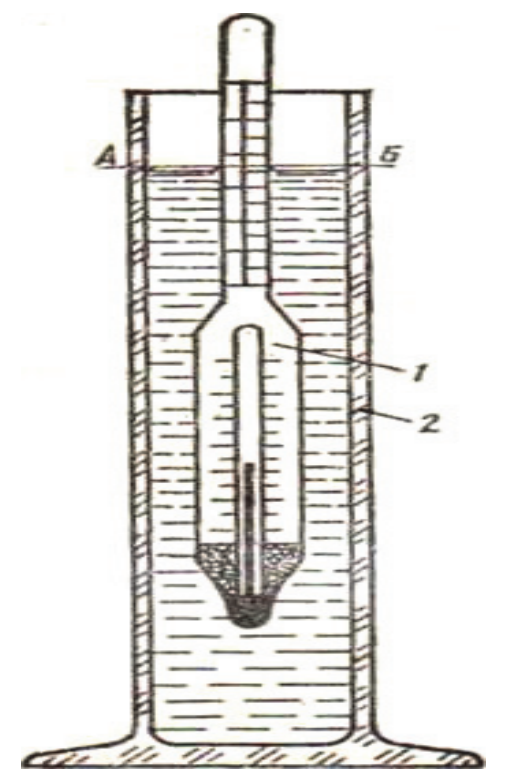

Рисунок 42 - Прибор для определения плотности нефтепродуктов:

1 - нефтеденсиметр; 2 - стеклянный цилиндр

\section{Проведение испытаний}

\section{6. Подготовка объекта}

В стеклянный цилиндр осторожно наливают испытуемый нефтепродукт, температура которого может отклоняться от температуры окружающей среды не более чем на $\pm 5{ }^{\circ} \mathrm{C}$.

\subsection{1. Методика определения}

Чистый и сухой нефтеденсиметр медленно и осторожно опускают в нефтепродукт, держа его за верхний конец. Во избежание повреждения нефтеденсиметр вводят до дна цилиндра или до погружения всей шкалы, а затем убирают руку.

После того как нефтеденсиметр установится и прекратятся его колебания, снимают показания по верхнему краю мениска. При отсчете глаз должен 
находиться на уровне мениска (рисунок 16, линия AB), а нефтеденсиметр не должен касаться стенок цилиндра.

Одновременно с отсчетом показания по шкале нефтеденсиметра устанавливают температуру нефтепродукта по внутреннему или дополнительному термометру, вводя его в нефтепродукт рядом с нефтеденсиметром.

При отсчете по шкале нефтеденсиметра получают плотность нефтепродукта при температуре испытания. Значением этой плотности пользуются для определения объемного количества нефтепродукта (или для обратного пересчета).

\subsection{2. Обработка результатов измерений}

Замеренную плотность приводят к плотности при нормальной температуре $\rho_{4}^{20}$. по формуле

$$
\rho_{4}^{20}=\rho_{4}^{\mathrm{t}}+\gamma \times(t-20),
$$

где $\rho_{4}^{\mathrm{t}}$. - плотность испытуемого нефтепродукта при температуре испытания; $\gamma$ - средняя температурная поправка плотности (таблица 17); $t$ - температура испытания, ${ }^{\circ} \mathrm{C}$.

Эта формула была предложена Д. И. Менделеевым. Она показывает, что плотность нефтепродукта уменьшается с повышением температуры и увеличивается с ее понижением.

Определение плотности вязких нефтепродуктов. Смазочные масла обладают высокой вязкостью, что не позволяет непосредственно измерить их плотность с помощью нефтеденсиметра. Поэтому вязкие нефтепродукты разбавляют керосином $(1: 1)$ известной плотности. С помощью нефтеденсиметра определяют плотность приготовленной смеси. Плотность $\rho$ испытуемого вязкого нефтепродукта вычисляют по формуле:

$$
\rho=2 \rho_{1}-\rho_{2},
$$

где $\rho_{1}$ - плотность смеси; $\rho_{2}$ - плотность разбавителя (керосина). 
Таблица 17 - Величина средних температурных поправок для нефтепродуктов

\begin{tabular}{|c|c|c|c|}
\hline $\begin{array}{c}\text { Относительная } \\
\text { плотность }\end{array}$ & $\begin{array}{c}\text { Температурная } \\
\text { поправка } \gamma \text { на } 1{ }^{\circ} \mathrm{C}\end{array}$ & $\begin{array}{c}\text { Относительная } \\
\text { плотность }\end{array}$ & $\begin{array}{c}\text { Температурная } \\
\text { поправка } \gamma \text { на } 1{ }^{\circ} \mathrm{C}\end{array}$ \\
\hline $0,6900 \ldots 0,6999$ & 0,000910 & $0,8500 \ldots 0,859$ & 0,000699 \\
\hline $0,7000 \ldots 0,7099$ & 0,000897 & $0,8600 \ldots 0,869$ & 0,000686 \\
\hline $0,7100 \ldots 0,7199$ & 0,000884 & $0,8700 \ldots 0,879$ & 0,000673 \\
\hline $0,7200 \ldots 0,7299$ & 0,000870 & $0,8800 \ldots 0,889$ & 0,000660 \\
\hline $0,7300 \ldots 0,7399$ & 0,000857 & $0,8900 \ldots 0,899$ & 0,000647 \\
\hline $0,7400 \ldots 0,7499$ & 0,000844 & $0,9000 \ldots 0,909$ & 0,000633 \\
\hline $0,7500 \ldots 0,7599$ & 0,000831 & $0,9100 \ldots 0,919$ & 0,000620 \\
\hline $0,7600 \ldots 0,7699$ & 0,000818 & $0,9200 \ldots 0,929$ & 0,000607 \\
\hline $0,7700 \ldots 0,7799$ & 0,000805 & $0,9300 \ldots 0,939$ & 0,000594 \\
\hline $0,7800 \ldots 0,7899$ & 0,000792 & $0,9400 \ldots 0,949$ & 0,000581 \\
\hline $0,7900 \ldots 0,7999$ & 0,000778 & $0,9500 \ldots 0,959$ & 0,000567 \\
\hline $0,8000 \ldots 0,8099$ & 0,000765 & $0,9600 \ldots 0,969$ & 0,000554 \\
\hline $0,8100 \ldots 0,8199$ & 0,000752 & $0,9700 \ldots 0,979$ & 0,000541 \\
\hline $0,8200 \ldots 0,8299$ & 0,000738 & $0,9800 \ldots 0,989$ & 0,000528 \\
\hline $0,8300 \ldots 0,8399$ & 0,000725 & $0,9900 \ldots 0,999$ & 0,000515 \\
\hline $0,8400 \ldots 0,8499$ & 0,000712 & & \\
\hline
\end{tabular}

\section{Контрольные вопросы и задания}

1. Что такое плотность вещества, как ее определяют?

2. Как определяют плотность нефтепродуктов?

3. Как зависит плотность от температуры?

4. Какие приборы используют для определения плотности нефтепродуктов?

5. В чем разница при определении плотности бензина и моторного масла?

6. Для чего вносится поправка при определении плотности вязкого нефтепродукта? 


\section{Лабораторная работа № 13 \\ ИССЛЕДОВАНИЕ КАЧЕСТВА НИЗКОЗАМЕРЗАЮЩИХ \\ ОХЛАЖДАЮЩИХ ЖИДКОСТЕЙ}

1.1. Цель работы: закрепить знания по составу и эксплуатационным свойствам охлаждающих жидкостей, приобрести навыки по измерению и расчету плотности нефтепродуктов.

\section{2. Задачи работы:}

ознакомиться с методикой определения состава антифриза, с измерительным оборудованием и приборами;

провести подготовку низкозамерзающих охлаждающих жидкостей и оборудования к лабораторным испытаниям;

провести измерение содержания этиленгликоля в антифризе и температуру его замерзания;

вычислить значение необходимой добавки воды или этиленгликоля при исправлении антифриза.

1.3. Оборудование и приборы: гидрометр, ареометр-гидрометр.

1.4. Объект испытания: низкозамерзающие охлаждающие жидкости.

\section{5. Порядок выполнения работы}

Определение параметров охлаждающих жидкостей следует проводить в соответствии с ГОСТ 28084-89 «Жидкости охлаждающие низкозамерзающие. Общие технические условия».

\section{Общие сведения}

Большая часть тепла, выделяющегося при сгорании топлива в двигателе, идет на нагрев камер сгорания и цилиндров двигателя. При очень высоких температурах стенок камер сгорания теряется мощность двигателя вследствие 
ухудшения наполнения цилиндров, ухудшаются условия смазывания, происходят детонация, калильное зажигание и другие нежелательные явления. Чтобы предотвратить перегрев деталей двигателя, их охлаждают. В качестве охлаждающих агентов в двигателях используют воздух или жидкости. Наибольшее распространение получили жидкостные системы охлаждения.

В двигателях с жидкостным охлаждением блок и головка цилиндров выполнена двойной. Между стенками образуется охлаждающая рубашка, которая заполняется жидкостью. Охлаждающая жидкость отводит тепло от стенок и головки цилиндров и передает тепло в окружающую среду через радиатор. Таким образом, охлаждающая жидкость непрерывно циркулирует в замкнутой системе охлаждения, нагреваясь в блоке и головке цилиндров и охлаждаясь в радиаторе.

Для обеспечения нормальной работы всей системы к охлаждающей жидкости предъявляют ряд требований. Жидкость должна иметь высокую теплоемкость и теплопроводность, чтобы эффективно отводить тепло. Она не должна замерзать и кипеть при всех рабочих температурах двигателя, вспениваться, вызывать коррозию металлов и сплавов, разъедать резиновые шланги и соединения системы охлаждения.

Для эксплуатации двигателей при положительных температурах воздуха самой подходящей жидкостью является вода. При отрицательных температурах во избежание замерзания воды применяют водные смеси с различными веществами (антифризами), снижающими температуру застывания автомобильных теплоносителей. Такие смеси получили название охлаждающих низкозамерзающих жидкостей.

Наибольшее распространение в качестве антифризов получили гликолевые низкозамерзающие жидкости, представляющие собой смеси этиленгликоля с водой.

Эксплуатационные свойства охлаждающих жидкостей проявляются в результате особенностей химмотологических процессов, протекающих в 
системе охлаждения, функционально связанной с системами энергообразования и смазки при эксплуатации.

Низкозамерзающие охлаждающие жидкости (антифризы) широко используются в системах охлаждения двигателей. Для автотракторных двигателей, например, применяют этиленгликолевые антифризы. Этиленгликоль $\mathrm{C}_{2} \mathrm{H}_{4}(\mathrm{OH})_{2}$ - двухатомный спирт, представляет собой ядовитую жидкость без цвета и запаха, хорошо смешивается с водой в любых

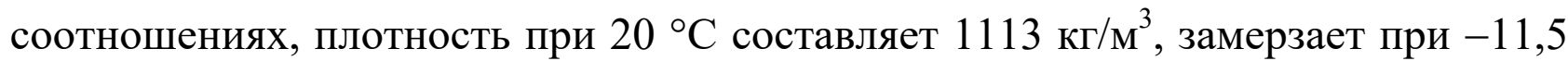
${ }^{\circ} \mathrm{C}$. Однако при смешивании этиленгликоля с водой температура застывания смеси ниже, чем каждого из компонентов (рисунки 43, 44).

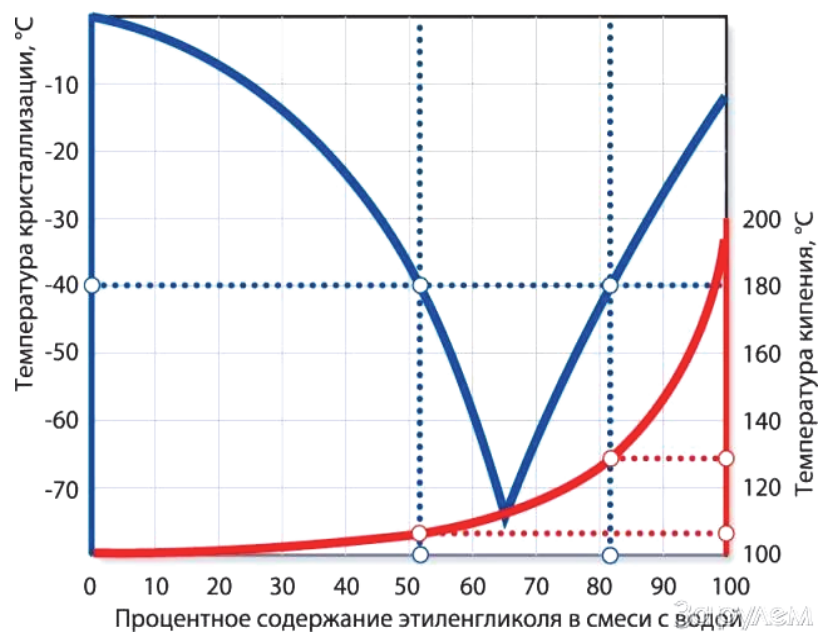

Рисунок 43 - Кривая кристаллизации водоэтиленгликолевых смесей

При смешивании этиленгликоля с водой в различных соотношениях можно получить смеси, замерзающие от 0 до $-70 \ldots 75{ }^{\circ} \mathrm{C}$.

В связи с тем, что этиленгликоль и вода обладают различной плотностью, при смешивании их в различных соотношениях меняется плотность антифриза. По плотности антифриза можно судить о его температуре замерзания.

Промышленность выпускает антифризы марок 40, 65 и концентрат марки 40к (таблица 18). 


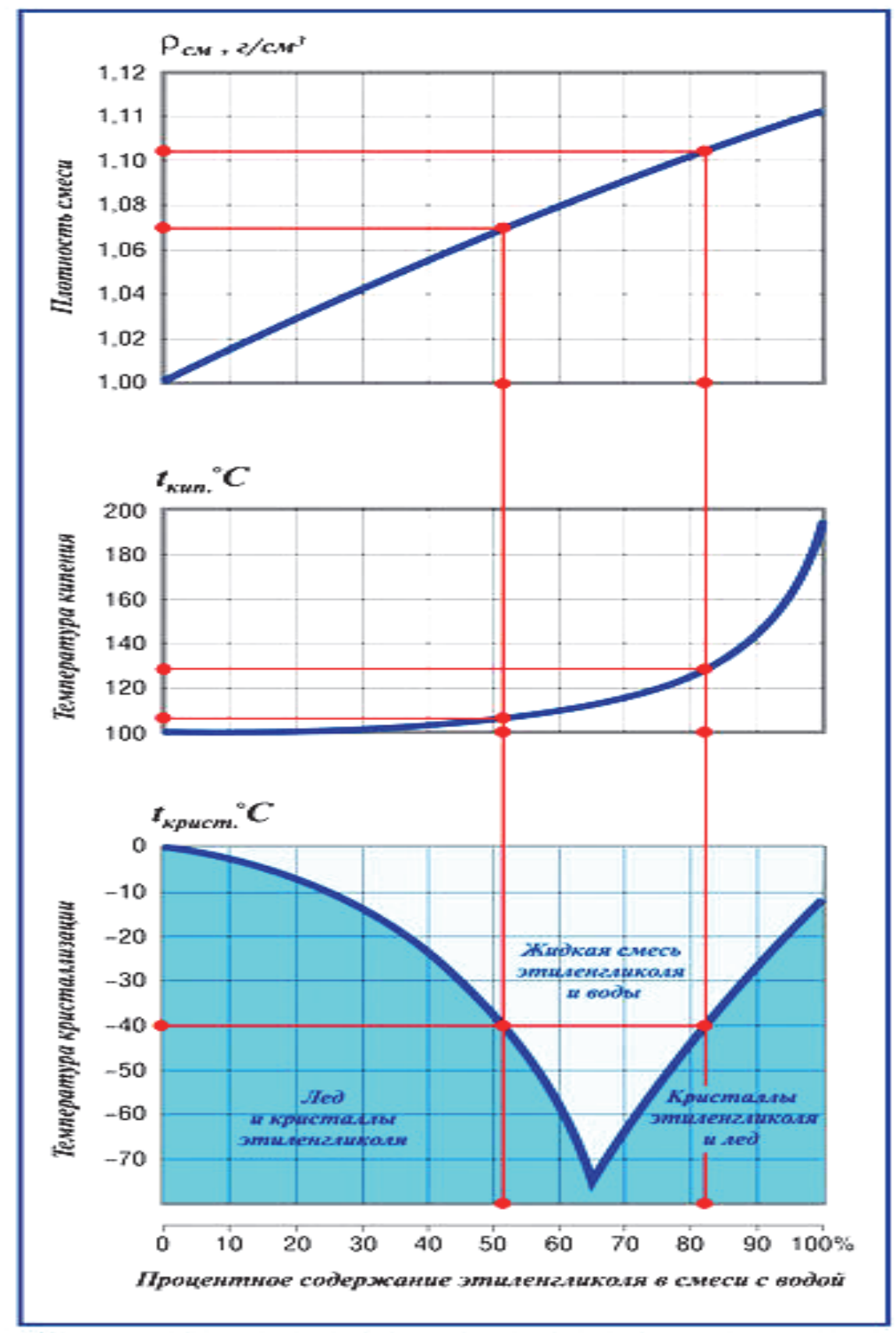

Рисунок 44 - Температура кристаллизации, температура кипения, плотность смеси этиленгликоля и воды в зависимости от содержания в ней этиленгликоля 
Таблица 18 - Низкозамерзающие охлаждающие жидкости

\begin{tabular}{|l|c|c|c|}
\hline \multirow{2}{*}{ Показатель } & \multicolumn{3}{c|}{ Норма для марки } \\
\cline { 2 - 4 } & 40 & 65 & $45 \kappa$ \\
\hline Цвет & Светло-желтый & Оранжевый & Желтый \\
\hline Плотность при $20{ }^{\circ} \mathrm{C}$, кг $/ \mathrm{m}^{3}$ & $1067 \ldots 1072$ & $1085 \ldots 1090$ & $1110 \ldots 1115$ \\
\hline Состав, \% масс. & & & \\
этиленгликоль, не менее & 52 & 64 & 94 \\
вода, не более & 47 & 35 & 5 \\
\hline Температура замерзания, ${ }^{\circ} \mathrm{C}$, не выше & -40 & -65 & - \\
\hline Температура применения, ${ }^{\circ} \mathrm{C}$ & $-40 \ldots+95$ & $-60 \ldots+95$ & - \\
\hline
\end{tabular}

Антифриз марки 40 предназначен для эксплуатации двигателей в зимнее время в средней полосе.

Антифриз марки 65 выпускается для эксплуатации двигателей в холодное время года в районах Севера и Сибири.

При смешивании 1 л концентрата 40к с 0,73 л воды получают охлаждающую жидкость марки 40.

Этиленгликоли обладают коррозионными свойствами, поэтому в низкозамерзающие охлаждающие жидкости вводят противокоррозионные присадки (декстрин, динатрийфосфат, молибденовокислый натрий). Декстрин - это углевод типа крахмала, его вводят в антифриз в количестве 1 г/л. Он защищает от коррозии алюминий, медь и свинцовооловянный припой. Некоторая часть декстрина (5..10\%) не растворяется в антифризе и находится в нем в виде коллоида. Поэтому антифриз становится несколько мутным. Декстрин при хранении может выпасть в осадок, и антифриз приобретает прозрачность. Антифриз мутный или с выпавшим осадком декстрина пригоден к употреблению.

Динатрийфосфат вводят в количестве 2,5...3,5 г/л. Он предотвращает коррозию стальных, чугунных и частично медных деталей.

Молибденовокислый натрий вводят в антифриз в количестве 7...8 г/л для предупреждения коррозии цинковых и хромовых покрытий.

Применяется также низкозамерзающая охлаждающая жидкость Тосол. Выпускают три марки этой жидкости: Тосол А-40, Тосол А-65 и Тосол А. Все 
они окрашены в голубой цвет. Тосол применяют всесезонно. В него добавляют антикоррозионные и антипенные присадки.

Тосол А представляет собой концентрат, при разбавлении которого на 50 \% дистиллированной водой получают антифриз с температурой кристаллизации $-35{ }^{\circ} \mathrm{C}$. При соответствующем разбавлении концентрата дистиллированной водой получают Тосол А - 40 с температурой замерзания $-40{ }^{\circ} \mathrm{C}$ и Тосол A-65 с температурой замерзания $-65^{\circ} \mathrm{C}$.

Марку Тосола можно определить по его плотности при $20^{\circ} \mathrm{C}$, которая для

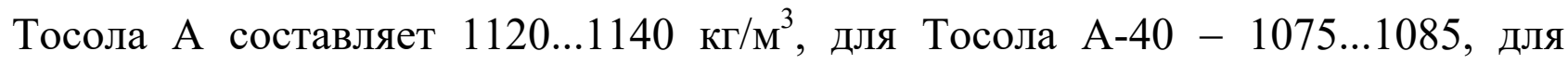

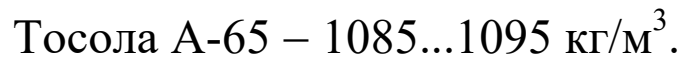

Этиленгликолевые охлаждающие жидкости - сильные яды, поэтому с ними следует работать осторожно.

\section{Проведение испытаний}

Состав антифриза определяют гидрометром. Существуют специальные ареометры-гидрометры, с помощью которых измеряют содержание этиленгликоля в антифризе и температуру его замерзания. Гидрометр (рисунок 45) представляет собой ареометр, снабженный вместо шкалы плотности двойной шкалой - содержания этиленгликоля и температуры замерзания.

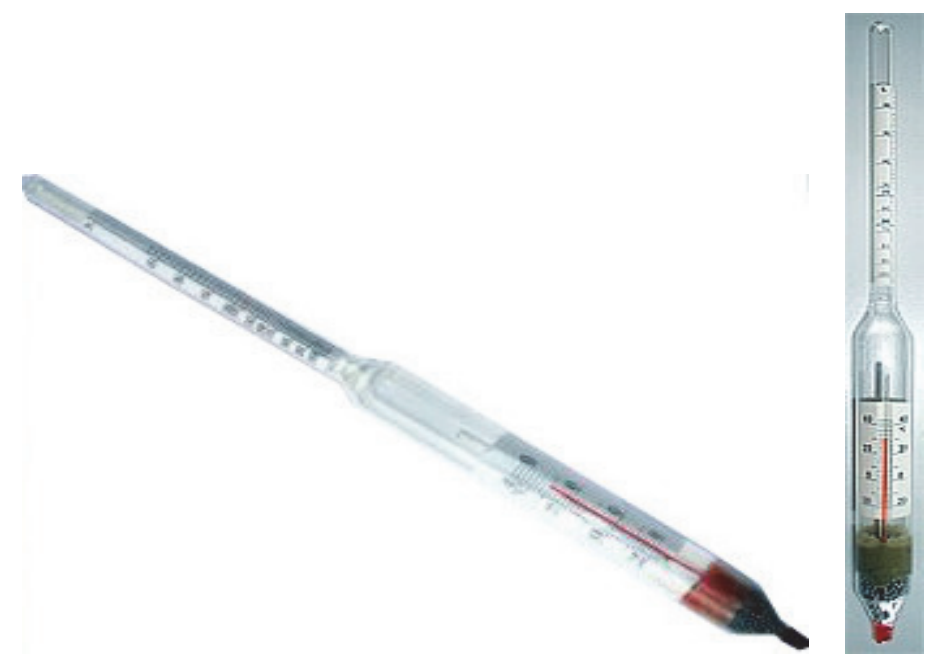

Рисунок 45 - Ареометр-гидрометр с термометром АЭГ 


\section{6. Подготовка объекта}

При проведении опыта температура антифриза должна быть $20^{\circ} \mathrm{C}$, для чего антифриз, налитый в цилиндр, выдерживают в термостатирующем устройстве в течение 15 мин. В этом случае не требуется вводить в полученный результат температурных поправок.

\subsection{1. Методика определения}

Осторожно опускают гидрометр в цилиндр с антифризом. После того как гидрометр установился, по верхней границе мениска отсчитывают на шкале значения состава антифриза и температуры застывания. Если определение состава антифриза производилось не при $20{ }^{\circ} \mathrm{C}$, то в показания гидрометра вносят поправку (таблица 19).

Таблица 19 - Поправка к показаниям гидрометра

\begin{tabular}{|c|c|c|c|c|c|c|c|c|c|}
\hline Температура испытуемого антифриза, ${ }^{\circ} \mathrm{C}$ & \multicolumn{5}{|c|}{ Содержание этиленгликоля, \% (объемн.) } \\
\hline 30 & 17 & 22 & 27 & 32 & 36 & 41 & 46 & 53 & 55 \\
\hline 20 & 20 & 25 & 30 & 35 & 40 & 45 & 40 & 55 & 60 \\
\hline 15 & 21 & 26 & 32 & 37 & 42 & 47 & 52 & 57 & 63 \\
\hline 10 & 22 & 27 & 33 & 38 & 44 & 49 & 54 & 59 & 65 \\
\hline 0 & 24 & 29 & 29 & 35 & 40 & 47 & 52 & 63 & 69 \\
\hline-10 & 26 & 31 & 37 & 43 & 50 & 56 & 62 & 67 & 73 \\
\hline
\end{tabular}

В первой графе таблицы находят температуру, при которой проводится опыт, а по горизонтальной строке - показания гидрометра при температуре опыта. Затем в том же столбце, в строке, соответствующей $20^{\circ} \mathrm{C}$, находят истинное содержание этиленгликоля в антифризе.

\subsection{2. Обработка результатов измерений}

Например, при температуре $10^{\circ} \mathrm{C}$ содержание этиленгликоля по гидрометру $38 \%$. Истинное содержание этиленгликоля (при $20{ }^{\circ} \mathrm{C}$ ) будет $35 \%$. Если в таблице отсутствуют значения температуры и показаний гидрометра, прибегают к интерполяции. После того как найден истинный состав антифриза, по шкале гидрометра определяют температуру его замерзания. 
В том случае, когда состав антифриза не соответствует нормам, приготавливают смесь требуемого качества. Необходимую добавку воды или этиленгликоля при исправлении антифриза рассчитывают по формулам:

при добавлении этиленгликоля

$$
M=\frac{(a-b) \times H}{b}
$$

при добавлении воды

$$
M=\frac{(c-d) \times H}{d},
$$

где $M$ - количество добавляемого компонента, л; $H$ - объем исходного образца, л; $a$ и $b$ - содержание воды в исходном образце и в заданной смеси, \% по объему; $c$ и $d-$ содержание этиленгликоля в исходном образце и в заданной смеси, \% (об.)

\section{Контрольные вопросы и задания}

1. Каковы состав и свойства охлаждающих низкозамерзающих жидкостей?

2. Какой состав имеет антифриз, используемый для охлаждения автомобильных двигателей?

3. Какие особенности этиленгликолевых антифризов нужно учитывать при их эксплуатации?

4. Перечислите марки этиленгликолевых антифризов.

5. Как определить добавку воды или этиленгликоля при исправлении антифриза?

6. Для чего вносится поправка к показаниям гидрометра?

7. Какие приборы используют для оценки качества антифризов? 


\section{Лабораторная работа № 14 \\ ИССЛЕДОВАНИЕ КАЧЕСТВА ТОРМОЗНЫХ ЖИДКОСТЕЙ}

1.1. Цель работы: закрепить знания по составу и эксплуатационным свойствам тормозных жидкостей, приобрести навыки по оценке качественных параметров тормозных жидкостей.

\section{2. Задачи работы:}

ознакомиться с методикой исследования качественных параметров тормозных жидкостей, с измерительным оборудованием и приборами;

провести подготовку тормозных жидкостей и оборудования к лабораторным испытаниям;

провести определение марки жидкости по цвету;

проверить тормозные жидкости на смешивание;

проверить образцы жидкости на растворимость в воде и бензине.

1.3. Оборудование и приборы: визуальная, органолептическая оценка параметров тормозных жидкостей.

1.4. Объект испытания: тормозные жидкости.

\section{5. Порядок выполнения работы}

Определение показателей тормозных жидкостей следует проводить в соответствии с техническими требованиями, например: тормозная жидкость ДОТ-4 (ТУ 2451-011-48318378-2004).

\section{Общие сведения}

Важной особенностью жидкостей для гидравлических тормозных приборов является то, что от их эксплуатационных качеств зависят не только долговечность и надежность работы деталей привода, но и безотказность работы тормозного механизма, т. е. безопасность движения автомобиля. 
Жидкость для гидравлического тормозного привода служит в качестве рабочей среды для передачи усилия от тормозной педали до тормозных колодок. При этом должны быть минимальные потери энергии на трение в приводе как на преодоление трения при передвижении жидкости в системе привода, так и на преодоление трения в подвижных его соединениях.

Безотказная работа тормозного механизма возможна при условии, что жидкость не будет терять текучесть при любых климатических условиях эксплуатации автомобиля и не будет нарушаться ее свойство несжимаемости, обеспечивающее плавную и полную передачу усилия.

Долговечность работы тормозного привода, затраты на его эксплуатацию зависят от химического воздействия на детали привода тормозной жидкости, а также от ее смазочных свойств, которые изменяются в зависимости от температуры.

Исходя из назначения и условий работы, жидкость для гидравлических тормозных приводов (тормозная жидкость) должна отвечать следующим эксплуатационно-техническим требованиям:

не должна вызывать коррозии металлических деталей, а также набухания, разъедания, высыхания резиновых манжет, клапанов и шлангов гидравлического привода;

обладать хорошими вязкостно-температурными свойствами, обеспечивая высокую подвижность (прокачиваемость) в зимнее время и отсутствие подтеканий в летнее время при колебаниях температур от $-50{ }^{\circ} \mathrm{C},-60^{\circ} \mathrm{C}$ (зимой в северных районах) до $100^{\circ} \mathrm{C}, 110^{\circ} \mathrm{C}$ (летом на южных горных дорогах);

иметь температуру кипения выше максимальной температуры нагрева жидкости в тормозном приводе (примерно $120 \ldots 130{ }^{\circ} \mathrm{C}$ ), чтобы не допускать образования паровых пробок в гидравлической системе и потерь жидкости от испарения;

обладать хорошими смазывающими свойствами для обеспечения минимальных износов трущихся деталей привода и минимальных потерь энергии на преодоление трения; 
быть стабильной, т. е. не расслаиваться, не выделять каких-либо осадков, не вспениваться и длительно при работе и хранении сохранять неизменными свои физико-химические свойства.

Для гидравлического привода тормозов автомобилей используют жидкости ГТЖ-22М, «Нева», «Томь», ДОТ-4.

Жидкость ГТЖ-22М состоит из 65 \% диэтиленгликоля, 32 \% этилкарбитола и 3 \% этилцеллозольва с добавлением антикоррозионных присадок. Жидкость всесезонная, окрашивается в зеленый или зелено-защитный цвет, хорошо растворима в воде, ядовита.

Жидкость «Нева» является композицией из $51 . .59$ \% этилкарбитола, $31 . .34 \%$ диолов, 5 \% эфиров карбитола и 13,5 \% смеси гликолей. В состав «Невы» входят загуститель и антикоррозионные присадки. Жидкость окрашена в желтый цвет, токсична, огнеопасна и растворяется в горячей воде.

Жидкости ГТМ-22М и «Нева» взаиморастворимы, имеют хорошие вязкостно-температурные свойства (прокачиваемость), низкую испаряемость. «Нева» рекомендуется для приводов тормозов современных автомобилей.

Всесезонная жидкость «Томь» представляет собой смесь гликолей и эфиров борной кислоты. Основные ее преимущества - меньшая гигроскопичность, незначительное снижение температуры кипения при обводнении, улучшенные противоизносные и антикоррозионные свойства. Эксплуатационные свойства жидкости обеспечивают надежную работу приводов тормозов грузовых и легковых автомобилей.

Смешение любой тормозной жидкости с топливом и маслами недопустимо, так как нефтепродукты разрушают резиновые детали, что приводит к отказам тормозной системы. Запрещено применение смесей спирта и глицерина или других веществ для тормозных систем.

На всех легковых и некоторых грузовых автомобилях тормозная система снабжена гидравлическим приводом. Надежность работы гидравлического привода зависит от эксплуатационных свойств тормозной жидкости. Тормозные жидкости должны быть легкоподвижными, обладать небольшой 
вязкостью; температура замерзания должна быть ниже температуры окружающего воздуха, при которой эксплуатируются автомобили. Жидкость не должна расслаиваться; не допускается выпадение сгустков и осадков. Тормозные жидкости должны обладать полной совместимостью с резиновыми деталями и металлом тормозной системы, а также хорошей смазывающей способностью. Выпускаются тормозные жидкости марок ГТЖ-22М, «Нева», БСК, ЭСК и т. п. (таблица 20).

Таблица 20 - Тормозные жидкости

\begin{tabular}{|c|c|c|c|}
\hline \multirow{2}{*}{ Показатель } & \multicolumn{3}{|c|}{ Норма для марки } \\
\hline & ГТЖ-22М & «Нева» & БСК \\
\hline Внешний вид & $\begin{array}{c}\text { Прозрачная } \\
\text { зеленая } \\
\text { жидкость }\end{array}$ & $\begin{array}{c}\text { Прозрачная жидкость } \\
\text { с цветом от желтого } \\
\text { до светло- } \\
\text { коричневого }\end{array}$ & $\begin{array}{c}\text { Жидкость с цветом от } \\
\text { красного до } \\
\text { оранжево-красного }\end{array}$ \\
\hline 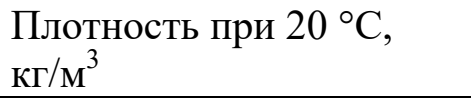 & $1100 \ldots 1110$ & $1012 \ldots 1015$ & $890 \ldots 900$ \\
\hline $\begin{array}{l}\text { Кинематическая вязкость } \\
\text { при температуре } 50{ }^{\circ} \mathrm{C}, \\
\mathrm{Mm}^{2} / \mathrm{c}(\mathrm{cC})\end{array}$ & $7,9 \ldots 8,3$ & Менее 5,0 & $9,4 \ldots 13,5$ \\
\hline $\begin{array}{l}\text { Низкотемпературные } \\
\text { свойства }\end{array}$ & $\begin{array}{c}\text { Температура } \\
\text { замерзания не } \\
\text { выше }-65^{\circ} \mathrm{C}\end{array}$ & $\begin{array}{c}\text { После выдержки } 6 \text { сут } \\
\text { при }-40 \text { } \mathrm{C} \text { и } 6 \text { ч при } \\
-50 \text { C не должно } \\
\text { быть расслаивания } \\
\text { или осадка }\end{array}$ & $\begin{array}{c}\text { При выдерживании в } \\
\text { течение } 30 \text { мин. при } \\
-40 \text { C не должно } \\
\text { быть расслаивания }\end{array}$ \\
\hline
\end{tabular}

Тормозная жидкость ГТЖ-22М представляет собой смесь различных гликолей (двухатомных спиртов). Она обладает удовлетворительными вязкостными и температурными, хорошими низкотемпературными свойствами (замерзает при температуре $-65{ }^{\circ} \mathrm{C}$ ), низкой испаряемостью и высокой температурой вспышки; не разрушает резиновые детали. К недостаткам тормозной жидкости ГТЖ-22М следует отнести сильную ядовитость, плохие смазывающие свойства и повышенную гигроскопичность.

Тормозная жидкость «Нева» на гликолевой основе наиболее распространена, она рекомендуется для большинства легковых автомобилей. Обладает хорошими вязкостно-температурными свойствами (вязкость при $50{ }^{\circ} \mathrm{C}$ не менее 5 сСт), хорошо растворяет воду, однородность водной смеси 
сохраняется до $-40{ }^{\circ} \mathrm{C}$ и ниже. Тормозная жидкость «Нева» огнеопасна, попадание ее на кожу человека приводит к дерматитам.

Тормозная жидкость БСК представляет собой смесь 50 \% касторового масла и 50 \% бутилового спирта.

Касторовое масло придает жидкости хорошую смазывающую способность. Жидкость не вызывает большого набухания или размягчения резиновых уплотнительных деталей тормозной системы. Тормозная жидкость БСК обладает неудовлетворительными вязкостно-температурными свойствами, поэтому ее рекомендуют применять только в средней полосе.

К недостаткам спиртокасторовой смеси относится высокая температура кристаллизации касторового масла (кристаллизация начинается при $5{ }^{\circ} \mathrm{C}$ и интенсивно протекает при $\left.-20{ }^{\circ} \mathrm{C}\right)$. В результате этого образуются сгустки, которые вызывают закупоривание трубопроводов гидравлического привода и отказ тормозов автомобиля. Применять жидкость БСК при температуре окружающего воздуха ниже $-20{ }^{\circ} \mathrm{C}$ не рекомендуется. Следует оберегать жидкость БСК от попадания воды, что может привести к расслоению жидкости.

Жидкость ЭСК представляет собой смесь 60 \% касторового масла и 40 \% этилового спирта, окрашенную в красный цвет.

Жидкость «Томь» представляет собой смесь гликолей и эфиров борной кислоты, применяется для гидравлических тормозов легковых и грузовых автомобилей. Обладает небольшой гигроскопичностью и хорошими противоизносными и антикоррозионными свойствами.

Нельзя смешивать тормозные жидкости, изготовленные на касторовой основе, с жидкостями на гликолевой основе, так как это приводит к ухудшению эксплуатационных качеств.

\section{Проведение испытаний}

Выполняют три определения.

Определение марки жидкости по цвету. Цвет тормозных жидкостей указан в таблице 13. 


\section{6. Подготовка объекта}

Проверка тормозных жидкостей на смешивание. Если марка гидравлической жидкости, залитой в тормозную систему, неизвестна, то делают пробу на смешивание.

\subsection{1. Методика определения}

В пробирку наливают равное количество жидкости, взятой из тормозной системы, и той, которую предполагается доливать в систему. Затем жидкости взбалтывают. Если произошло расслоение смеси, то жидкости изготовлены на разных основах, и доливать жидкость в тормозную систему нельзя.

Проверка образцов жидкости на растворимость в воде и бензине. При добавлении к жидкостям БСК и ЭСК воды они расслаиваются, а гликолевые жидкости полностью смешиваются с водой. При добавлении бензина к касторовой жидкости они полностью перемешиваются и образуют однородную смесь. Гликолевые жидкости не смешиваются с бензином, получаются два разнородных слоя.

\section{Контрольные вопросы и задания}

1. Перечислите эксплуатационные требования к тормозным жидкостям.

2. Каков состав тормозных жидкостей?

3. Назовите марки тормозных жидкостей, их особенности.

4. Какие сорта рекомендуют применять в различных климатических зонах?

5. В чем разница тормозных жидкостей БСК и «Роса ДОТ-4»? 


\section{Лабораторная работа №15 \\ КОНТРОЛЬ КАЧЕСТВА НЕФТЕПРОДУКТОВ \\ С ИСПОЛЬЗОВАНИЕМ ПОЛЕВЫХ ЛАБОРАТОРИЙ}

1.1. Цель работы: закрепить знания по устройству и функциям полевых лабораторий для контроля качества нефтепродуктов, приобрести навыки по оценке качественных параметров нефтепродуктов.

\section{2. Задачи работы:}

ознакомиться с методикой определения качества нефтепродуктов с использованием полевых лабораторий, с измерительным оборудованием и приборами;

провести подготовку нефтепродуктов и оборудования к лабораторным испытаниям;

провести измерения физико-химических показателей нефтепродуктов;

вычислить качественные параметры нефтепродуктов.

1.3. Оборудование и приборы: полевые лаборатории для контроля качества нефтепродуктов.

\section{4. Объект испытания - нефтепродукты.}

\section{5. Порядок выполнения работы}

Определение физико-химических, качественных параметров нефтепродуктов проводят в соответствии с требованиям действующих стандартов и технических условий

\section{Общие сведения}

Контроль качества топлива и смазочных материалов необходим для обеспечения надежной эксплуатации тракторов и автомобилей в течение длительного срока. Его проводят с целью определения соответствия физико- 
химических показателей нефтепродуктов требованиям действующих стандартов и технических условий; обнаружения некондиционных нефтепродуктов и своевременного исправления их качества; предупреждения ухудшения свойств нефтепродуктов при транспортировании и хранении; применения топлива и смазочных материалов рекомендованных сортов и в связи с этим своевременного проведения технического обслуживания сельскохозяйственной техники и автомобилей; предъявления претензий снабжающим организациям за поставку нефтепродуктов, не соответствующих стандартам или техническим условиям или не отвечающим требованиям по ассортименту.

Полевые средства контроля качества горючего (далее ПС ККГ) - это мобильные комплекты лабораторного оборудования, позволяющие проводить испытания горючего вне стационарной лаборатории, в полевых условиях.

Для контроля качества нефтепродуктов выпускают лаборатории ПЛ-2М, РЛ и ЭЛАН (таблицы 21 и 22).

Таблица 21 - Технические данные лабораторий

\begin{tabular}{|l|c|c|c|}
\hline \multicolumn{1}{|c|}{ Показатель } & \multicolumn{3}{c|}{ Название лаборатории } \\
\cline { 2 - 4 } & ПЛ-2М & РЛ & ЭЛАН \\
\hline Габариты, м: & & & \\
Длина & 726 & 625 & 560 \\
Ширина & 560 & 240 & 360 \\
Высота & 760 & 265 & 200 \\
Масса, кг & 111 & 14 & 15 \\
Время, мин, необходимое: & 90 & 5 & 5 \\
для развертывания лаборатории в рабочее положение & 45 & 5 & 5 \\
Для свертывания лаборатории & & & \\
\hline
\end{tabular}




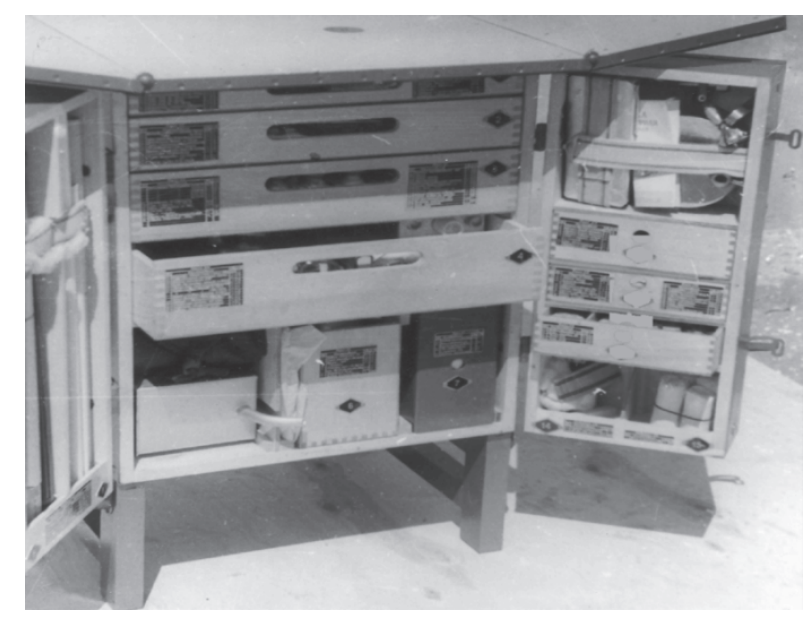

Рисунок 46 - Лаборатория ПЛ-2М в развернутом положении

Таблица 22 - Анализы, выполняемые при помощи лабораторий ПЛ-2М, РЛ и ЭЛАН

\begin{tabular}{|c|c|c|c|c|c|c|c|c|c|}
\hline \multirow{2}{*}{ Показатель } & \multicolumn{3}{|c|}{ Лаборатория ПЛ - 2М } & \multicolumn{3}{|c|}{ Лаборатория РЛ } & \multicolumn{3}{|c|}{ Лаборатория ЭЛАН } \\
\hline & топливо & масло & смазки & топливо & масло & смазки & топливо & масло & смазки \\
\hline $\begin{array}{l}\text { Плотность } \\
\text { (нефтеденсиметром) }\end{array}$ & + & + & - & + & + & - & + & + & - \\
\hline $\begin{array}{l}\text { Фракционный } \\
\text { состав } \\
\text { нефтепродуктов }\end{array}$ & + & - & - & - & - & - & - & - & - \\
\hline $\begin{array}{l}\text { Содержание } \\
\text { водорастворимых } \\
\text { кислот и щелочей } \\
\text { (качественно) }\end{array}$ & + & + & - & + & + & - & + & + & - \\
\hline Кислотность & + & + & - & - & - & - & + & + & - \\
\hline $\begin{array}{l}\text { Температура } \\
\text { застывания и } \\
\text { помутнения } \\
\end{array}$ & + & + & - & - & - & - & - & - & - \\
\hline $\begin{array}{l}\text { Кинематическая } \\
\text { вязкость }\end{array}$ & + & + & - & - & + & - & - & + & - \\
\hline $\begin{array}{l}\text { Температура } \\
\text { вспышки в } \\
\text { открытом тигле }\end{array}$ & + & + & - & - & - & - & - & - & - \\
\hline $\begin{array}{l}\text { Содержание воды } \\
\text { (количественно) }\end{array}$ & + & + & + & + & + & + & + & + & + \\
\hline $\begin{array}{l}\text { Содержание } \\
\text { механических } \\
\text { примесей } \\
\text { (качественно) }\end{array}$ & + & + & + & + & + & + & + & + & + \\
\hline $\begin{array}{l}\text { Температура } \\
\text { каплепадения }\end{array}$ & - & - & + & - & - & - & - & - & - \\
\hline
\end{tabular}

Примечание. "+" - анализ можно выполнить; "-" - анализ выполнить нельзя. 
Корпус лаборатории представляет собой деревянный ящик, на петлях которого навешены двухстворчатые дверцы. Корпус и дверцы разделены перегородками на 26 отделений, в которых размещено оборудование, входящее в комплект лаборатории. Все отделения пронумерованы, дан перечень помещенного в них имущества. Приборы, посуда и химические реактивы размещаются в гнездах и закреплены при помощи поясков, вертушек и других приспособлений. Для отбора проб нефтепродуктов лаборатория снабжена четырьмя пробоотборниками, позволяющими отбирать пробы топлива и смазочных материалов из мелкой тары и светлых нефтепродуктов - из резервуаров и из цистерн. Для приведения лаборатории ПЛ-2М в рабочее положение в отведенном помещении ее устанавливают на ножки, раскрывают дверцы корпуса и крышки стола, проверяют горизонтальность стола, вынимают необходимые приборы и реактивы и размещают их на столе.

Лаборатория ПЛ-2М размещается в помещении, пригодном для проведения лабораторных работ, с хорошей освещенностью и наличием достаточной площадки для оборудования рабочих мест, а также в помещении обеспеченном водой, электроэнергией и оборудованном вентиляцией. В полевых условиях они могут быть развернуты в необорудованном (без вентиляции) помещении, землянке или палатке. В этом случае вместо водопровода рекомендуется использовать водяной бак, вместо принудительной вентиляции - достаточно эффективную - естественную.

Для приведения лаборатории ПЛ-2М в рабочее положение необходимо: установить ее в месте, удобном для работы в данных условиях;

снять чехол и замок;

откинуть ножки корпуса и закрепить их (ножки должны плотно стоять на полу помещения);

верхнюю крышку корпуса разложить в виде рабочего стола, раскрыть боковые створки;

вынуть из ящиков (отделений) необходимые для анализа приборы, посуду и реактивы, подготовить и разместить на рабочем столе. 
Для сборки приборов с использованием стержней штативов на поверхности стола имеются резьбовые пробки. Приборы и реактивы, не требующиеся для проведения данного анализа, должны находиться в соответствующих ящиках и отделениях.

При проведении анализов в стационарных условиях приборы и лабораторная посуда могут размещаться на лабораторных столах или в вытяжных шкафах стационарных лабораторий.

Анализ горючего, масел, смазок и специальных жидкостей в лабораториях ПЛ-2М проводится в соответствии с требованиями стандартов на методы испытаний.

\section{Ручная лаборатория РЛ}

Лаборатория РЛ (рисунок 47) помещается в деревянном ящике с откидной крышкой. Все оборудование находится в специальных гнездах и закреплено поясками и вертушками. Нефтеденсиметры и гидрометр размещены в откидном штативе, дно которого может быть использовано в качестве столика. Лаборатория позволяет замерять толщину слоя нефтепродуктов в резервуарах и отбирать пробы.

Лаборатория РЛ может быть развернута в помещении, палатке, под навесом или в другом укрытии, защищенном от ветра и атмосферных осадков. Для приведения лаборатории в рабочее положение надо открыть крышку ящика, откинуть штатив с нефтеденсиметрами, вынуть и разместить на рабочем месте необходимые приборы и реактивы.

В комплект лаборатории РЛ входит лот (рисунок 47), который служит для взятия проб из резервуаров, цистерн и других крупных емкостей. При отборе пробы зажимают верхний конец резиновой трубки 5 и при помощи рулетки 4 опускают лот в цистерну на необходимую глубину. После этого резиновую трубку разжимают, и нефтепродукт заполняет стакан 7. Пробоотборник извлекают из цистерны, отвинчивают крышку 6 и выливают пробу топлива в чистую посуду. Для определения высоты слоя воды, находящегося на дне резервуара, на линейку 1 наносят тонкий слой водочувствительной пасты или 
прикрепляют к ней водочувствительную бумагу. Пробоотборник опускают в цистерну и устанавливают его на дне. Затем извлекают пробоотборник и по измененному цвету пасты или бумаги на линейке определяют толщину слоя воды.
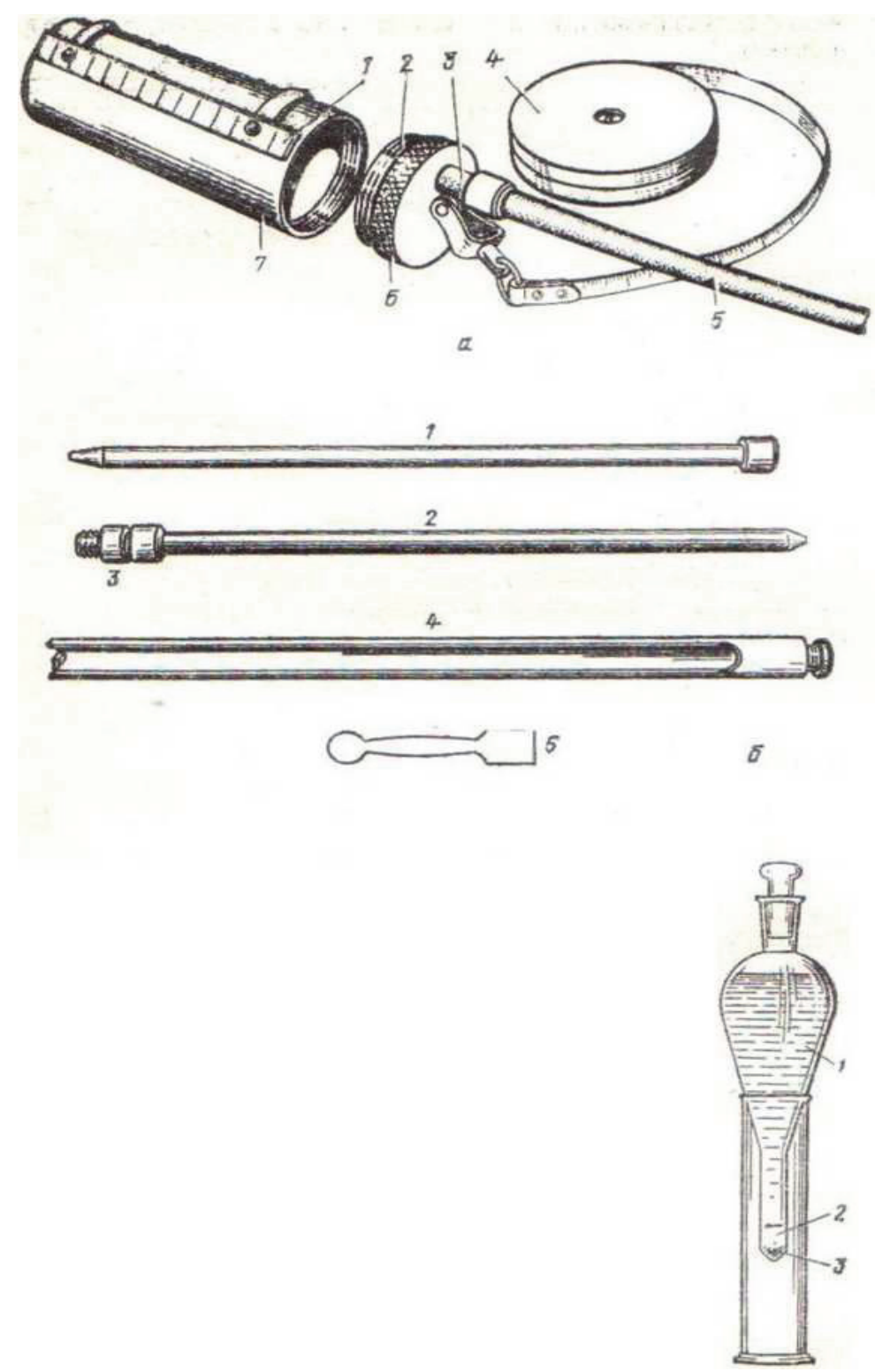

Рисунок 47 - Оборудование лаборатории РЛ: а - лот с рулеткой для отбора проб топлива: 1 - линейка; 2 - резьба; 3 - штуцер; 4 - рулетка; 5 - резиновая трубка; 6 - крышка; 7 - стакан; б - пробоотборники: 1, 2, 4 - трубки соответственно для отбора топлива, масла, смазок; 3 - переходник; 5 - лопатка; в - отстойник: 1 - топливо; 2 - вода; 3 - механические примеси 
Для отбора проб из мелкой тары предназначены пробоотборники (рисунок 47, б), которые размещены на внутренней стороне крышки лаборатории. При помощи алюминиевой трубки 1 отбирают топливо, трубкой 2, которая с помощью переходника 3 соединяется с верхней частью пробоотборника, отбирают масла. Пластичные смазки берут с помощью пробоотборника 4, лопатку 5 вставляют в пробоотборник и сдвигают пластичную смазку в банку.

В лаборатории присутствует марганцовокислый калий, с помощью которого определяют наличие воды на дне емкости. Это вещество не растворяется в нефтепродуктах, но легко растворяется в воде. Несколько кристаллов марганцовокислого калия заворачивают в белую ткань, затем опускают пакетик на дно емкости и выдерживают там 3...4 мин. Появление малинового окрашивания ткани указывает на наличие воды на дне резервуара.

Для определения содержания механических примесей и воды в ручной лаборатории имеется стеклянный отстойник (рисунок 47, в). Вместимость отстойника - 100 мл, в нижней части он переходит в узкую трубку, которая отградуирована до 10 мл через 0,05 мл (по этим делениям определяют количество воды и механических примесей), далее идут деления 25, 50 и 100 мл. Исследуемое топливо тщательно перемешивают, быстро наливают в отстойник до уровня 100 мл и выдерживают в отстойнике 25 мин. Отстойник должен находиться в вертикальном положении. Затем определяют количество механических примесей и воды в процентах, которое равно объему отстоя каждого компонента в миллилитрах.

Примеси в маслах осаждаются медленно, поэтому масла разбавляют бензином. Пробу масла наливают в отстойник до уровня 25 или 50 мл, а до 100 мл добавляют бензин, не содержащий механических примесей. Смесь тщательно перемешивают, и отстойник опускают в теплую воду. После отстаивания находят процентное содержание механических примесей и воды.

Ручная лаборатория снабжена также и другими приспособлениями и реактивами для определения качества нефтепродуктов простейшими способами. 
Механические примеси и воду можно обнаружить в топливе, просматривая образец в пробирке из бесцветного стекла. Если в топливе присутствует вода во взвешенном состоянии, то топливо во всем объеме пробирки мутное. Капля масла, содержащая воду и нанесенная на стекло, в проходящем свете мутная.

Наличие влаги в масле можно определить пробой на потрескивание. Для этих целей 2...3 мл тщательно перемешанного масла наливают в пробирку, которую осторожно нагревают. При наличии воды слышно слабое потрескивание, масло пенится, на верхней холодной части пробирки конденсируются капельки воды.

Присутствие абразивных механических примесей в маслах определяют пробой на истирание. На плоское чистое стекло наносят одну-две капли испытуемого масла и закрывают вторым стеклом. Затем передвигают стекла одно относительно другого, плотно прижав их пальцами. Если в масле присутствуют абразивные механические примеси, слышен характерный резкий скрип.

Количество смол в топливе определяют так. Берут пипеткой 1 мл бензина, помещают его на сферическое стекло и поджигают. Если исследуют дизельное топливо, то к этому количеству добавляют столько же бензина, не содержащего смол. После сгорания топлива на стекле остаются желтые или коричневые кольца. Чем больше смол содержится в испытуемом топливе, тем темнее остаток и больше диаметр пятна. По диаметру пятна определяют содержание смолистых соединений в топливе (таблица 23).

Таблица 23 - Содержание смолистых соединений в топливе

\begin{tabular}{|l|c|c|c|c|c|c|c|c|c|c|}
\hline Диаметр пятна, мм & 6 & 8 & 10 & 12 & 14 & 16 & 18 & 20 & 22 & 24 \\
\hline Количество смол, мг/100 мл & 4 & 11 & 20 & 32 & 43 & 56 & 70 & 85 & 102 & 120 \\
\hline
\end{tabular}

Если в топливе смолы отсутствуют, то на стекле остается небольшое белое малозаметное пятно. При наличии в топливе масляных загрязнений на краю стекла остаются коричневые капли. 
Для определения содержания непредельных углеводородов в пробирку наливают небольшое количество исследуемого топлива и такое же количество водного раствора марганцовокислого калия, розового цвета. Содержимое пробирки перемешивают и дают отстояться водному слою. Если розовый цвет изменится на желтый, то в топливе присутствуют непредельные углеводороды, которые способствуют быстрому окислению топлива, увеличению содержания смол и кислот. Такое топливо нестабильно, не пригодно к длительному хранению, его надо быстрее использовать.

Для определения плотности нефтепродуктов лаборатория РЛ снабжена нефтеденсиметрами, для определения температуры застывания низкозамерзающих охлаждающих жидкостей (антифризов) - гидрометром, для определения кинематической вязкости масел - полевым вискозиметром. В комплект входят также реактивы и посуда для определения водорастворимых кислот и щелочей.

\section{Экспресс-лаборатория анализа нефтепродуктов ЭЛАН}

Экспресс-лаборатория предназначается для оценки качества топлива и смазочных материалов в условиях эксплуатации, хранения и транспортирования.

Лаборатория представляет собой набор приборов, приспособления, химической посуды, реактивов и материалов, размещенных на полках и стенках футляра-шкафчика.

Определение кислотного числа масел основано на взаимодействии органических кислот, извлеченных из масла этиловым спиртом, с едким кали в присутствии индикатора нитрозинового желтого. В измерительный цилиндр с притертой пробкой наливают 25 мл спиртового раствора индикатора нитрозинового желтого. При помощи пипетки с резиновым баллончиком в измерительный цилиндр наливают испытуемое масло в количестве, определяемом по таблице 24, в зависимости от максимально допустимого кислотного числа, установленного для данного масла по ГОСТу. 
Таблица 24 - Объем масла, отбираемого для определения кислотного числа

\begin{tabular}{|c|c|c|c|}
\hline $\begin{array}{c}\text { Кислотное число } \\
\text { масла по ГОСТ, мг } \\
\text { КОН/г }\end{array}$ & $\begin{array}{c}\text { Кислотное число } \\
\text { масла по ГОСТ, мг } \\
\text { КОН/г }\end{array}$ & Объем масла, мл \\
\hline 0,04 & 46 & 0,25 & 7 \\
\hline 0,05 & 36 & 0,30 & 6 \\
\hline 0,07 & 26 & 0,35 & 5 \\
\hline 0,10 & 13 & 0,50 & 3 \\
\hline 0,14 & 14 & 0,75 & 2 \\
\hline 0,15 & 12 & 1,00 & 1 \\
\hline 0,20 & 9 & 2,00 & \\
\hline 0,22 & 8 & & \\
\hline
\end{tabular}

Зеленая или синяя окраска спиртового слоя указывает на то, что кислотное число масла не превышает установленного предела.

Желтая окраска спиртового слоя указывает на то, что кислотное число масла превышает допустимую норму.

Определение механических примесей в работавших маслах основано на нанесении капли масла на фильтровальную бумагу и сравнении полученных после воздушной сушки пятен с эталоном.

Пробоотборник 10 заполняют не более чем на $3 / 4$ объема и перемешивают масло встряхиванием в течение 5 мин. Затем пипеткой 13 с резиновым баллончиком берут масло и одну каплю наносят на фильтровальную бумагу. Высушенная капля образует пятно, которое сравнивают с эталоном масляных пятен (таблица 25).

Таблица 25 - К определению механических примесей в масле

\begin{tabular}{|c|l|c|}
\hline № эталона & \multicolumn{1}{|c|}{ Внешний вид пятна } & $\begin{array}{c}\text { Содержание механических } \\
\text { примесей, \% }\end{array}$ \\
\hline 1 & Светлое желтоватое пятно & $0,00 \ldots 0,01$ \\
\hline 2 & $\begin{array}{l}\text { Желтоватое пятно с резко ограниченной } \\
\text { более темной окантовкой }\end{array}$ & $0,01 \ldots 0,05$ \\
\hline 3 & $\begin{array}{l}\text { Серое пятно, ограниченное еще более } \\
\text { темной окантовкой }\end{array}$ & $0,05 \ldots 0,10$ \\
\hline 4 & $\begin{array}{l}\text { Темно-серое пятно, ограниченное черной } \\
\text { окантовкой }\end{array}$ & $0,10 \ldots 0,80$ \\
\hline 5 & Сплошное черное пятно & 0,8 и более \\
\hline
\end{tabular}




\section{Определение кинематической вязкости вискозиметром СЭВ-1}

основано на сравнении скорости погружения стального шарика в испытуемом масле со скоростью погружения таких же шариков в эталонные масла с известной вязкостью.

Вискозиметр оборудован девятью стеклянными пробирками, восемь из которых заполнены маслами с определенной вязкостью (таблица 26).

Таблица 26 - Вязкость эталонных масел, приведенная к $100^{\circ}$ и $50{ }^{\circ} \mathrm{C}$

\begin{tabular}{|c|c|c|c|c|c|}
\hline \multirow{2}{*}{ № пробирок } & \multicolumn{2}{|c|}{ Вязкость, $\mathrm{Mм}^{2} / \mathrm{c}(\mathrm{cС})$} & \multirow{2}{*}{ № пробирок } & \multicolumn{2}{c|}{ Вязкость, $\mathrm{MM}^{2} / \mathrm{c}(\mathrm{cСт})$} \\
\cline { 2 - 3 } \cline { 5 - 6 } & при $100{ }^{\circ} \mathrm{C}$ & при $50{ }^{\circ} \mathrm{C}$ & & при $100{ }^{\circ} \mathrm{C}$ & при $50{ }^{\circ} \mathrm{C}$ \\
\hline 1 & 4 & 14 & 5 & 16 & 108 \\
\hline 2 & 7 & 35 & 6 & 18 & 128 \\
\hline 3 & 10 & 54 & 7 & 20 & 150 \\
\hline 4 & 13 & 82 & 8 & 22 & 171 \\
\hline
\end{tabular}

\section{6. Подготовка объекта}

В заполненные пробирки с эталонными маслами помещено по одному шарику. Девятая пробирка пустая, на ней нанесены две метки. В эту пробирку наливают до нижней метки испытуемое масло, опускают в него шарик и закрывают резиновой пробкой, которая должна входить в пробирку до верхней метки. Далее пробирку вставляют в свободное гнездо вискозиметра и закрепляют ее пробкой с флажком. Размер воздушного пузырька в пробирке должен быть равен размерам пузырьков в пробирках с эталонными маслами. Его регулируют положением пробки. Вискозиметр выдерживают при окружающей температуре 10 мин. Устанавливают вискозиметр в вертикальное положение (пробками вверх) и дают всем шарикам опуститься на дно, после чего вискозиметр резко поворачивают на 180. Шарики во всех пробирках начинают опускаться. Как только шарик в пробирке с испытуемым маслом достигнет риски, нанесенной на раму вискозиметра, прибор поворачивают на $90^{\circ}$ вокруг горизонтальной оси.

Вязкость испытуемого масла находят сравнением положения шариков в испытуемом и эталонных маслах. 


\subsection{1. Методика определения}

Определение содержания воды в нефтепродуктах основано на ее взаимодействии с гидридом кальция. Реакция проходит с выделением тепла. По повышению температуры испытуемого нефтепродукта после добавления к нему гидрида кальция определяют содержание воды.

В стеклянный цилиндр 18 наливают до метки 10 мл топлива, затем цилиндр вставляют в термостат 17. Термометр 15 опускают в цилиндр и измеряют начальную температуру нефтепродукта. Высыпают в цилиндр 0,7 г гидрида кальция. Термометром осторожно размешивают содержимое цилиндра и отмечают максимальную температуру пробы.

\subsection{2. Обработка результатов измерений}

Подсчитывают разность температур нефтепродукта и определяют содержание (\%) воды в нефтепродукте.

\section{Контрольные вопросы и задания}

1. Назовите основные виды потерь нефтепродуктов.

2. С какой целью проводят контроль качества нефтепродуктов?

3. Каким образом осуществляют экспресс-контроль качества нефтепродуктов?

4. Какие полевые лаборатории используют?

5. Какие виды проверок выполняют для масел, бензинов? 


\section{СПИСОК ЛИТЕРАТУРЫ}

1. Кузнецов А. В. Топливо и смазочные материалы. - М.: КолосС, 2004. - 199 c.

2. Кузнецов А. В., Кульчев М. А. Практикум по топливу и смазочным материалам.- М. : Агропромиздат, 1987. - 224 с.

3. Топлива, смазочные материалы, технические жидкости. Ассортимент и применение: Справочное издание / Под ред. В. М. Школьникова. - М. : Техинформ, 1999. - 596 с.

4. Стуканов В. А. Автомобильные эксплуатационные материалы: Учебное пособие. Лабораторный практикум. - М. : ИД «ФОРУМ»: ИНФРА-М, 2006. -208 c.

5. Сафонов А. С., Ушаков А. И., Гришин В. В. Химмотология горючесмазочных материалов.- СПб.: НПИКЦ, 2007 - 488 с.

6. Сафонов А.С., Ушаков А.И., Орешенков А.В. Качество автомобильных топлив. - СПб. : НПИКЦ, 2006- 394 с.

7. Сафонов А. С., Ушаков А. И., Чечкенев И. В. Автомобильные топлива. Химмотология. Эксплуатационные свойства. Ассортимент.- СПб. : НПИКЦ, 2002 - 262 с.

8. Анализ качества горючего: Методическое пособие (авторский коллектив).- М., 2008. - 695 с.

9. Данилов А. М. Введение в химмотологию. - М. : Техника, 2003.$464 \mathrm{c}$.

10. Гуреев А. А., Азев В. С., Камфер Г. М. Топливо для дизелей. Свойства и применение. - М. : Химия, 1993. - 336 с.

11. Гуреев А. А., Азев В. С. Автомобильные бензины, свойства и применение.- М. : Нефть и газ, 1996. - 442 с.

12. Данилов А. М. Применение присадок в топливах для автомобилей. - М. : Химия, 2000. - 232 с. 
13. Ранд С. ДЖ. (ред.) Анализ нефтепродуктов. Методы, их назначение и определение.- СПб. : Профессия, 2012. - 663 с.

14. Горючие смазочные материалы: Энциклопедический толковый словарь-справочник / под ред. В. М. Школьникова. - М. : Изд. центр «Техинформ» Международной академии стандартизации, 2007. - 735 с. 


\section{СОДЕРЖАНИЕ}

Введение.

Лабораторная работа № 1. Определение теплоты сгорания дизельного топлива...

Лабораторная работа № 2. Исследование состава продуктов сгорания автомобильного бензина.

Лабораторная работа № 3. Исследование фракционного состава автомобильного бензина.

Лабораторная работа № 4. Определение низкотемпертурных свойств дизельного топлива

Лабораторная работа № 5. Определение цетанового числа дизельного топлива по совпадению вспышек.

Лабораторная работа № 6. Определение температуры вспышки.

Лабораторная работа № 7. Определение кинематической вязкости нефтепродукта.

Лабораторная работа № 8. Определение вязкостно-температурных свойств моторного масла..

Лабораторная работа № 9. Определение предела прочности на сдвиг пластичной смазки.

Лабораторная работа № 10. Определение пенетрации пластичной смазки.

Лабораторная работа № 11. Определение коллоидной стабильности пластичной смазки.

Лабораторная работа № 12 . Определение плотности нефтепродуктов.

Лабораторная работа № 13. Исследование качества низкозамерзающих охлаждающих жидкостей 
Лабораторная работа № 14. Исследование качества тормозных

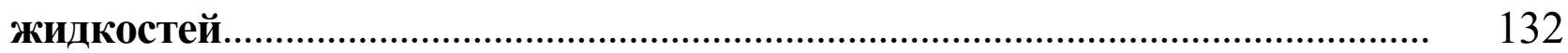

Лабораторная работа № 15. Контроль качества нефтепродуктов с помощью полевых лабораторий.................................................................. 138

Список литературы............................................................................................. 150 
Дидманидзе Отари Назирович

Улюкина Елена Анатольевна

Пильщиков Владимир Львович

Пуляев Николай Николаевич

Приваленко Алексей Николаевич

\section{ЛАБОРАТОРНЫЙ ПРАКТИКУМ:}

\section{топливо и смазочные материалы}

Компьютерная верстка Н. Т. Бзишвили

Подписано в печать 16.05.2016

Формат 60x84/16

Бумага офсетная

Заказ № 470
Усл. печ. л. 8,95

Тираж 500 экз.

Печать трафаретная

Цена договорная

Отпечатано в ООО «УМЦ «Триада»

127550, Москва, ул. Лиственничная аллея, д. 7, корп. 2

www.tverdyy-pereplet.ru 